\title{
HYDROLOGY OF THE HART SYNCLINE AREA, NORTHWESTERN COLORADO
}

By William P. Van Liew and S. G. Robson

U.S. GEOLOGICAL SURVEY

Water-Resources Investigations Report 92-4050

Prepared in cooperation with the

U.S. BUREAU OF LAND MANAGEMENT and MOFFAT COUNTY 


\title{
U.S. DEPARTMENT OF THE INTERIOR \\ BRUCE BABBITT, Secretary
}

\author{
U.S. GEOLOGICAL SURVEY
}

Dallas L. Peck, Director

For additional information write to:

District Chief

U.S. Geological Survey

Box 25046, Mail Stop 415

Federal Center

Denver, CO 80225-0046
Copies of this report can

be purchased from:

U.S. Geological Survey

Books and Open-File Reports Section Box 25425

Federal Center

Denver, CO 80225-0425 
Abstract-10

Introduction-

Page

Purpose and scope-1

Physical setting-

Geology-

Methods of study-

Previous investigations-C.

Acknowledgments-

Hydrogeologic framework-

Definition of aquifers-

Areal extent of aquifers-

Ground water

Recharge to bedrock aquifers

Flow through bedrock aquifers-

Discharge from bedrock aquifers-

Hydraulic characteristics of bedrock aquifers-

Hydraulic head-1

Transmissivity-10

Storage--

Hydraulic characteristics of valley-fill aquifers-_... Hydraulic head-a

Transmissivity-1.

Surface water-

Streamflow

Suspended-sediment discharge--

Water quality-

Ground water-

Bedrock aquifers-

Valley-fill aquifers-_-

Springs-1

Surface water-

Need for additional studies-10 Summary-

Selected references-10

Supplemental information-

Well-completion diagrams and generalized geologic logs for wells

completed in bedrock aquifers

Water-level hydrographs for wells completed in bedrock aquifers----

Water-level hydrographs for wells completed in valley-fill aquifers-

Analyses of aquifer tests

Site HS85-34-

Well HS85-20A2-

Site HS85-17-

We11 HS85-20-2-

Water-quality data-

Plate 1. Map showing data-collection sites and geologic and hydrologic features in the Hart Syncline area, northwestern Colorado- 
Figure 1. Map showing location of the Hart Syncline area-_age

2. Map showing location of coal-bearing formations in northwestern Colorado- 5

3. Generalized stratigraphic sections in coal-bearing areas of northwestern Colorado-.... 6

4. Diagram showing relation of lithologic and hydrogeologic units in the Hart Syncline area- 10

5. Map showing structure contours of the top of the Trout Creek Sandstone-.... 12

6. Map showing structure contours of the bottom of the Yampa bed 13

7. Generalized hydrogeologic section showing postulated direction of ground-water flow- 14

8. Map showing potentiometric surface in the lower part of the Williams Fork Formation-16

9. Graph showing cumulative change in main-stem discharge along Deep Rock Gulch, August 28 and October 16, 1986-_...- 19

10. Graph showing cumulative change in main-stem discharge along Waddle Creek, August 27, 1986-10 20

11. Generalized sections showing relation of Waddle Creek valley to geologic structure--

12. Water-level hydrographs for wells completed in the upper coal aquifer, lower coal aquifer, and Trout Creek aquifer at site HS85-1-.

13. Water-level hydrographs for wells completed in the upper coal aquifer, lower coal aquifer, and Trout Creek aquifer at site HS85-17--.-.

14. Map showing approximate area where wells completed in the upper coal aquifer can be expected to flow at land surface-

15. Generalized hydrogeologic section showing potentiometric surface in the upper coal aquifer-

16. Hydrogeologic sections through the valley fill in the valley of Deep Rock Gulch: (A) Section B-B', upstream from the streamflow-gaging station 09249455; and (B) Section C-C', at streamflow-gaging station 09249455, Deep Rock Gulch near Hamilton--

17. Hydrogeologic sections through the valley fill in the valley of Waddle Creek: (A) Section D-D', upstream from the streamflow-gaging station 09249450; and (B) Section E-E', at streamflow-gaging station 09249450, Waddle Creek near

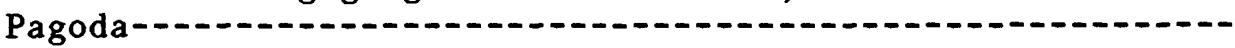

18. Water-level hydrographs for wells completed in the valleyfill aquifer along Deep Rock Gulch-

19. Water-level hydrographs for wells completed in the valleyfill aquifer along Waddle Creek-1

20. Graph showing relation between instantaneous suspendedsediment discharge and stream discharge for Deep Rock Gulch near Hamilton (09249455), January 8 to October 7, 1986-.-.-

21. Graph showing relation between instantaneous suspendedsediment discharge and stream discharge for Waddle Creek near Pagoda (09249450), January 8 to October 7, 1986-....- 
Figures 22-25. Trilinear diagrams showing:

Page

22. Major-ion composition of water from bedrock aquifers-............. 40

23. Major-ion composition of water from valley-fill aquifers--.-.-.- 42

24. Major-ion composition of water from springs--.---- 44

25. Major-ion composition of surface-water samples----- 45

26-34. Diagrams showing:

26. Well completion and generalized geologic $\log$ for borehole HS85-1--.- 53

27. Well completion and generalized geologic $\log$ for borehole HS85-15c-_-_. 54

28. Well completion and generalized geologic $\log$ for boreholes HS85-16 and HS85-16c---n 55

29. Well completion and generalized geologic $\log$ for boreholes HS85-17 and HS85-17c-_ 56

30. Well completion and generalized geologic log for boreholes HS85-20 and HS85-20A-_-_- 57

31. Well completion and generalized geologic log for borehole HS85-22c-1 58

32. Well completion and generalized geologic log for boreholes HS85-34 and HS85-34c--- 59

33. Well completion and generalized geologic $\log$ for boreholes HS85-35 and HS85-35c-- 60

34. Well completion and generalized geologic 108 for borehole HS85-38c-_ 61

35. Water-level hydrographs for wells completed in bedrock

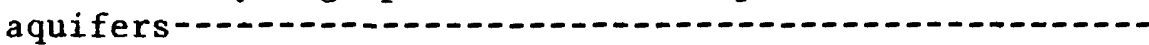

36. Water-level hydrographs for wells completed in valley-

fill aquifers-....... 3 55

37-43. Graphs showing:

37. Water-level changes in wells during test pumping of well HS85-34c4, July 27 to 28, 1986-.......-

38. Fluctuations in pumping rate during test pumping of well HS85-34c4, July 27 to 28, 1986-_.....- 80

39. Results of aquifer test using observation well HS85-34-1, July 27 to $28,1986-\ldots 1$

40. Results of flowing-well aquifer test using well HS85-20A2, July 23 to August 9, 1986-_-...-.

41. Water-level changes in wells during test pumping of well HS85-17-4, August 12 to 13, 1986-......-

42. Fluctuations in pumping rate during test pumping of we11 HS85-17-4, August 12 to 13, 1986-.....-

43. Results of slug test using well HS85-20-2, December 12, 1986- 
Table 1. Summary of gain-and-loss investigations in Deep Rock Gulch and Waddle Creek-18

2. Summary of hydraulic coefficients of bedrock aquifers obtained from analyses of aquifer tests 28

3. Streamflow data for gaging stations in the Hart Syncline area for the 1986 water year- 35

4. Water-quality standards for selected characteristics and constituents- 39

5. Water-quality data for bedrock wells- 88

6. Water-quality data for valley-fill wells

7. Water-quality data for springs-ar 92

8. Water-quality data for surface-water sites-- 95

\section{CONVERSION FACTORS AND VERTICAL DATUM}

\section{Multiply}

acre-foot (acre-ft)

cubic foot per second $\left(\mathrm{ft}^{3} / \mathrm{s}\right)$

foot $(\mathrm{ft})$

foot per day ( $\mathrm{ft} / \mathrm{d}$ )

foot squared per day $\left(\mathrm{ft}^{2} / \mathrm{d}\right)$

(gallon per day) per foot $[(\mathrm{gal} / \mathrm{d}) / \mathrm{ft}]$

gallon per minute (gal/min)

inch (in.)

mile (mi)

square mile $\left(\mathrm{mi}^{2}\right)$

ton per year (ton/yr)
By

1,233

0.28317

0.3048

0.3048

0.09290

0.69489

0.06308

25.40

1.609

2.590

0.9072

To obtain

cubic meter

cubic meter per second meter

meter per day

meter squared per day

(cubic meter per day) per meter

liter per second

millimeter

kilometer

square kilometer

metric ton or megagram

per year

Temperature in degree Fahrenheit $\left({ }^{\circ} \mathrm{F}\right)$ may be converted to degree Celsius $\left({ }^{\circ} \mathrm{C}\right)$ by use of the following equation:

$$
{ }^{\circ} \mathrm{C}=5 / 9\left({ }^{\circ} \mathrm{F}-32\right) \text {. }
$$

Temperature in degree Celsius $\left({ }^{\circ} \mathrm{C}\right)$ may be converted to degree Fahrenheit $\left({ }^{\circ} \mathrm{F}\right)$ by use of the following equation:

$$
{ }^{\circ} \mathrm{F}=9 / 5\left({ }^{\circ} \mathrm{C}\right)+32 .
$$

Sea level: In this report, "sea level" refers to the National Geodetic Vertical Datum of 1929--a geodetic datum derived from a general adjustment of the first-order level nets of the United States and Canada, formerly called Sea Level Datum of 1929. 
HYDROLOGY OF THE HART SYNCLINE AREA, NORTHWESTERN COLORADO

By William P. Van Liew and S.G. Robson

\begin{abstract}
The Hart Syncline area, located about 15 miles south of the town of Craig in northwestern Colorado, is underlain by Federal coal reserves. A study to define the hydrology of the area prior to development of the coal resources was done from April 1985 through September 1987.

The Hart Syncline is the prominent structural feature of the area. The uppermost 50 to 150 feet of the Iles Formation of Upper Cretaceous age is the water-bearing Trout Creek Sandstone Member, which constitutes the Trout Creek aquifer. The Upper Cretaceous Williams Fork Formation overlies the Iles Formation and consists of fractured coal beds interbedded with claystone, mudstone, siltstone, and very fine-grained to fine-grained sandstone. Groundwater flow in the Williams Fork Formation is mainly in the fractured coal beds and sandstone; the interbedded fine-grained rocks probably act as confining units. About 150 to 200 feet above the base of the Williams Fork Formation is a laterally continuous, 2- to 3-foot layer of argillaceous volcanic ash, called the Yampa bed, which acts as a confining unit. The interbedded coal and fine-grained rocks underlying the Yampa bed compose the lower Williams Fork coal aquifer. Above the Yampa bed are about 150 to 250 feet of interbedded coal and fine-grained rocks, which compose the upper Williams Fork coal aquifer. Above these aquifers in the Williams Fork Formation are about 600 feet of interbedded fine-grained rocks that contain several tens of feet of sandstone. These sandstone beds are water bearing in places but are not continuous throughout the Hart Syncline area.
\end{abstract}

Recharge to the bedrock aquifers occurs locally from infiltration of precipitation on outcrops of the Trout Creek Sandstone Member and the Williams Fork Formation. Flow in bedrock aquifers is principally down dip along bedding planes from recharge areas near the margins of the syncline toward discharge areas near the larger valleys at the western, northern, and eastern margins of the syncline. The bedrock aquifers probably discharge to springs and diffuse seeps in the valleys.

Transmissivity and hydraulic conductivity of the bedrock aquifers were determined from four aquifer tests. Transmissivity ranged from 0.5 to 9 feet squared per day and the hydraulic conductivity ranged from 0.005 to 0.6 foot per day. The values of hydraulic conductivity of fractured coal and fractured sandstone media are about 100 times that of the Trout Creek aquifer, in which ground-water flow occurs interstitially. The total volume of recoverable water in storage in the bedrock aquifers in the Hart Syncline area is about 0.5 million acre-feet. 
Deep Rock Gulch and Waddle Creek are gaining streams at the location of several monitoring wells completed in the valley fill. The hydraulic conductivity of the valley-fill aquifer in the valley of Deep Rock Gulch is about 0.1 to 1 foot per day and the transmissivity is about 1 to 10 feet squared per day. The hydraulic conductivity of the valley-fill aquifer in the valley of Waddle Creek is about 0.2 to 5 feet per day and the transmissivity is about 5 to 100 feet squared per day.

Water in the areally continuous bedrock aquifers was a calcium bicarbonate type or a calcium magnesium bicarbonate type near the recharge areas, and a sodium bicarbonate type at locations further along the ground-water flow path. Water in local sandstone units in the upper Williams Fork Formation was a calcium bicarbonate type or a calcium sulfate type. Dissolved-solids concentrations for all bedrock-aquifer samples averaged about 830 milligrams per liter.

\section{INTRODUCTION}

The Hart Syncline area of northwestern Colorado is located in mountainous terrain about $15 \mathrm{mi}$ south of Craig, Colorado (fig. 1). The $21 \mathrm{mi}^{2}$ area contains extensive deposits of coal in rocks of the Upper Cretaceous Mesaverde Group. Private land in the area is underlain by Federal coal reserves. The U.S. Bureau of Land Management, as part of its responsiblity for managing these coal resources, issued a coal-exploration license to the Getty Mining Company $^{1}$ (Getty) in 1983 so that Getty could assay the coal resource and estimate the suitability of the area for mining. As part of an effort to define the hydrology and to determine the potential environmental effect of additional coal development, the U.S. Geological Survey, in cooperation with the U.S. Bureau of Land Management and Moffat County, conducted a hydrologic study from April 1985 through September 1987 to describe the hydrology of the Hart Syncline area prior to development of the coal resources.

\section{Purpose and Scope}

This report presents: (1) A description of the hydrogeologic framework of the area, including the identification and location of the bedrock aquifers; (2) a determination of the hydraulic characteristics and ground-water flow system of the bedrock aquifer system; (3) an assessment of surface-water discharge and suspended-sediment discharge from selected streams in the area; and (4) a description of the chemical quality of the ground water, springs, and surface water in the area.

\footnotetext{
${ }^{1}$ The use of industry or firm names in this report is for identification or location purposes only, and does not impute responsibility for any present or potential effects on the natural resources.
} 


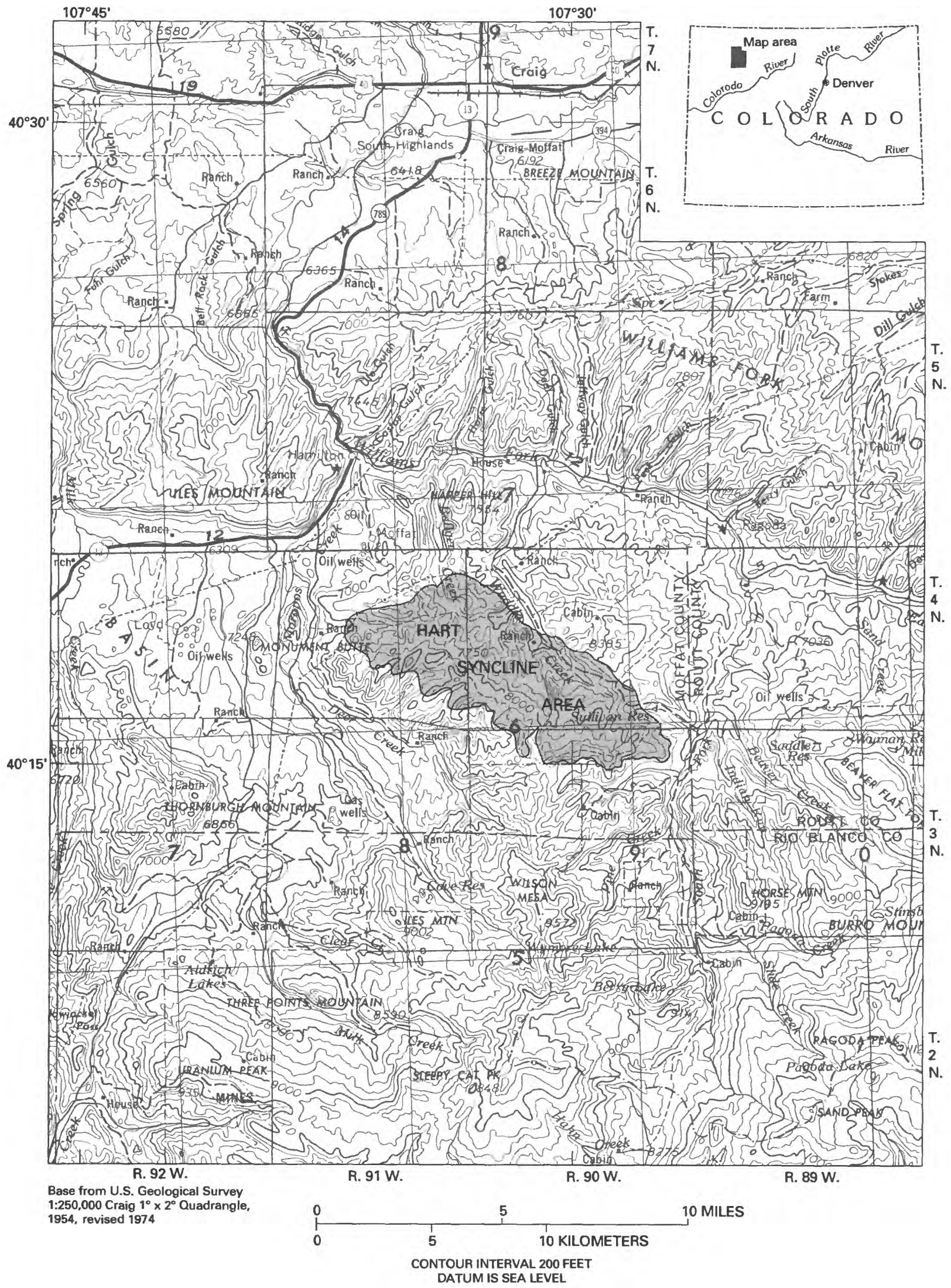

Figure 1.--Location of the Hart Syncline area. 


\section{Physical Setting}

The Hart Syncline area is located in the southern part of the Wyoming Basin physiographic province and is part of an extensive area underlain by coal-bearing formations in northwestern Colorado (fig. 2). Land surface altitudes range from about 7,000 to about $8,600 \mathrm{ft}$ in the Hart Syncline area. The topography is characterized mostly by north-sloping hillsides cut by deeply incised alluvial valleys. Slopes are covered with aspen, scrub oak, and coniferous trees at higher altitudes and sage brush and grasses at lower altitudes. Waddle Creek (plate 1) drains the northeastern part of the Hart Syncline area and has a drainage area of $22.0 \mathrm{mi}^{2}$. Deep Rock Gulch and Hart Gulch are its principal tributaries. Deer Creek drains the southwestern part of the Hart Syncline area and has a drainage area of $29.1 \mathrm{mi}^{2}$. Moody Gulch is a tributary drainage to Deer Creek. Badger Creek drains some of the northern part of the area and has a drainage area of $4.6 \mathrm{mi}^{2}$. Cedar Creek and Coal Creek drain the extreme southeastern part of the Hart Syncline area.

The Hart Syncline area receives about 16 to 25 in. of precipitation per year (Colorado State University, 1984), much of which is snow. More precipitation falls in the higher altitudes and southeastern parts of the area than in the valleys and northwestern parts.

\section{$\underline{\text { Geology }}$}

Principal water-yielding and coal-bearing formations in the area are contained in the Upper Cretaceous Mesaverde Group. The prominent structural feature of the area, the Hart Syncline (plate 1), has formed an elongate asymetrical basin in which rocks of the Mesaverde Group crop out. The Upper Cretaceous Mancos Shale, which underlies the study area, is about 4,900 ft thick and consists primarily of homogeneous dark-gray marine shale (Bass and others, 1955). The Mesaverde Group overlies the Mancos Shale and consists of the Iles Formation and the Williams Fork Formation in this western part of the Yampa coal field (fig. 3). The Iles Formation is about 1,500 ft thick in the area and consists mainly of interbedded very fine-grained to fine-grained sandstone, siltstone, shale, and coal (the lower coal group). The upper 50 to $150 \mathrm{ft}$ of the Iles Formation is a fine-grained, white, cliff-forming sandstone known as the Trout Creek Sandstone Member. The Williams Fork Formation overlies the Trout Creek Sandstone Member of the Iles Fomation. The basal unit of the Williams Fork Formation is the middle coal group, about 1,000 ft of interbedded very fine-grained to fine-grained sandstone, siltstone, shale, and coal. Overlying the middle coal group is about 100 to $200 \mathrm{ft}$ of the white, cliff-forming Twentymile Sandstone Member of the Williams Fork Formation. Above the Twentymile Sandstone Member are the interbedded sandstone, sandy shale, shale, and coal (the upper coal group) of the upper part of the Williams Fork Formation.

The Upper Cretaceous Lewis Shale overlies the Williams Fork Formation in much of northwestern Colorado. However, in the Hart Syncline area, the Lewis Shale and most of the underlying upper coal group of the Williams Fork Formation have been removed by erosion. The Twentymile Sandstone Member is present only in some of the north-central part of the area. Consequently, the investigation described in this report focused on the stratigraphic interval from the Trout Creek Sandstone Member of the Iles Formation through the middle coal group of the Williams Fork Formation (fig. 3). 


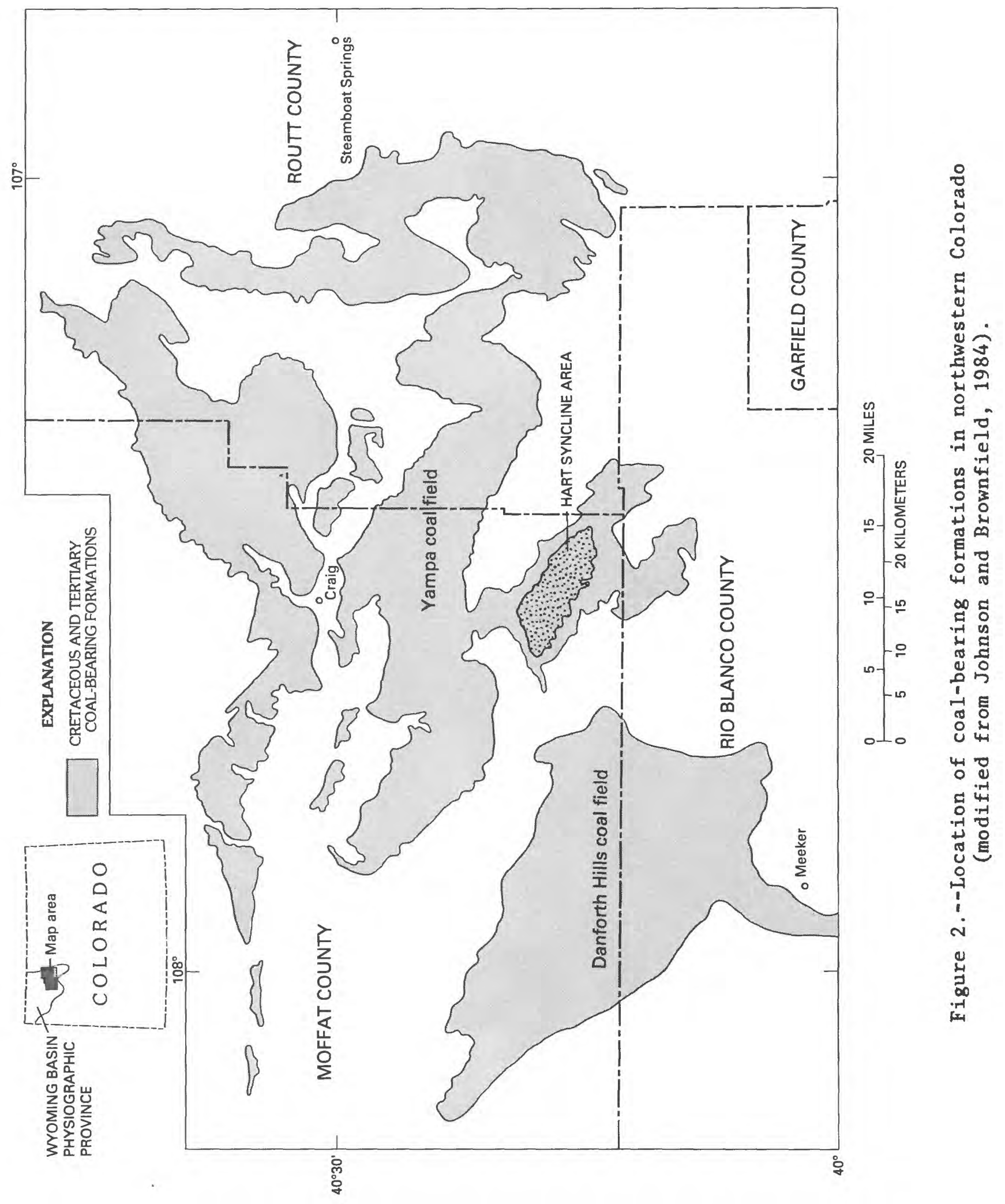




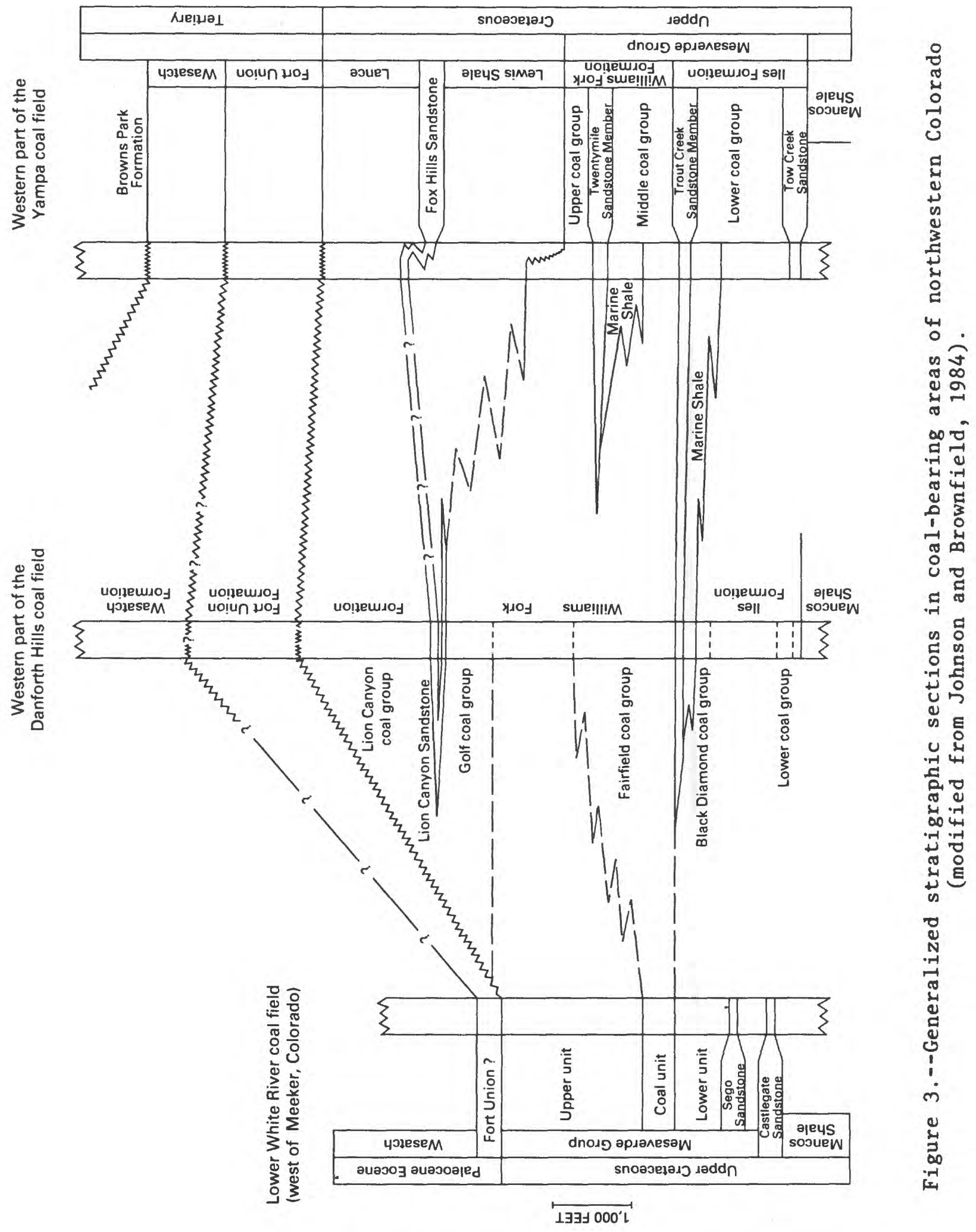


Unconsolidated valley-fill material is present in the larger valleys and is composed of colluvium and alluvium. Colluvium consists of unsorted to poorly sorted clay, silt, fine sand, and coal fragments. Angular to subangular coarse sand, gravel, and cobble-sized fragments of fine sandstone also are present. Alluvium consists of clay, silt, and poorly to moderately sorted subangular to rounded sand, gravel, and cobbles, most of which are composed of fine sandstone.

\section{Methods of Study}

In the summer and fall of 1985, U.S. Geological Survey personnel completed selected coal-exploratory test holes drilled by Getty as hydrologic observation wells. Consequently, the installation of hydrologic observation wells completed in bedrock aquifers was limited to locations, both in areal and vertical extent, where coal-exploratory test holes were drilled. Furthermore, the locations at which these test holes were drilled by Getty in 1985 were limited to areas that needed additional definition of the coal resources. Getty had drilled other coal-exploratory test holes in the summers of 1983 and 1984, and focused their 1985 drilling efforts only in specific parts of the study area. Consequently, in much of the area, no hydrologic observation wells have been constructed, and little data on water levels, water chemical quality, and hydraulic properties of the bedrock aquifers are available. During September and October 1985, 12 monitoring wells completed in the valley-fill materials and 2 streamflow-gaging stations were installed in the valleys of Waddle Creek and Deep Rock Gulch. Data were collected from these sites from October 1985 to December 1986. The interpretations contained in this report are based on these data, analysis of data from the available bedrock observation wells, data from springs and streams, and interpretations based on the geologic setting.

A hydrologic monitoring network, consisting of 26 bedrock-aquifer monitoring wells in 14 boreholes (many have multiple completions) at 9 sites, 12 monitoring wells in valley fill, and 2 continuous streamflow-gaging stations, was installed during August and September 1985 (pl. 1). Wellcompletion diagrams and generalized geologic logs for each of the 14 boreholes that penetrate bedrock aquifers are shown in the "Supplemental Information" section at the back of this report (figs. 26-34).

Stream discharge and water levels in observation wells were measured monthly from October 1985 through December 1986. During the summer of 1986, water samples were collected from bedrock wells, valley-fill wells, springs, seeps, and selected sites on streams for laboratory analysis of dissolved and selected total chemical constituents. Also during 1986, aquifer tests were done on several wells completed in bedrock aquifers and on wells completed in valley-fill aquifers. Gain-and-loss investigations were done along Deep Rock Gulch in August and October 1986 and along Waddle Creek in August 1986 to help determine the interaction between ground water and surface water. The data collected during these investigations were used in conjunction with qualitative observations from onsite visits to conceptualize the ground-water flow system. 


\section{Previous Investigations}

The coal resources in the Hart Syncline area have been studied since the early 1900's; however, there has been little study of the water resources in this area until this investigation. Hancock (1925) presented results of a regional investigation of the geology and coal resources of the Axial and Monument Butte quadrangles (west of the study area). Bass and others (1955) did a regional study of the geology and mineral fuels in parts of Routt and Moffat Counties. During 1976, 1977, and 1978, 37 exploratory test holes were drilled in the Hart Syncline area by the U.S. Geological Survey to assay the coal resources in the area. Geophysical logs of these test holes and a short text describing the drilling program have been published by Meyer $(1977,1978)$ and Meyer and Brown (1982). However, none of these studies discussed the water resources of the Hart Syncline area.

Giles and Brogden (1978) reported the results of hydrologic datacollection activities undertaken by the U.S. Geological Survey in the Yampa River basin and in parts of the White River basin during 1974 through 1976. As part of their data report, five domestic wells and one spring in the Hart Syncline area were inventoried. At one of these wells, which is completed in the Iles Formation, water samples were collected for laboratory analysis of dissolved constituents. No surface-water data were collected in the Hart Syncline area as part of their study. Maura (1982, 1985) presented waterquality data collected by the U.S. Geological Survey for streams in the southern Yampa River basin, including one site on Waddle Creek downstream from the present study area.

\section{Acknowledgments}

The authors thank the Getty Mining Company, now Cyprus Coal Company, for allowing the U.S. Geological Survey the opportunity to complete selected coalexploratory test holes drilled by Getty as hydrologic observation wells, the Consolidation Coal Company for allowing the U.S. Geological Survey to have access to their land to do this study, and the U.S. Bureau of Land Management for providing lithologic information about past coal-exploration activities in the Hart Syncline area.

\section{HYDROGEOLOGIC FRAMEWORK}

Sedimentary rocks in the Hart Syncline area are permeable because of primary porosity in sandstone and secondary porosity in fractured sandstone or coal. Shale, mudstone, and unfractured coal are relatively impermeable and form the principal confining units.

\section{Definition of Aquifers}

The Mancos Shale, a 4,900-ft-thick marine shale, is assumed to be impermeable and forms the base of the aquifer system in the Hart Syncline area (fig. 4). The overlying Iles Formation, which consists of interbedded very fine-grained to fine-grained sandstone, siltstone, shale, and coal beds, may 
contain aquifers and confining units but is poorly defined by data in this area. The Trout Creek Sandstone Member is the uppermost 50 to $150 \mathrm{ft}$ of the Iles Formation and consists of a relatively homogeneous, clean, very fine grained to fine-grained sandstone. Although no test holes were drilled more than $20 \mathrm{ft}$ into the Trout Creek Sandstone as part of this study, the sandstone was water bearing wherever it was penetrated and thus is defined as the Trout Creek aquifer (fig. 4). A carbonaceous shale layer in the basal Williams Fork Formation overlies the Trout Creek aquifer and may act as an overlying confining unit for the aquifer.

Above the Iles Formation is a sequence of coal beds and interbedded finegrained deposits that extend through the lower 300 to $450 \mathrm{ft}$ of the Williams Fork Formation. Individual coal beds within this sequence are not continuous; they may pinch out or may thicken laterally, or thicker coal beds may separate into several thinner beds. Thus, individual coal beds were not defined as individual aquifers in the lower 300 to $450 \mathrm{ft}$ of the Williams Fork Formation, even though most ground-water flow in this interval likely occurs in these fractured coal beds (Robson and Stewart, 1990). Rather, the entire interval is defined here as two aquifers separated by a confining unit. The Yampa bed of Brownfield and Johnson (1986) is the confining unit. The Yampa bed is located 150 to $200 \mathrm{ft}$ above the base of the Williams Fork Formation and consists of a laterally continuous, 2- to 3-ft-thick layer of argillaceous volcanic ash (fig. 4). That part of the Williams Fork Formation below the Yampa bed, consisting of coal beds and interbedded fine-grained deposits, is defined as the lower Williams Fork coal aquifer, hereinafter referred to as the lower coal aquifer. That part of the Williams Fork Formation from the Yampa bed to the top of the sequence of coal beds, also consisting of coal beds and interbedded fine-grained deposits, is defined as the upper Williams Fork coal aquifer, hereinafter referred to as the upper coal aquifer. The upper limit of the upper coal aquifer is not well defined because the coal beds become thinner and occur less commonly nearer the top of the aquifer.

Above this sequence of coal beds in the Williams Fork Formation are about $600 \mathrm{ft}$ of interbedded mudstone, siltstone, several tens of feet of very fine grained to fine-grained sandstone, and one or two coal beds. Although these rocks generally form a confining unit, in some areas, some of the sandstones yield water and form local aquifers.

The Twentymile Sandstone Member of the Williams Fork Formation overlies this 600-ft-thick sequence of deposits in high, local areas near the center of the syncline and consists of a 100- to 200-ft-thick layer of permeable rock (Robson and Stewart, 1990) that may contain local aquifers. Rocks located above the Twentymile Sandstone Member are present only in local areas and likely do not contain aquifers.

Unconsolidated valley-fill material in the principal stream valleys also contains aquifers. These valley-fill aquifers primarily are composed of silt, sand, and gravel and may be confined locally by overlying and underlying beds of clay. The better sorted and more coarse-grained alluvium is more permeable than the poorly sorted colluvium. 


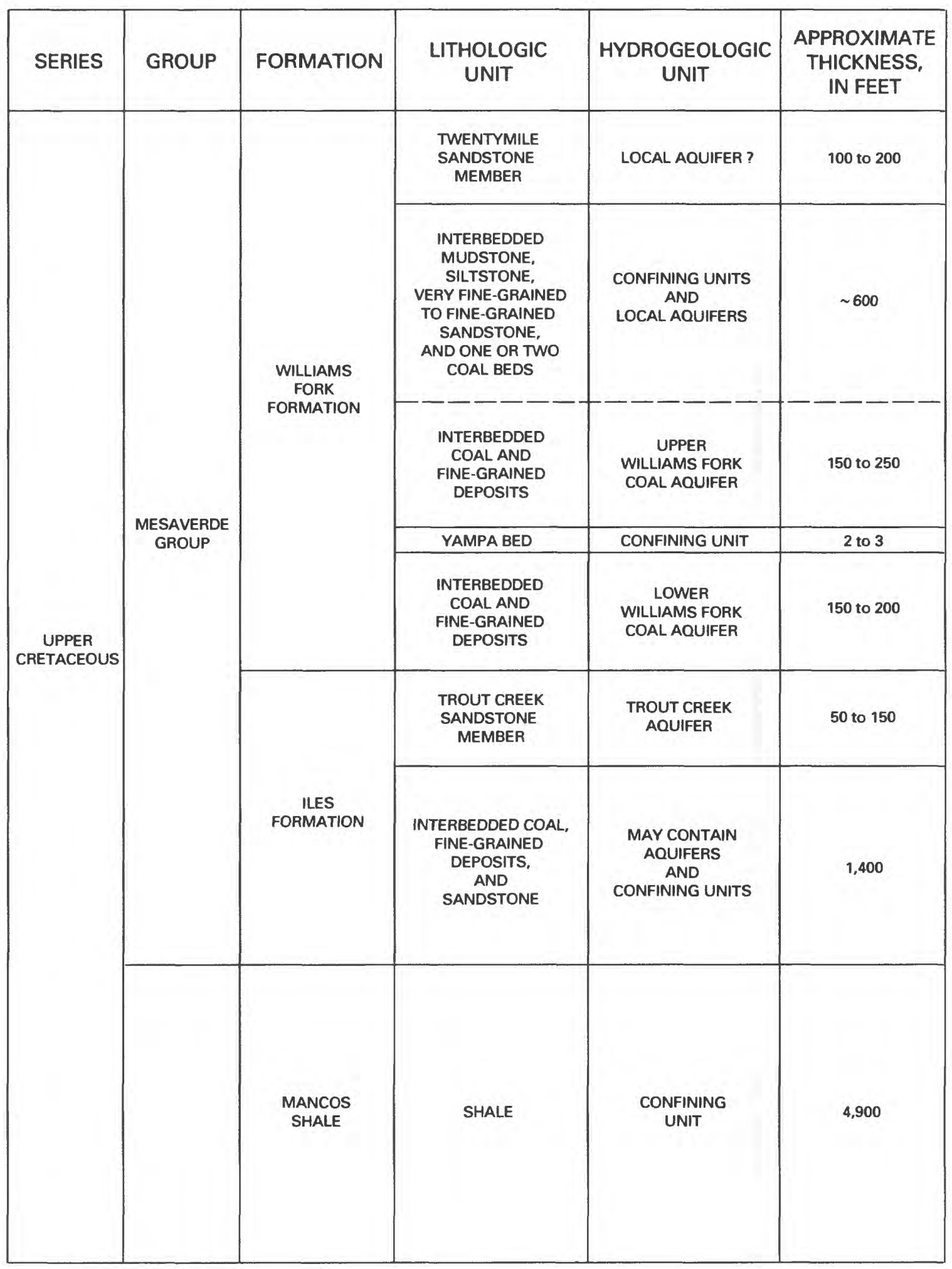

Figure 4.--Relation of lithologic and hydrogeologic units in the Hart Syncline area. 


\section{Areal Extent of Aquifers}

Structure contours of the top of the Trout Creek Sandstone (fig. 5) and the bottom of the Yampa bed (fig. 6) indicate the approximate altitude, shape, and distribution of the top of the Trout Creek aquifer, the bottom and top of

the lower coal aquifer, and the bottom of the upper coal aquifer. The contours also indicate the general shape of the structural basin. The line identified on figures 5 and 6 as the boundary of the Williams Fork Formation also is the approximate limit of the Trout Creek aquifer. Except where eroded near the Williams Fork boundary, the Trout Creek aquifer, the lower coal aquifer, and the upper coal aquifer are continuous throughout the area within the boundary.

Much of the Williams Fork Formation above the upper coal aquifer has been eroded. The two sandstone units that form local aquifers above the coal aquifers in the Williams Fork Formation are present only in the northwestern part of the study area and on ridges between the incised stream valleys elsewhere in the study area. The local aquifer in the Twentymile Sandstone Member of the Williams Fork Formation is present near the center of the structural basin (secs. 13 and 24, T. 4 N., R. 91 W.) and may extend to the high cliffs between the valleys of Deep Rock Gulch and Waddle Creek (secs. 28 and 29, T. 4 N., R. 90 W.). The valley-fill aquifers extend along the valleys of the larger streams in the area and generally are 100 to $200 \mathrm{ft}$ wide.

\section{GROUND WATER}

Data needed to define the ground-water hydrology of the bedrock aquifers in the Hart Syncline area are not numerous or well distributed. However, more extensive data and hydrologic interpretations are available (Robson and Stewart, 1990) for other coal aquifers of the Yampa coal field in an area extending from about 5 to $30 \mathrm{mi}$ northeast of the Hart Syncline. Similarities in geology, structure, hydrology, topography, and climate between the two areas enable evaluation of the hydrology of the Hart Syncline area based on sparse local data and hydrologic processes identified in the nearby area.

\section{Recharge to Bedrock Aquifers}

Most recharge to the bedrock aquifers in the Hart Syncline area is by infiltration of snowmelt and rainfall. Two mechanisms for infiltration are likely: (1) Water infiltrates into the dipping aquifers along their topographically high surface exposures at the margins of the basin, from which ground water flows primarily down dip along bedding planes; and (2) water directly recharges the aquifers on the primarily north-facing outcrops of the Williams Fork Formation by percolation through the upper, fine-grained rocks, and across bedding planes (fig. 7). The first mechanism of recharge has a more permeable path for water movement into the aquifer; however, the second mechanism for recharge has a larger surface area available for recharge. 


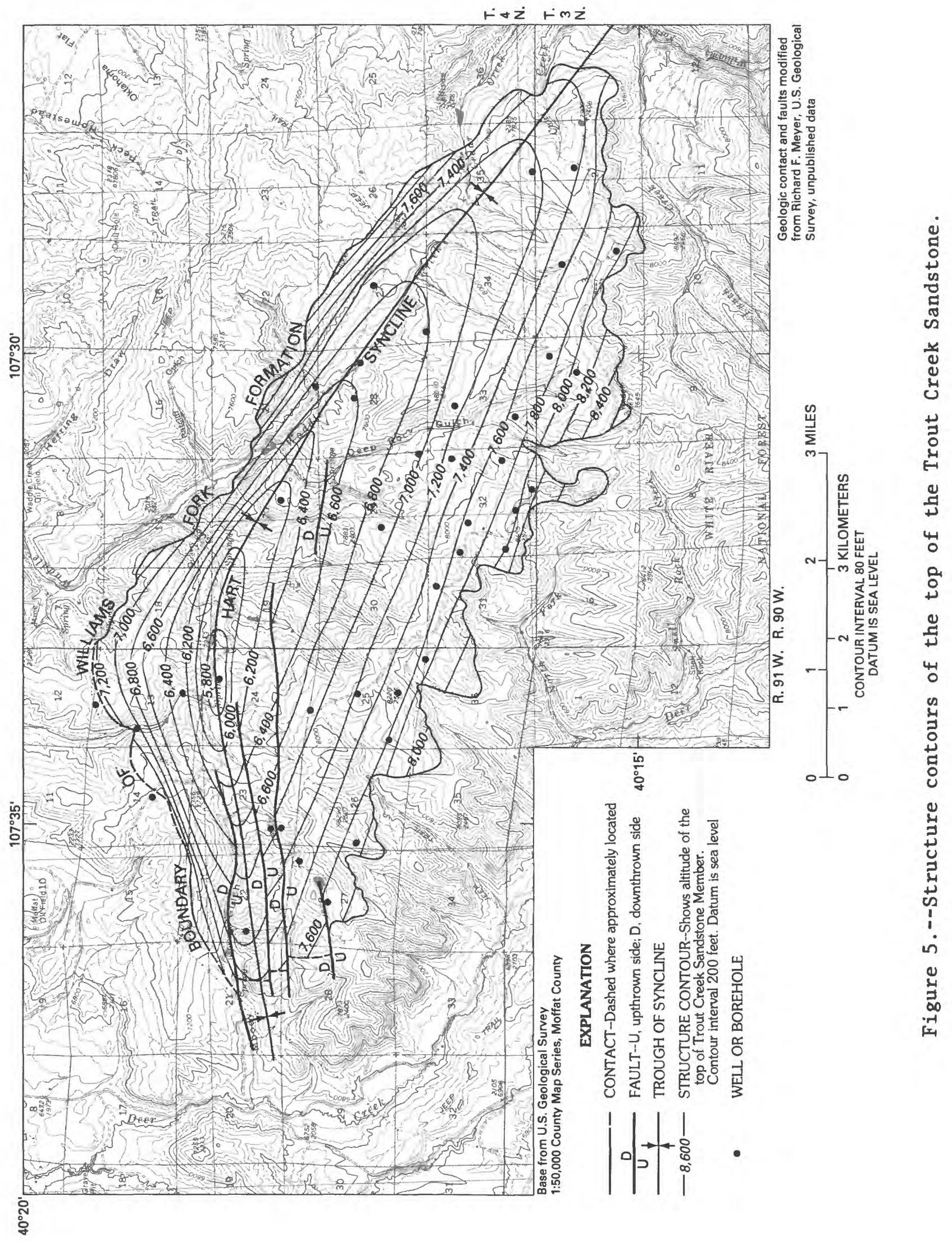




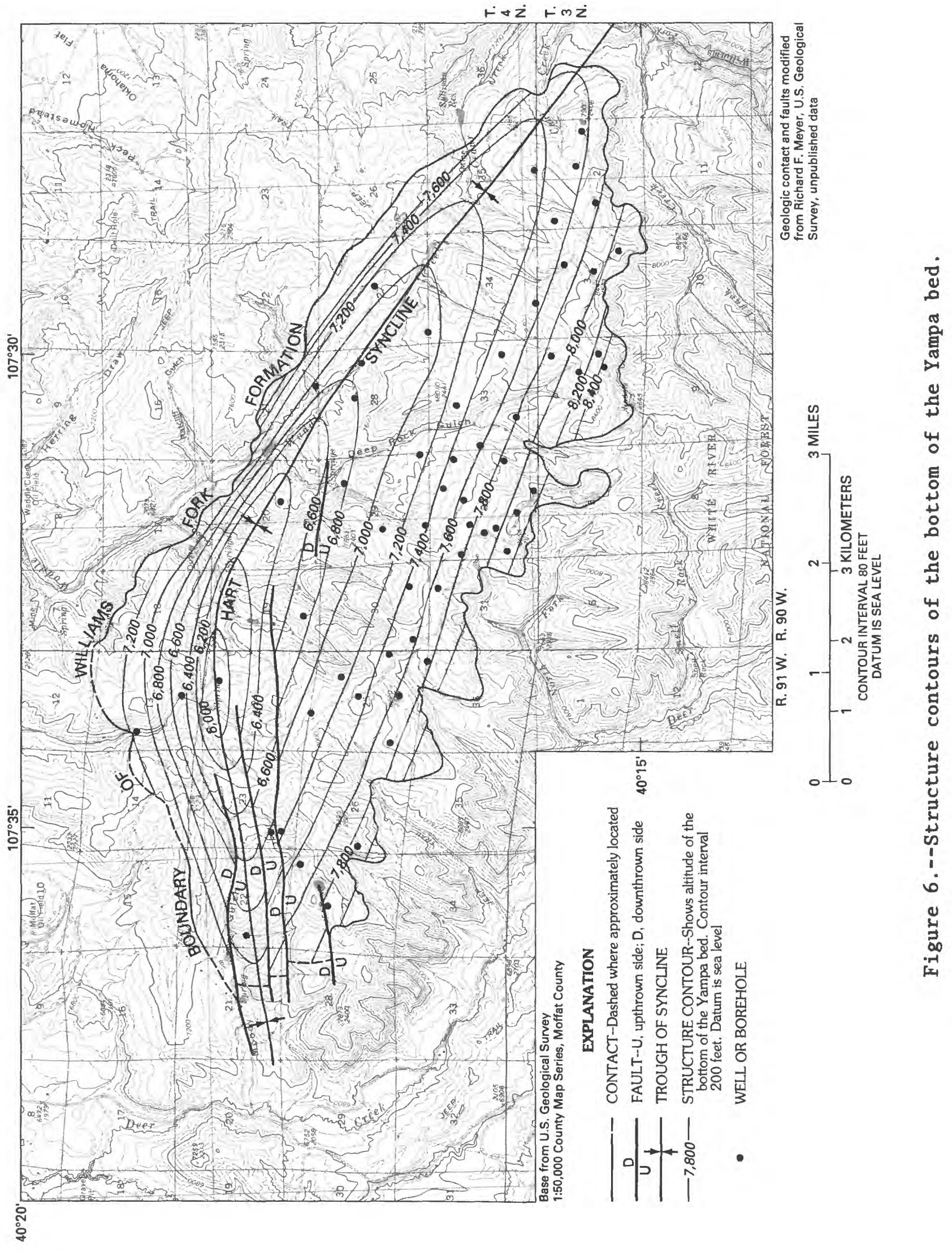




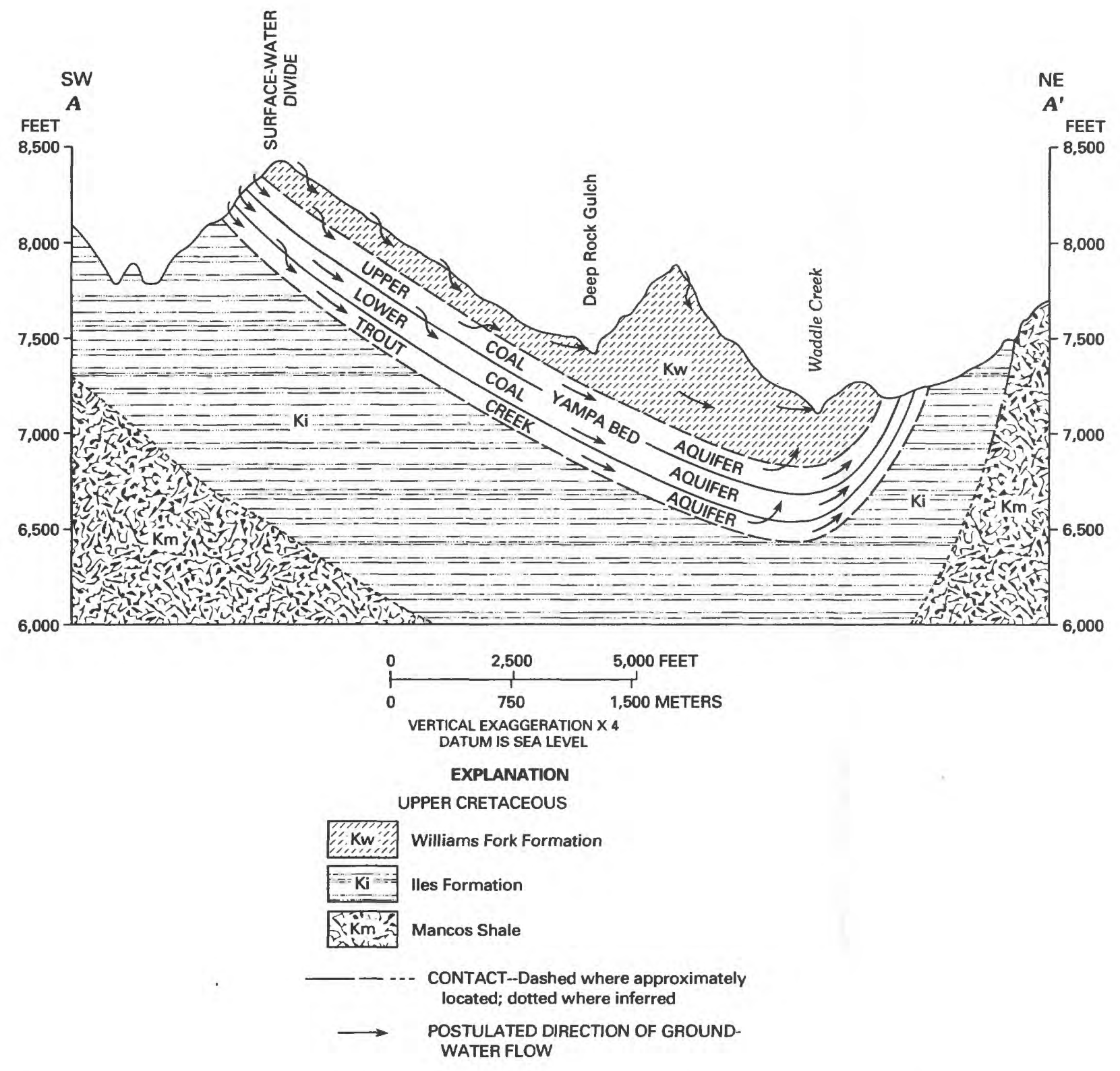

Figure 7.--Generalized hydrogeologic section showing postulated direction of ground-water flow (trace of section shown on plate 1 ). 
Aquifers above the Yampa bed, including the upper coal aquifer and overlying local sandstone aquifers, probably receive most of their recharge by direct recharge and percolation across bedding planes. Rocks that contain these aquifers crop out over most of the Hart Syncline area, and even small rates of infiltration over the large exposure can result in significant recharge.

The lower coal aquifer and the Trout Creek aquifer probably receive much of their recharge by down-dip movement of water from the outcrops near the higher margins of the syncline. Greater precipitation and longer periods of snowmelt likely enable greater recharge in these higher altitude parts of the basin. Thickness of the rocks overlying the aquifers increases toward the axis of the syncline and recharge across bedding planes is restricted by the increasing number of confining units between the surface and the aquifers.

\section{Flow Through Bedrock Aquifers}

Data are insufficient to define the potentiometric surface in individual aquifers. However, water-level data from wells drilled-into the lower part of the Williams Fork Formation can be used to approximate the water-level altitude in this part of the formation. The surface defined by these data (fig. 8) is of similar slope to that defined near the few wells completed in individual aquifers, and the surface likely indicates the general configuration of the potentiometric surfaces in the individual aquifers. Water-level data for piezometers at three sites (fig. 8) indicate that heads in the lower coal aquifer are approximately equal to the average of the heads in the upper coal aquifer and the Trout Creek aquifer. Head differences between the upper coal aquifer and the Trout Creek aquifer are about 50, 130 , and $260 \mathrm{ft}$ at the three sites. Heads are lower in the Trout Creek aquifer than in the upper coal aquifer at these sites. This head relation is common in recharge areas of stratified coal aquifers (Robson and Stewart, 1990). Heads probably are higher in the Trout Creek aquifer than in the upper coal aquifer near discharge areas, although no data are available to define this relation in the Hart Syncline area.

Most ground-water flow in the sandstone and fractured coal of the bedrock aquifers likely is along bedding planes rather than transverse to them (fig. 7). The general direction of flow is to the north, down the dip of the beds toward the trough of the Hart Syncline, and then toward discharge areas in valleys near the northwest and southeast ends of the syncline or to discharge areas near the northern margins of the Williams Fork Formation (fig. 8).

Ground-water flow in the upper part of the Williams Fork Formation, including the two water-bearing sandstone units, probably also is generally to the north. However, not enough water-level data exist to define the potentiometric surface for these aquifers. 


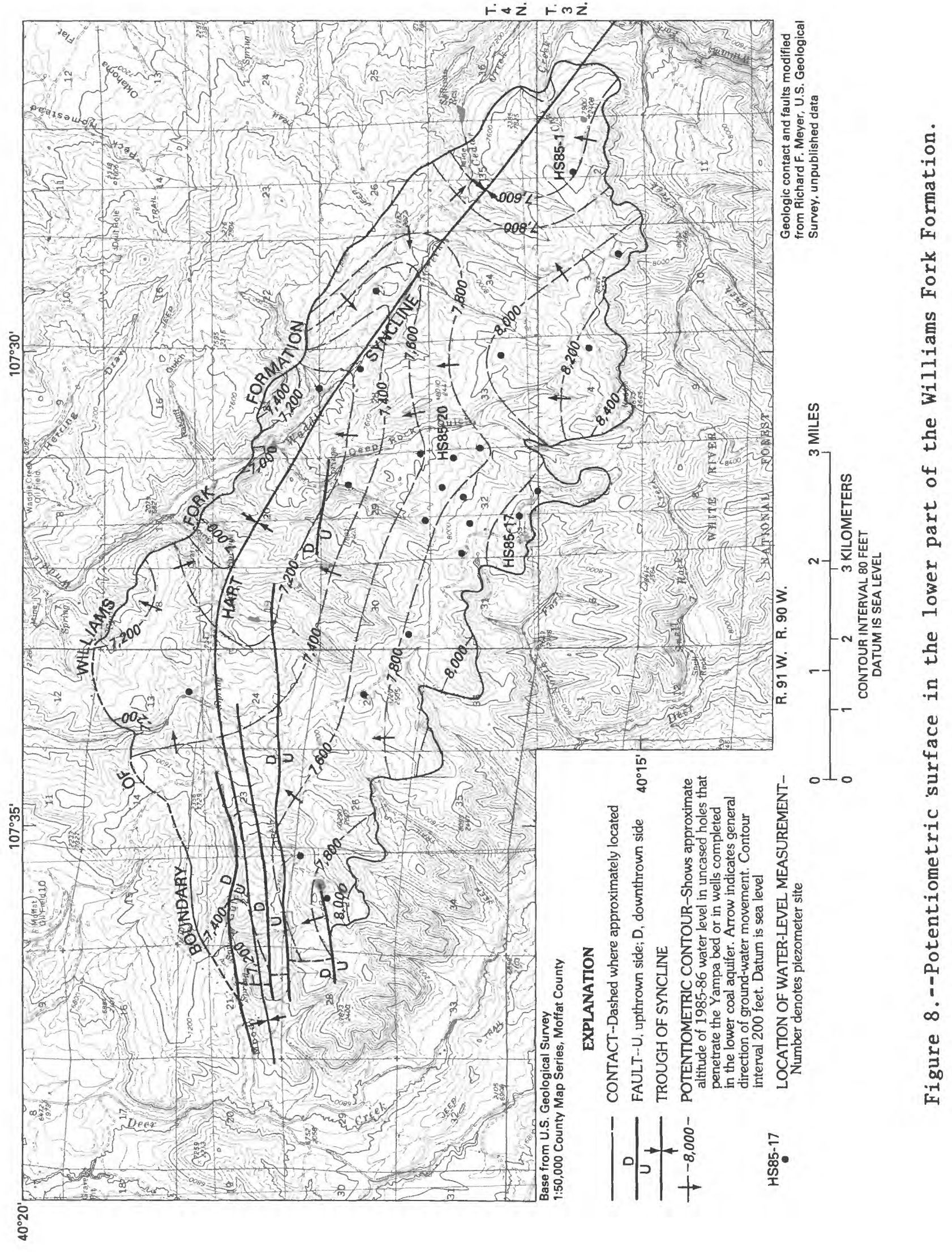




\section{Discharge from Bedrock Aquifers}

Water from the bedrock aquifers probably discharges mostly to valleys in the northern, eastern, and western parts of the study area, as indicated by the water-level contours in figure 8 . Subcrops of the bedrock-aquifer units beneath valley-fill material may discharge water to seeps and springs or directly into valley-fill aquifers. Faults and fractures in the bedrock materials also may form important conduits for discharge by enabling water movement through the fractures and across confining units.

The lower parts of the valleys of Moody Gulch, Badger Creek, Hart Gulch, Deep Rock Gulch, Waddle Creek, and Cedar Creek (p1. 1) near the margins of the basin are potential discharge areas. The upper part of the valley of Deep Rock Gulch also is a discharge area.

The rate of discharge from the aquifers can be estimated by ground-water flow calculations using hydraulic gradients indicated in figure 8 and aquifer configuration and transmissivity data. If the hydraulic gradients indicated in figure 8 are generally representative of the potentiometric surfaces in the upper coal, lower coal, and Trout Creek aquifers, then the discharge from these three aquifers likely totals about $1 \mathrm{ft}^{3} / \mathrm{s}$.

Gain-and-loss investigations were done during a period of base flow in Deep Rock Gulch and in Waddle Creek in 1986 to identify stream reaches that may be gaining flow from bedrock aquifer discharge or losing flow to bedrock aquifer recharge. A summary of the information collected during the gainand-loss investigations is listed in table 1; the locations of the dischargemeasurement sites are shown on plate 1. All measurements have an accuracy of about 5 percent and were made using a 3-in. flume or current-meter measurement techniques.

On October 16, 1986, discharge from the bedrock formations caused a $0.68-\mathrm{ft}^{3} / \mathrm{s}$ increase in streamflow in the $2.51-\mathrm{mi}$ reach of Deep Rock Gulch between the beginning of flow and site DR14. Cumulative discharge gains along Deep Rock Gulch were calculated by subtracting out tributary discharges, which allowed the main-stem increases in discharge to be evaluated. A graph of these cumulative main-stem discharge gains versus distance along Deep Rock Gulch (fig. 9) shows that Deep Rock Gulch is a gaining stream along most of its length. Progressing down Deep Rock Gulch, one goes up-section stratigraphically, from below the Trout Creek Sandstone in the Iles Formation near the headwaters of Deep Rock Gulch to the upper part of the Williams Fork Formation near the mouth of Deep Rock Gulch. From measurement sites DR1 to DR4 (fig. 9), the cumulative discharge gain of $0.05 \mathrm{ft}^{3} / \mathrm{s}$ probably comes from the areally continuous aquifers (upper coal, lower coal, and Trout Creek aquifers), based on the geology and topography in the valley, on observed seeps with algal growth (typical of coal aquifers), and on water-level contours (fig. 8). Between sites DR4 and DR9, the discharge gains probably come from local sandstone units in the upper part of the Williams Fork Formation. The largest gain in flow occurred in the reach between sites DR9 and DR14. This reach crosses a mapped fault, the axis of the Hart Syncline (where fracturing may be more prevalent), and outcrops of the Twentymile Sandstone and underlying local sandstone units, all of which may discharge water to streamflow. 
Table 1.--Sumary of gain-and-loss investigations in Deep Rock Gulch and Waddle Creek

[ft $\mathrm{ft}^{3} / \mathrm{s}$, cubic feet per second; --, not applicable; + , gain; -, loss]

\begin{tabular}{|c|c|c|c|c|c|c|}
\hline $\begin{array}{l}\text { Site } \\
\text { name }\end{array}$ & $\begin{array}{c}\text { Date of } \\
\text { discharge } \\
\text { measurement }\end{array}$ & $\begin{array}{c}\text { Distance along } \\
\text { Waddle Creek } \\
\text { (miles above } \\
\text { mouth) }\end{array}$ & $\begin{array}{l}\text { Main-stem } \\
\text { discharge } \\
\left(\mathrm{ft}^{3} / \mathrm{s}\right)\end{array}$ & $\begin{array}{l}\text { Tributary } \\
\text { discharge } \\
\left(\mathrm{ft}^{3} / \mathrm{s}\right)\end{array}$ & $\begin{array}{l}\text { Incremental } \\
\text { main-stem } \\
\text { discharge gain } \\
\text { or loss } \\
\left(\mathrm{ft}^{3} / \mathrm{s}\right)\end{array}$ & $\begin{array}{l}\text { Cumulative } \\
\text { main-stem } \\
\text { discharge } \\
\text { change } \\
\left(\mathrm{ft}^{3} / \mathrm{s}\right)\end{array}$ \\
\hline \multicolumn{7}{|c|}{ DEEP ROCK GULCH } \\
\hline DR6 & $08-28-86$ & 1.51 & 0.05 & -- & +0.05 & 0.05 \\
\hline DR9 & $08-28-86$ & .71 & .22 & -- & +.17 & .22 \\
\hline DR10 & $08-28-86$ & - & -- & 0.08 & - & $\cdots$ \\
\hline DR11 & $08-28-86$ & .65 & .48 & - & +.18 & .40 \\
\hline DR12 & $08-28-86$ & .45 & .40 & $\cdots$ & -.08 & .32 \\
\hline \multicolumn{7}{|l|}{$\begin{array}{l}\text { station } \\
\text { 09249455) }\end{array}$} \\
\hline DR14 & $08-28-86$ & .13 & .60 & -- & +.09 & .52 \\
\hline Beginning of flow & $10-16-86$ & 2.64 & -- & -- & 0 & 0 \\
\hline DR1 & $10-16-86$ & 2.49 & .05 & -- & +.05 & .05 \\
\hline DR2 & $10-16-86$ & 2.24 & .08 & -- & +.03 & .08 \\
\hline DR3 & $10-16-86$ & -- & - & .03 & - & -- \\
\hline DR4 & $10-16-86$ & 1.90 & .13 & & +.02 & .10 \\
\hline DR5 & $10-16-86$ & - & -- & .02 & -- & -- \\
\hline DR6 & $10-16-86$ & 1.51 & .18 & -- & +.03 & .13 \\
\hline DR7 & $10-16-86$ & 1.29 & .25 & -- & +.07 & .20 \\
\hline DR8 & $10-16-86$ & 1.05 & .28 & -- & +.03 & .23 \\
\hline DR9 & $10-16-86$ & .71 & .30 & -- & +.02 & .25 \\
\hline DR10 & $10-16-86$ & -- & -- & .06 & -- & -- \\
\hline DR11 & $10-16-86$ & .65 & .39 & -- & +.03 & .28 \\
\hline DR12 & $10-16-86$ & .45 & .46 & -- & +.07 & .35 \\
\hline \multicolumn{7}{|l|}{$\begin{array}{l}\text { station } \\
\text { 09249455) }\end{array}$} \\
\hline DR14 & $10-16-86$ & .13 & .68 & -- & +.16 & .57 \\
\hline $\begin{array}{l}\text { W8 (gaging } \\
\text { station } \\
\text { 09249450) }\end{array}$ & $08-27-86$ & 6.74 & .75 & -- & +.21 & +.19 \\
\hline w9 & $08-27-86$ & 6.67 & 2.58 & $\cdots$ & $2-.17$ & $2+.02$ \\
\hline W10 & $08-27-86$ & 6.46 & .78 & - & +.20 & +.22 \\
\hline W11 (DR14) & $08-27-86$ & -- & -- & .64 & - & -- \\
\hline W12 & $08-27-86$ & 6.19 & 1.3 & - & -.12 & +.10 \\
\hline W13 & $08-27-86$ & 5.97 & 1.1 & -- & -.20 & -.10 \\
\hline W14 & $08-27-86$ & 5.19 & 1.3 & $\cdots$ & +.20 & +.10 \\
\hline $\begin{array}{l}\text { W15 (Hart Gulch, } \\
\text { near mouth) }\end{array}$ & $08-27-86$ & -- & -- & .57 & -- & -- \\
\hline W16 & $08-27-86$ & 4.53 & 1.9 & -- & +.03 & +.13 \\
\hline
\end{tabular}

${ }^{1}$ Not calculated because some tributary inflow was not measured.

${ }^{2}$ Swampy area of diffuse flow; not one distinct channel. Probably did not measure all flow through this section of valley. 


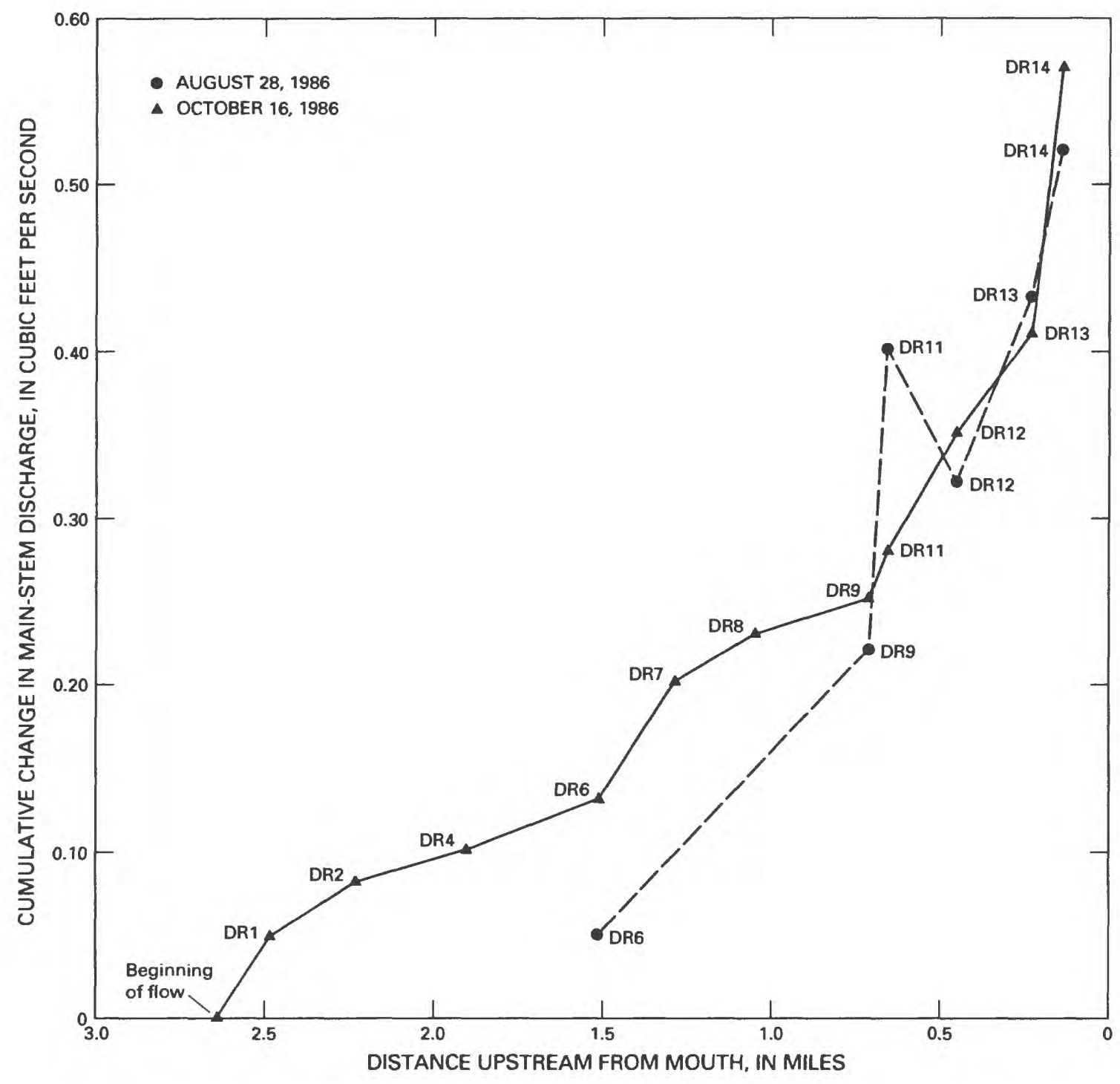

Figure 9.--Cumulative change in main-stem discharge along Deep Rock Gulch, August 28 and October 16, 1986.

Ground-water discharge to streamflow in Waddle Creek on August 27, 1986, produced a $0.75-\mathrm{ft}^{3} / \mathrm{s}$ increase in flow in the $2.1-\mathrm{mi}$ reach between sites W1 and W10 ( 1 1. 1). A graph of cumulative change in main-stem discharge versus distance along Waddle Creek between sites W3 and W16 (fig. 10) indicates that both gaining and losing reaches of Waddle Creek existed on August 27, 1986. Cumulative change in main-stem discharge at site W3 was set equal to zero in figure 10 because tributary discharge upstream from site W3 was not measured. Upstream from measurement site W5 (fig. 11A), Waddle Creek coincides with the trough of the Hart Syncline and flows across rocks of the upper part of the Williams Fork Formation. Little change in streamflow occurred in this reach (fig. 10) on August 27, 1986. 


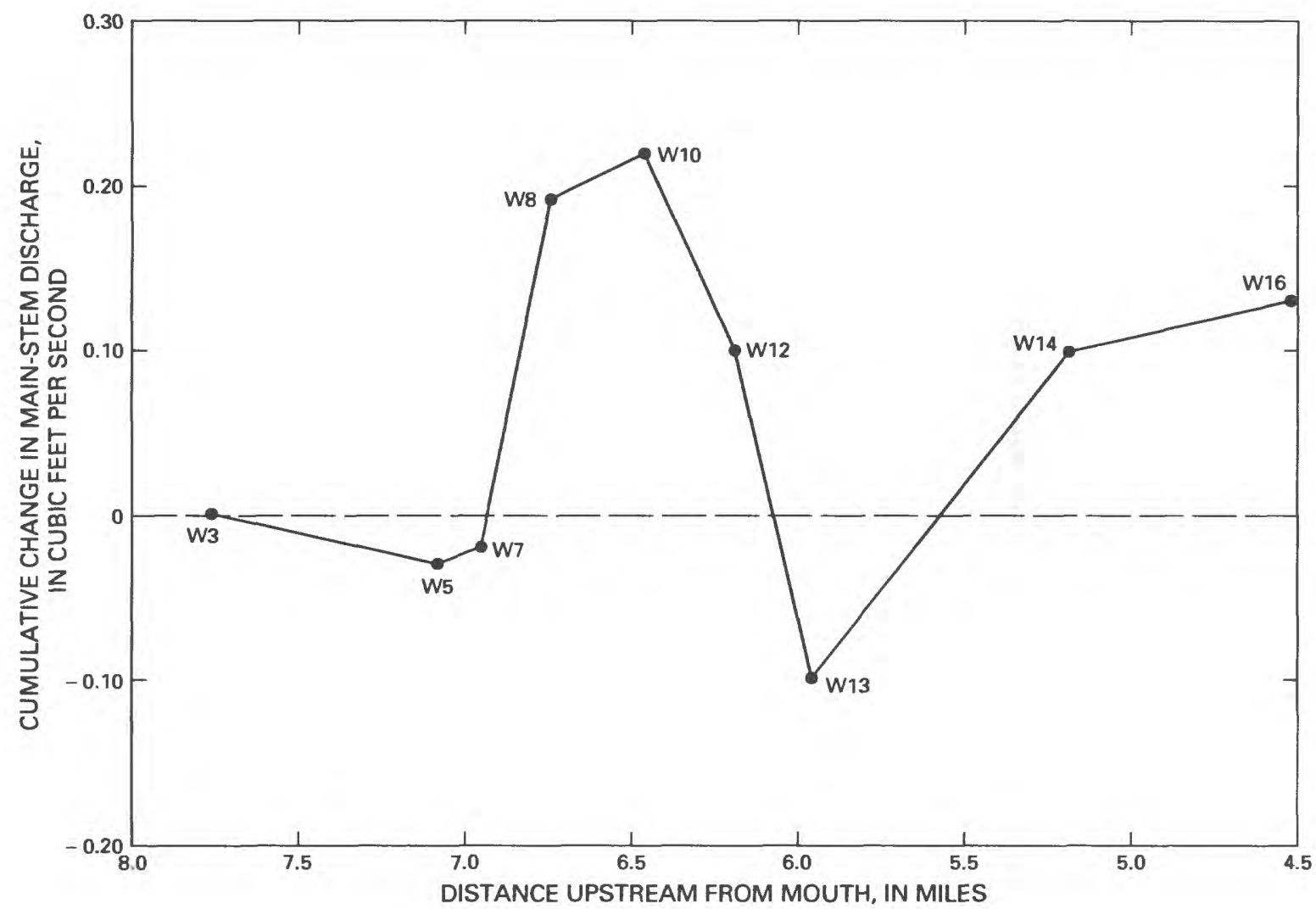

Figure 10.--Cumulative change in main-stem discharge along Waddle Creek, August 27, 1986.

From measurement sites W5 to W13, Waddle Creek flows in a more northerly direction than the trend of the Hart Syncline and goes down-section stratigraphically, traversing outcrops of the Williams Fork Formation and the upper part of the Iles Formation, including the Trout Creek Sandstone (fig. 11B). From measurement sites $W 7$ to $W 8$, the incremental gain in Waddle Creek discharge of $0.21 \mathrm{ft}^{3} / \mathrm{s}$ (table 1) probably came from the local sandstone units in the upper part of the Williams Fork Formation or from the upper part of the areally continuous bedrock aquifers or both. The flow path through these units is shown schematically in figure 7. From sites w8 to W10 there probably was little change in streamflow; the discharge measurement at site W9 (table 1 ) is of questionable validity because it was made in a swampy area and all the streamflow probably was not measured. Downstream from site W10, a pond and a wider valley make interpretation of discharge measurements difficult. Between measurement sites W10 and W12, Waddle Creek crosses the Yampa bed. This occurs at the site of a pond on Waddle Creek, which obscures discharge gains and losses in this reach. Site W12 is located downstream from where Waddle Creek crosses the Yampa bed but upstream from the Williams Fork Formation and Iles Formation contact; site W13 is located downstream from the contact. As indicated in figure 10 , there was a $0.2-\mathrm{ft}^{3} / \mathrm{s}$ loss of streamflow 


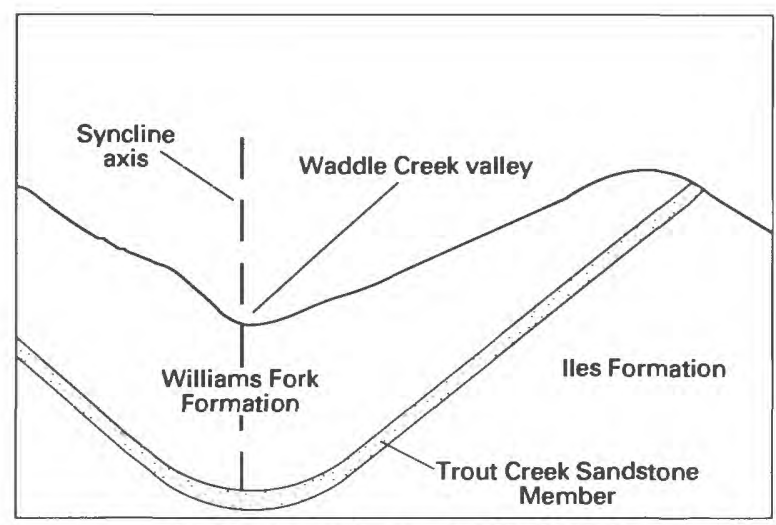

A. Upstream from site W5, Waddle Creek valley is in upper part of Williams Fork Formation

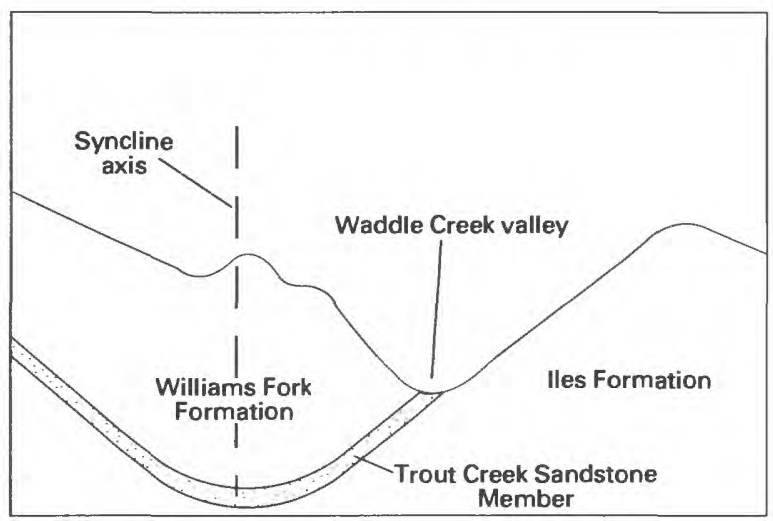

B. Between sites W5 and W13, Waddle Creek valley is in lower part of Williams Fork Formation

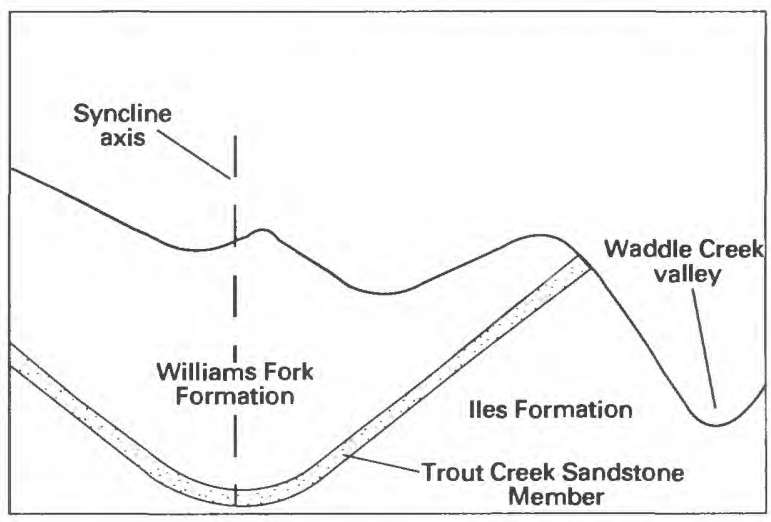

C. Downstream from site W13, Waddle Creek valley is in lles Formation

Figure 11.--Generalized sections showing relation of Waddle Creek valley to geologic structure. 
across the Williams Fork Formation and Iles Formation contact (sites W12 to W13), which is at the top of the Trout Creek Sandstone Member. Although indicated by only one set of measurements on August 27, 1986, this loss may result from additional underflow in the valley in this reach or local recharge to the Trout Creek Sandstone.

Downstream from measurement site W13, Waddle Creek flows over the part of the Iles Formation that is stratigraphically lower than the Trout Creek Sandstone Member (fig. 11C). Downstream from measurement site W16, Waddle Creek flows over the Mancos Shale. The $1.44 \mathrm{mi}$ reach of Waddle Creek between sites $W 13$ and $W 16$ gained $0.23 \mathrm{ft}^{3} / \mathrm{s}$ of streamflow (fig. 10).

Ground water in the sandstone units in the upper part of the Williams Fork Formation discharges to springs and seeps in valley bottoms and on valley sides where the units have been truncated and exposed by deeply incised stream valleys, such as in lower reaches of Deep Rock Gulch and in the upper reaches of Hart Gulch, Moody Gulch, and Badger Creek. An inventory and sampling of the major springs in the area was done as part of this study (table 7 in the "Supplemental Information" section at the back of this report). The locations of these springs are shown on plate 1 .

About $1.4 \mathrm{ft}^{3} / \mathrm{s}$ of streamflow in Deep Rock Gulch and Waddle Creek can be attributed to discharge from the upper and lower coal aquifers and the Trout Creek aquifer. This value is comparable to the $1-\mathrm{ft}^{3} / \mathrm{s}$ estimate of groundwater discharge based on aquifer characteristics and hydraulic gradients. The total water budget for these aquifers likely is about 1 to $2 \mathrm{ft}^{3} / \mathrm{s}$ because little ground water discharges to streamflow in other area streams.

\section{Hydraulic Characteristics of Bedrock Aquifers}

The following discussion is based on interpretation of data from 26 bedrock-aquifer monitoring wells in 14 boreholes (many have multiple completions) at 9 sites (p1. 1), constructed in August and September 1985.

\section{Hydraulic Head}

Hydraulic head decreased with depth in the topographically high part of the southern flank of the Hart Syncline as indicated by water-level measurements in wells at sites HS85-1 (fig. 12) and HS85-17 (fig. 13). At site HS85-17, for example, hydraulic head in the upper coal aquifer, as represented by the water level in well HS85-17c1S, was higher than the head in the aquifers that underlie it. Well HS85-17c1M was completed as a fully penetrating well in the lower coal aquifer; well HS85-17-4 was completed as a partially penetrating well in the upper part of the lower coal aquifer (see fig. 29 in the "Supplemental Information" section at the back of this report). The similarity of water-level fluctuations, both in direction and magnitude, in well HS85-17-4 and well HS85-17c1M, which were $23.5 \mathrm{ft}$ apart horizontally, indicates that the wells are hydraulically connected within the aquifer. Furthermore, the fact that the hydraulic head in the partially penetrating well HS85-17-4 was slightly higher than that in the fully penetrating well HS85-17c1M confirms that hydraulic head decreases with depth within the aquifer at this site and that hydraulic head is more nearly consistent over the 


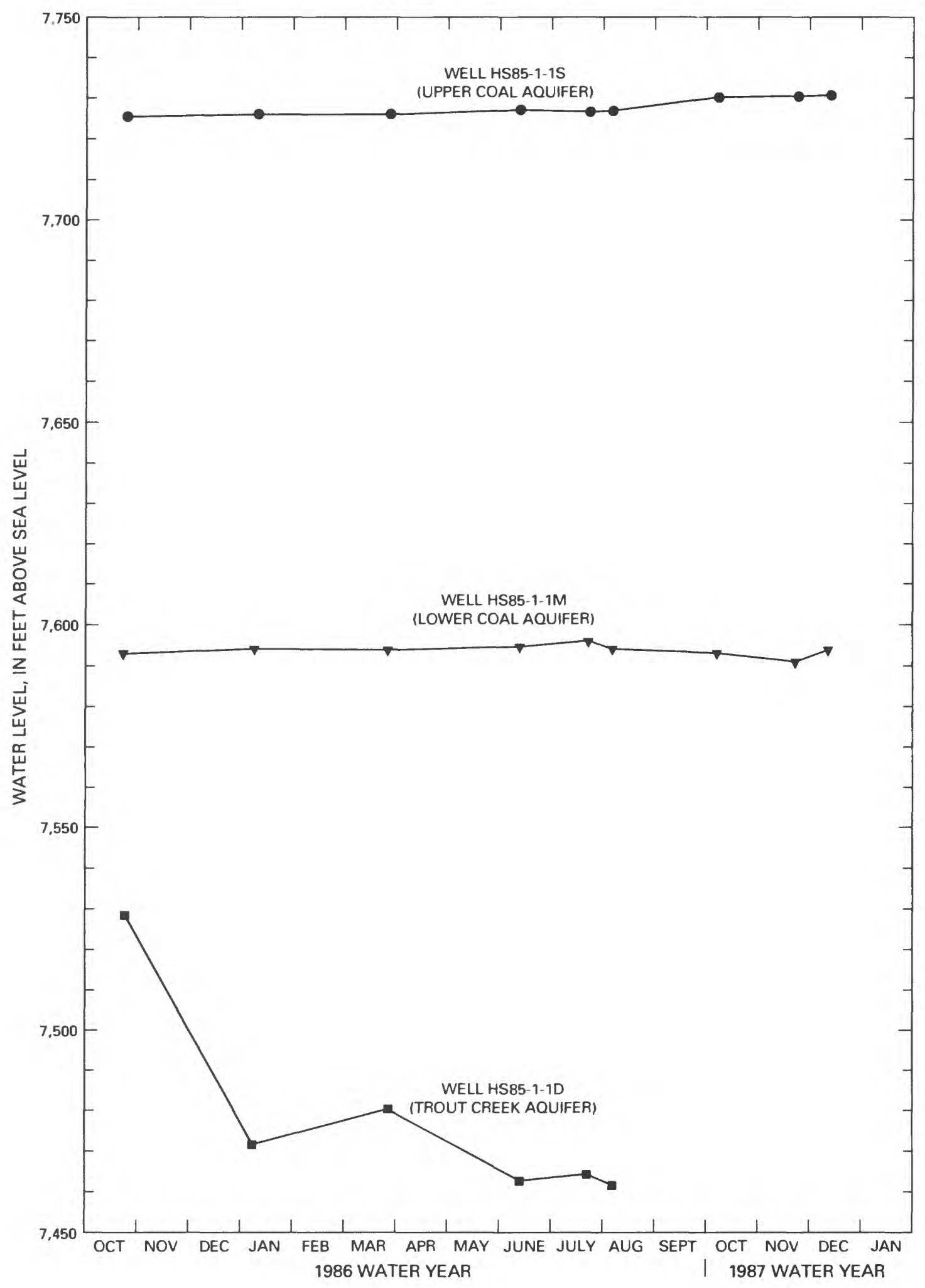

Figure 12.--Water-level hydrographs for wells completed in the upper coal aquifer, lower coal aquifer, and Trout Creek aquifer at site HS85-1. 


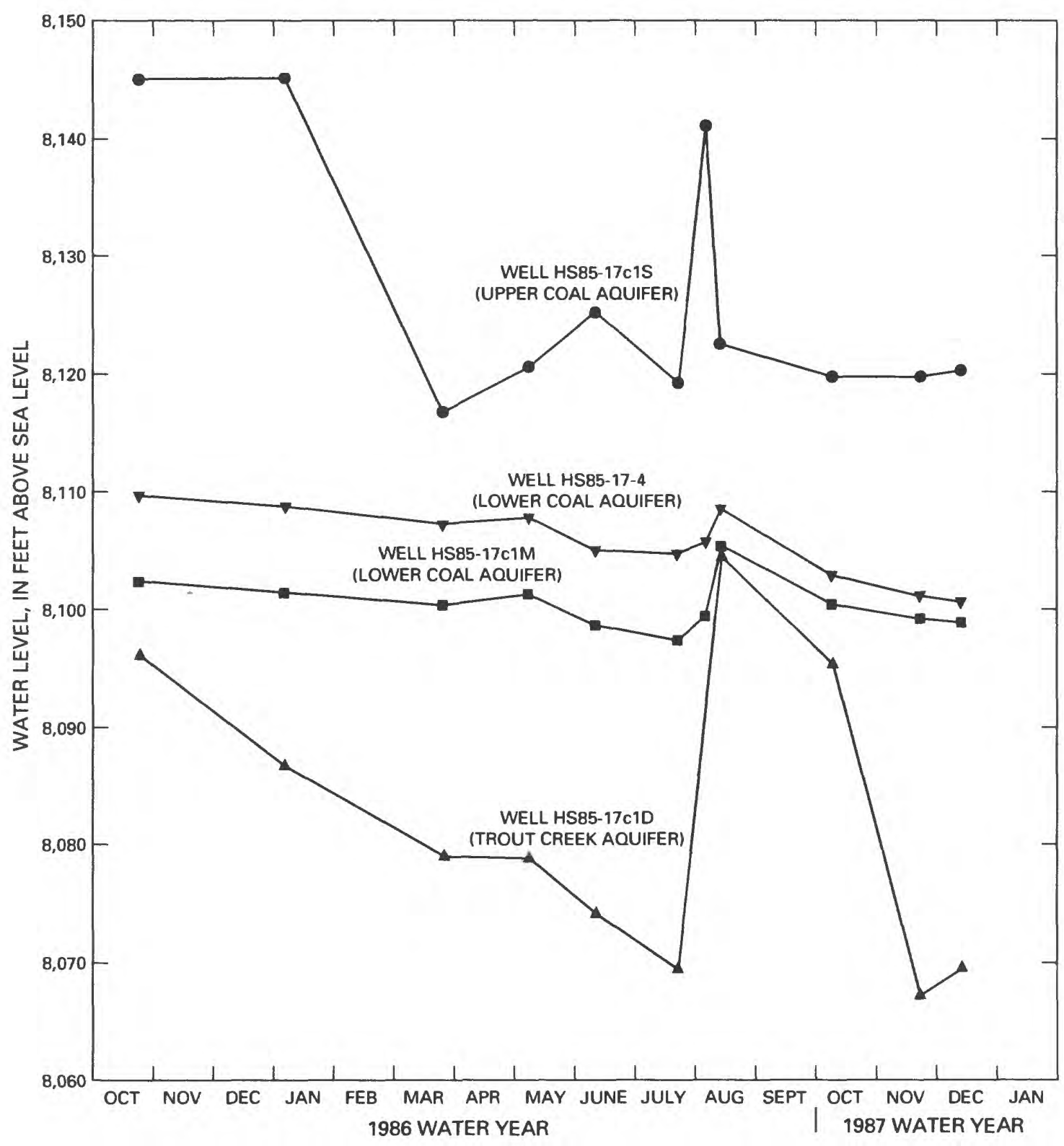

Figure 13.--Water-level hydrographs for wells completed in the upper coal aquifer, lower coal aquifer, and Trout Creek aquifer at site HS85-17. 
interval that is defined as a single aquifer than between intervals that are defined as different aquifers. Well HS85-17c1D, completed in the Trout Creek aquifer, exhibits the lowest hydraulic head of the wells in the three aquifers at this site.

In most of the valley of Deep Rock Gulch, wells completed in the upper coal aquifer flow at land surface (fig. 14). It is likely that a similar area exists in the central part of the Hart Syncline near Waddle Creek, although supporting data are sparse in this area. These wells flow because: (1) The water in the aquifer is confined by overlying and underlying confining units, and (2) the land surface slopes more steeply than the potentiometric surface of the aquifer, which causes the potentiometric surface to be above land surface in topographically low areas. As shown in figure 15, the potentiometric surface of the upper coal aquifer likely intersects the land surface at a point part-way down the north-facing hill slope. In areas downslope from that point and between Deep Rock Gulch and its major tributary, tightly cased wells completed in the upper coal aquifer can be expected to flow at the land surface (fig. 14). However, east of the valley of Deep Rock Gulch and west of the valley of its major tributary, sandstone cliffs exist at a higher altitude than the potentiometric surface of the upper coal aquifer, and wells in this area probably would not flow.

In the valley of Deep Rock Gulch near the trough of the Hart Syncline and in the valley of Waddle Creek along the trough of the Hart Syncline upstream from its confluence with Deep Rock Gulch, the altitude of the potentiometric surface in the upper coal aquifer was not well defined, because no wells were completed solely in the aquifer in this area. However, two wells drilled for coal exploration in the $1970^{\prime} \mathrm{s}$ in this area by the U.S. Geological Survey had flowing artesian head. Although it is not known from which aquifer the heads were derived, the relatively large transmissivity of the upper and lower coal aquifers (table 2) would cause heads in an open hole to be most representative of heads in these aquifers. In figure 15, an approximate straight-line extension of the potentiometric surface of the upper coal aquifer down the hillslope is inferred, as shown by the dashed line, indicating that flowing artesian conditions likely exist in the vicinity of Waddle Creek. This area along Waddle Creek is delineated in figure 14 with dashed lines to indicate the approximate area of flowing artesian conditions.

Although data are not available to define areas where flowing wells may be constructed in the lower coal or the Trout Creek aquifers, some information can be postulated about head relations between the aquifers. In recharge areas, heads generally decrease with greater depth to the aquifer, as corroborated by the piezometer data from the Hart Syncline area (figs. 12 and 13). In discharge areas, heads generally increase with greater depth to the aquifer, as has been observed in nearby coal aquifers of the Yampa coal field (Robson and Stewart, 1990). The geology and hydrology of the Hart Syncline area is similar to that in the nearby areas where heads increase with depth. This similarity indicated that heads in the lower coal and Trout Creek aquifers may be higher than those in the upper coal aquifer near important areas of discharge. If higher heads exist in the deeper aquifers, the areas where flowing wells may be constructed in the deeper aquifer may be more numerous and extensive than that indicated for the upper coal aquifer (fig. 14). 


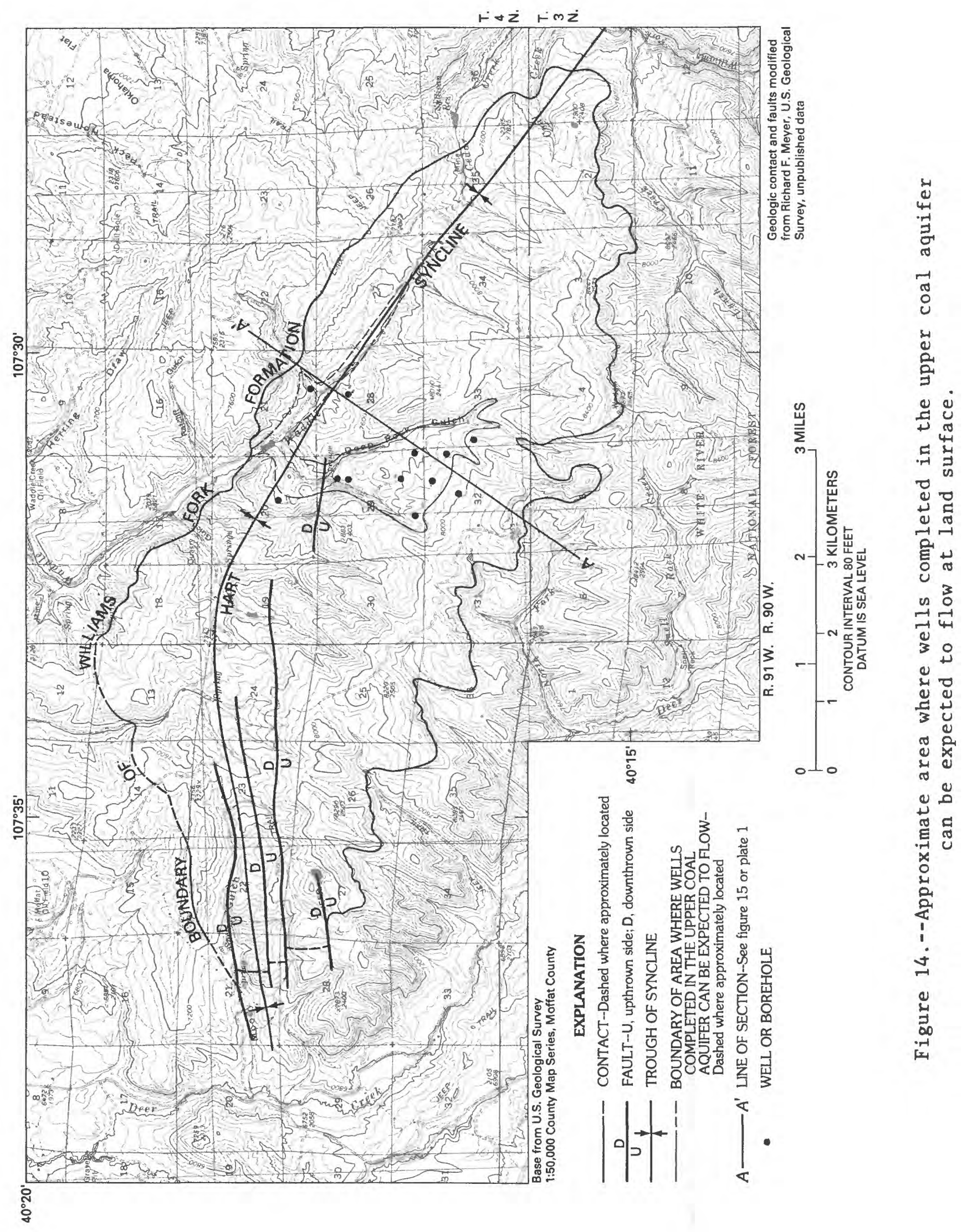




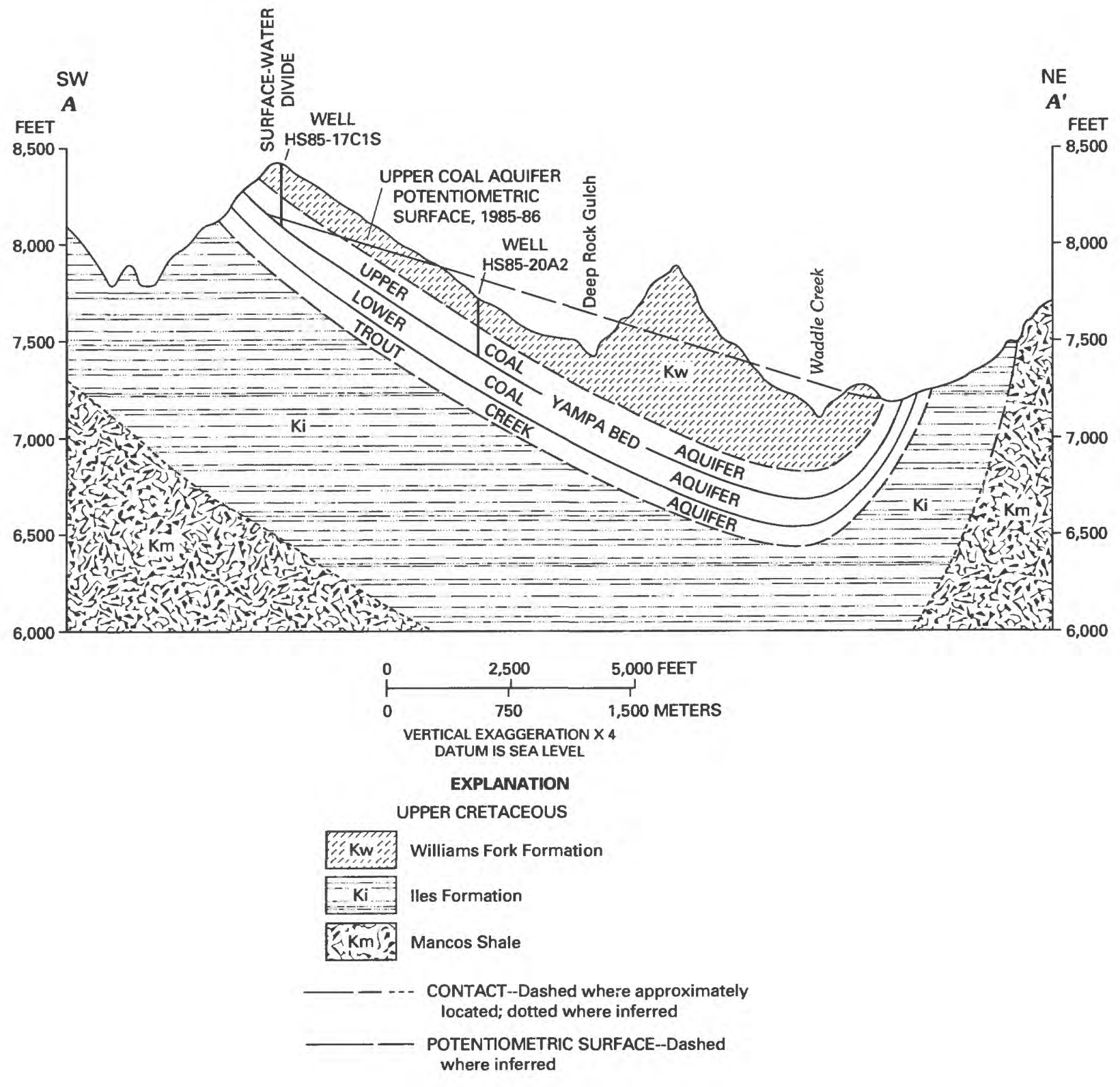

Figure 15.--Generalized hydrogeologic section showing potentiometric surface in the upper coal aquifer (trace of section shown in fig. 14 and on pl. 1). 
Table 2.--Summary of hydraulic coefficients of bedrock aquifers obtained from analyses of aquifer tests

\begin{tabular}{|c|c|c|c|c|c|c|c|c|c|}
\hline \multirow{3}{*}{$\begin{array}{l}\text { Aqui- } \\
\text { fer- } \\
\text { test } \\
\text { site }\end{array}$} & \multirow{3}{*}{$\begin{array}{c}\text { Well } \\
\text { that } \\
\text { was } \\
\text { stressed }\end{array}$} & \multirow{3}{*}{$\begin{array}{l}\text { Duration } \\
\text { and type } \\
\text { of stress }\end{array}$} & \multirow{3}{*}{$\begin{array}{l}\text { Aquifer } \\
\text { or unit } \\
\text { tested }\end{array}$} & \multirow{2}{*}{\multicolumn{2}{|c|}{$\begin{array}{l}\text { Location of } \\
\text { stressed well }\end{array}$}} & \multicolumn{2}{|c|}{ Transmissivity } & \multirow{3}{*}{$\begin{array}{l}\text { Horizontal } \\
\text { hydraulic } \\
\text { conduc- } \\
\text { tivity } \\
\text { (feet } \\
\text { per day) }\end{array}$} & \multirow{3}{*}{$\begin{array}{l}\text { Storage } \\
\text { coeffi- } \\
\text { cient }\end{array}$} \\
\hline & & & & & & \multirow{2}{*}{$\begin{array}{l}\text { (feet } \\
\text { squared } \\
\text { per day) }\end{array}$} & \multirow{2}{*}{$\begin{array}{c}\text { (gallons } \\
\text { per day } \\
\text { per foot) }\end{array}$} & & \\
\hline & & & & Latitude & Longitude & & & & \\
\hline HS $85-34$ & HS $85-34 c 4$ & $\begin{array}{l}1,000- \\
\text { minute } \\
\text { pumping }\end{array}$ & $\begin{array}{c}\text { Upper } \\
\text { Williams } \\
\text { Fork } \\
\text { Formation } \\
\text { sandstone }\end{array}$ & $40^{\circ} 17^{\prime} 48^{\prime \prime}$ & $107^{\circ} 33^{\prime} 36^{\prime \prime}$ & 4 & 30 & 0.8 & $5 \times 10^{-5}$ \\
\hline HS85-20 & HS85-20A2 & $\begin{array}{l}\text { 17-day } \\
\text { flowing }\end{array}$ & $\begin{array}{l}\text { Upper } \\
\text { Williams } \\
\text { Fork coal } \\
\text { aquifer }\end{array}$ & $40^{\circ} 16^{\prime} 30^{\prime \prime}$ & $107^{\circ} 31^{\prime} 06^{\prime \prime}$ & 9 & 60 & 1.3 & -- \\
\hline HS $85-17$ & HS85-17-4 & $\begin{array}{l}1,000- \\
\text { minute } \\
\text { pumping }\end{array}$ & $\begin{array}{l}\text { Lower } \\
\text { Williams } \\
\text { Fork coal } \\
\text { aquifer }\end{array}$ & $40^{\circ} 16^{\prime} 00^{\prime \prime}$ & $107^{\circ} 31^{\prime} 41^{\prime \prime}$ & 7 & 50 & 1.6 & -- \\
\hline HS $85-20$ & HS $85-20-2$ & $\begin{array}{l}400- \\
\text { minute } \\
\text { slug }\end{array}$ & $\begin{array}{c}\text { Trout } \\
\text { Creek } \\
\text { aquifer }\end{array}$ & $40^{\circ} 16^{\prime} 30^{\prime \prime}$ & $107^{\circ} 31^{\prime} 07^{\prime \prime}$ & .5 & 4 & 2.005 & -- \\
\hline
\end{tabular}

\footnotetext{
${ }^{1}$ Based on the assumptions that the water-transmitting saturated thickness is only the fractured coal layers (not the fine-grained sandstone), and that about one-half of the aggregate coal thickness is fractured.

${ }^{2}$ Based on an assumed aquifer saturated thickness equal to 100 feet.
}

\section{Transmissivity}

The transmissive properties of a sandstone unit in the upper part of the Williams Fork Formation are described based on a 1,000-minute, constant-rate pumping test at site HS85-34. The transmissive properties of the upper coal aquifer are described based on a 17-day flowing-we11 aquifer test at well HS85-20A2. The transmissive properties of the lower coal aquifer are described based on a 1,000-minute, constant-rate pumping test at site HS85-17. The transmissive properties of the Trout Creek aquifer are described based on a 400-minute slug test at well HS85-20-2. The results of these aquifer tests are described in the "Analyses of Aquifer Tests" subsection in the "Supplemental Information" section at the back of this report and are summarized in table 2 .

Transmissivity of the upper and lower coal aquifers is about 10 times that of the Trout Creek aquifer (table 2). Water-transmitting properties per unit of saturated thickness of the upper coal aquifer and the lower coal aquifer, as indicated by horizontal hydraulic-conductivity values, were about equal and were about 100 times that of the Trout Creek aquifer. The sandstone unit and the upper coal and lower coal aquifers are all fractured media; the Trout Creek aquifer is a relatively unfractured fine-grained sandstone in which water flows through the rock pores. 


\section{Storage}

The aquifer test conducted using well HS85-34c4 completed in the upper part of the Williams Fork Formation resulted in an estimate of storage coefficient of $5 \times 10^{-5}$ (table 2). Methods used for the other aquifer tests conducted did not allow for determination of storage coefficient. However, a value of $1 \times 10^{-4}$ is of a magnitude typically observed in confined aquifers (Lohman, 1979) and may be representative of the storage coefficient in the confined parts of the areally extensive aquifers.

An estimate of the volume of recoverable water in storage in the bedrock aquifers in the Hart Syncline area can be made if specific-yield values are assumed and if the saturated thickness and area of the aquifers are known. Lohman (1979) states that the specific yield of most aquifers ranges from about 0.1 to 0.3 and averages about 0.2 . A value of 0.2 means that an aquifer can yield a volume of water equal to 20 percent of the aquifer volume. A specific yield of 0.1 was assumed for the Trout Creek aquifer and the upper Williams Fork sandstone units because of their fine-grained composition and high degree of cementation, and a value of 0.15 was assumed for the Williams Fork coal aquifers. The aggregate saturated thicknesses of the water-bearing coal beds and the Trout Creek aquifer in the Hart Syncline area were estimated from geologic and geophysical logs from exploratory test holes in the area. The saturated thickness of the upper Williams Fork sandstone units was estimated based on the total thickness of the Williams Fork Formation in the area and qualitative observations of water produced from exploratory test holes that penetrated the Williams Fork Formation. In the Hart Syncline area, the Williams Fork Formation and the Trout Creek aquifer occur over an area of about $21 \mathrm{mi}^{2}$. Based on this information, the volume of recoverable water in storage in these bedrock aquifers is about 0.5 million acre-ft.

\section{Hydraulic Characteristics of Valley-Fill Aquifers}

Twelve monitoring wells were constructed in the valley-fill materials in September 1985; six wells are in Waddle Creek valley and six in Deep Rock Gulch valley (p1. 1). The wells are aligned across the valleys to facilitate construction of hydrogeologic sections across each valley (figs. 16 and 17). The wells are cased with 2-in. diameter polyvinylchloride (PVC) pipe with hacksaw-cut perforations. The annular space between the casing and the borehole was gravel packed opposite the perforations and sealed above the perforations with pelletized bentonite.

The lithology shown in figures 16 and 17 is based on examination of drill cuttings and is somewhat uncertain because of up-hole mixing of the cuttings and the difficulty of identifying the contact between the valley fill and bedrock. Cuttings that are brought to the surface on the solid-stem auger used to drill the wells commonly are mixed with material abraided from the borehole wall. It is sometimes difficult to determine the lithology of the material at the bit from such cuttings. Colluvial material consisting of weathered bedrock has been transported, primarily by gravity, down most hillsides and into the valleys. This colluvium is difficult to distinguish from the bedrock that has weathered in place at the contact between the valley fill and the bedrock. Although the lithology shown in figures 16 and 17 indicates unconsolidated materials, in-place weathered bedrock may have been encountered in most of the deeper wells. 

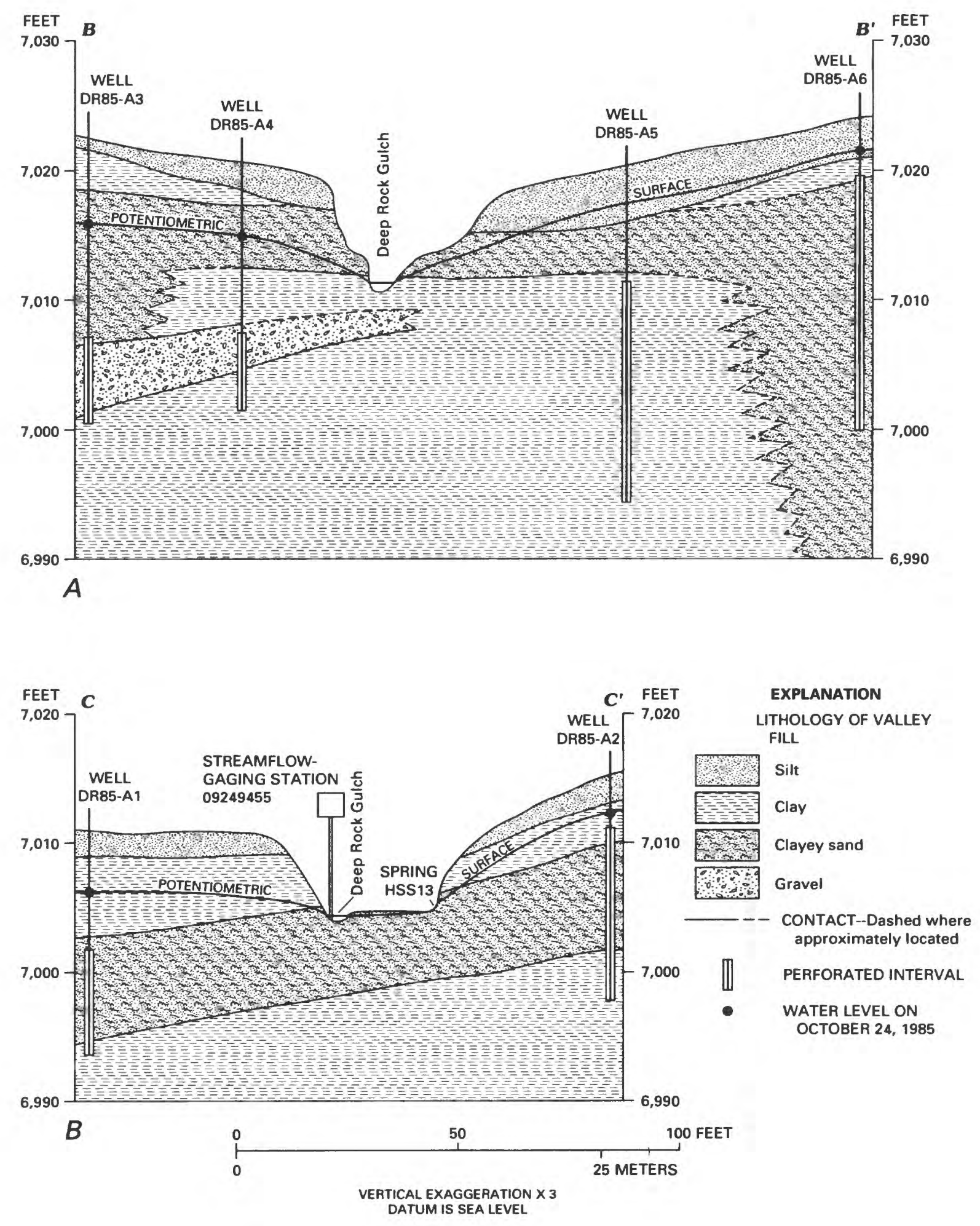

Figure 16.--Hydrogeologic sections through the valley fill in the valley of Deep Rock Gulch: (A) Section B-B', upstream from the streamflow-gaging station 09249455; and (B) Section C-C', at streamflow-gaging station 09249455, Deep Rock Gulch near Hamilton (trace of sections shown on pl. 1). 

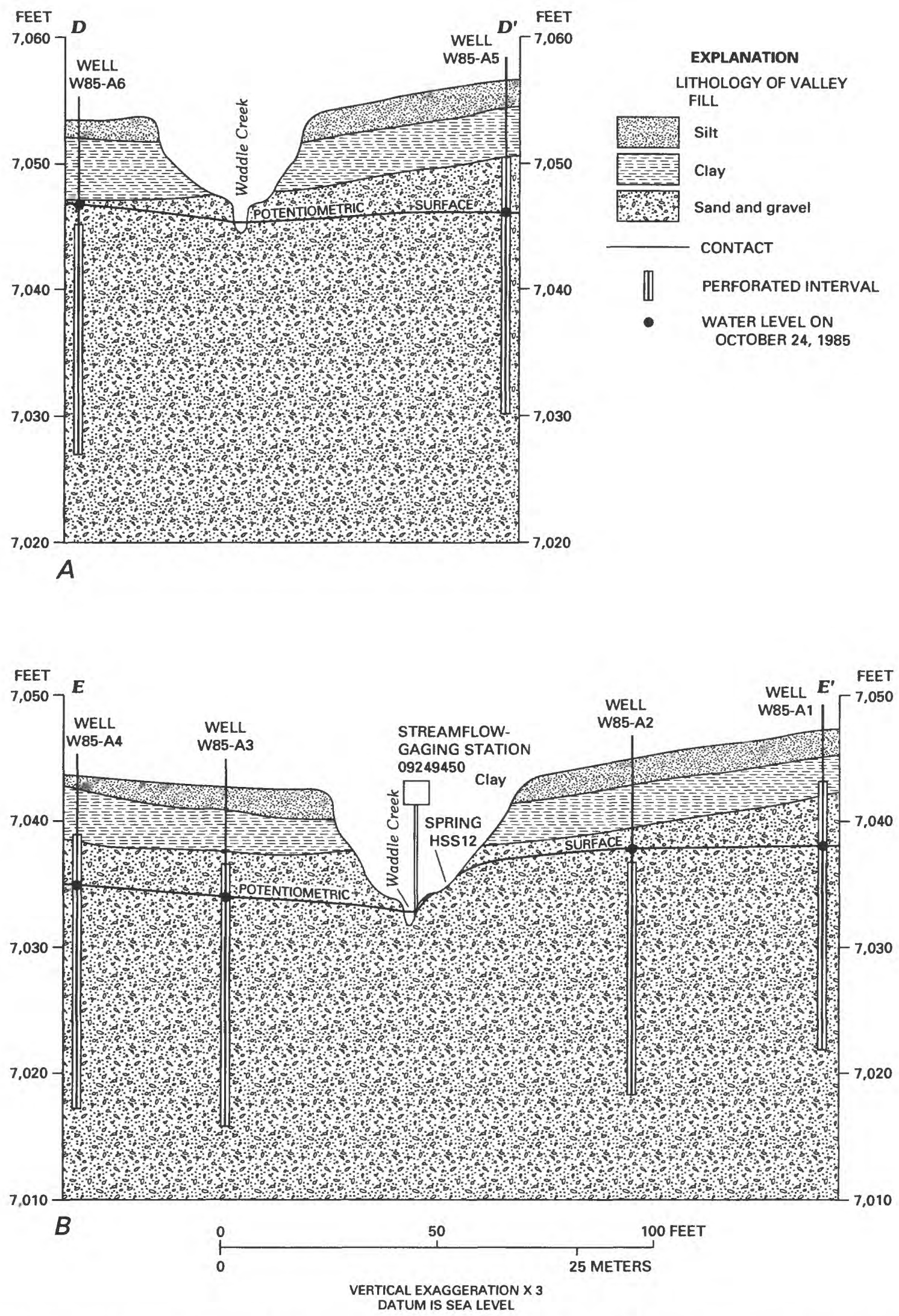

Figure 17.--Hydrogeologic sections through the valley fill in the valley of Waddle Creek: (A) Section $D-D^{\prime}$, upstream from the streamflow-gaging station 09249450; and (B) Section E-E', at streamflow-gaging station 09249450, Waddle Creek near Pagoda (trace of sections shown on pl. 1). 
Hydraulic Head

The hydrogeologic sections (figs. 16 and 17) indicate that Deep Rock Gulch and Waddle Creek were gaining streams at the locations of the sections, because the potentiometric surfaces slope toward the streams. The valley-fill aquifer at the sections in Waddle Creek is unconfined; the valley-fill aquifer at the sections in Deep Rock Gulch may be confined. Water-level hydrographs for wells in Deep Rock Gulch and Waddle Creek valleys (figs. 18 and 19) indicate that the water levels in the wells rose during January to April when snowmelt and spring rainfall provided recharge. Water levels generally declined during April to August when rainfall and runoff decreased and evapotranspiration increased.

\section{Transmissivity}

The water-transmitting properties of the valley-fill aquifers along Waddle Creek and Deep Rock Gulch were estimated based on the results of several slug tests in the monitoring wells. Although conditions were not ideal for such analysis because of an unknown percentage of partial penetration of the aquifers by the wells and because of the unknown degree of heterogeneity and anisotropy of the aquifers, order-of-magnitude estimates were made. The hydraulic conductivity of the valley-fill aquifer in the valley of Deep Rock Gulch was on the order of 0.1 to $1 \mathrm{ft} / \mathrm{d}$, and the transmissivity was on the order of 1 to $10 \mathrm{ft}^{2} / \mathrm{d}$. In the valley of Waddle Creek, the hydraulic conductivity of the valley-fill aquifer was on the order of 0.2 to $5 \mathrm{ft} / \mathrm{d}$ and the transmissivity was on the order of 5 to $100 \mathrm{ft}^{2} / \mathrm{d}$. Permeable material in the Deep Rock Gulch valley consisted of clayey sand and occasional gravel layers that were about $10 \mathrm{ft}$ in total thickness and probably were moderately permeable. In the Waddle Creek valley, permeable material consisted of sand and gravel deposits that were more than $20 \mathrm{ft}$ thick and generally were quite permeable. The transmissivity information obtained from the slug tests is consistent with this lithologic information. Specific yield of the valleyfill aquifers was not determined but is estimated to be about 0.1 . 


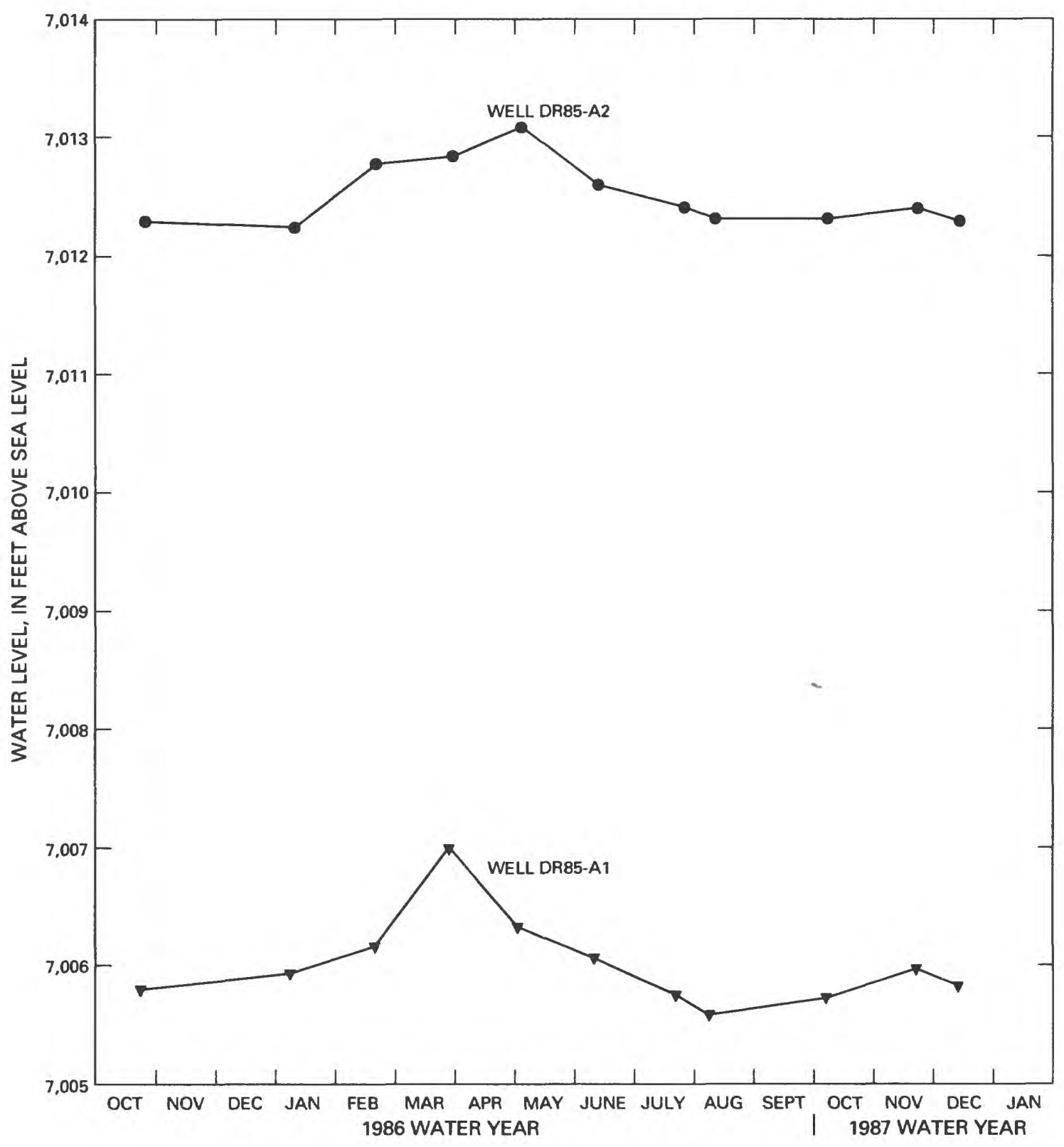

Figure 18.--Water-level hydrographs for wells completed in the valley-fill aquifer along Deep Rock Gulch. 


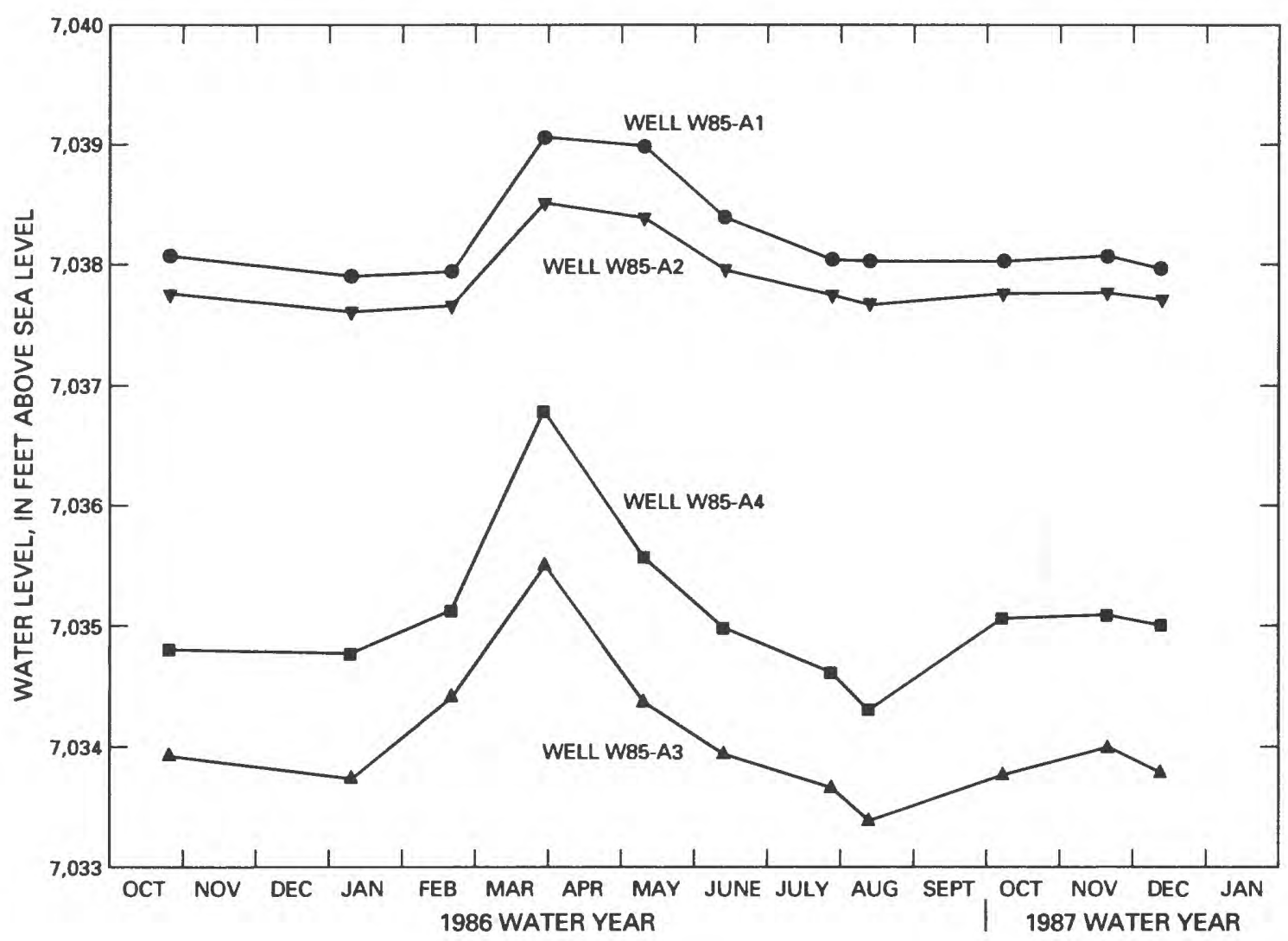

Figure 19.--Water-level hydrographs for wells completed in the valley-fill aquifer along Waddle Creek.

\section{SURFACE WATER}

\section{Streamflow}

Continuous-recording streamflow-gaging stations were maintained on Deep Rock Gulch about $0.25 \mathrm{mi}$ upstream from its mouth and on Waddle Creek about 0.35 mi upstream from its confluence with Deep Rock Gulch (p1. 1) from October 1985 through December 1986. A 15-month period of record such as this is not sufficient to assess accurately a full range of temporal variations in discharge in the area; nonetheless, discharge data for the 1986 water year were obtained and are listed in table 3 .

\section{Suspended-Sediment Discharge}

Ten suspended-sediment samples were collected at each of the streamflowgaging stations between January 8 and October 7,1986 . The suspended-sediment concentration and stream discharge were measured and used to define the relation between instantaneous suspended-sediment discharge and stream discharge 
Table 3.--Streamflow data for gaging stations in the Hart Syncline area for the 1986 water year

\begin{tabular}{|c|c|c|c|c|c|c|c|}
\hline $\begin{array}{l}\text { Station } \\
\text { name }\end{array}$ & $\begin{array}{l}\text { Station } \\
\text { number }\end{array}$ & $\begin{array}{l}\text { Drain- } \\
\text { age } \\
\text { area } \\
\text { (square } \\
\text { miles) }\end{array}$ & $\begin{array}{c}\text { Mean } \\
\text { daily } \\
\text { dis- } \\
\text { charge } \\
\text { (cubic } \\
\text { feet per } \\
\text { second) }\end{array}$ & $\begin{array}{l}\text { Maximum } \\
\text { discharge } \\
\text { (cubic } \\
\text { feet per } \\
\text { second) }\end{array}$ & $\begin{array}{l}\text { Date of } \\
\text { maximum } \\
\text { discharge }\end{array}$ & $\begin{array}{c}\text { Minimum } \\
\text { daily } \\
\text { dis- } \\
\text { charge } \\
\text { (cubic } \\
\text { feet per } \\
\text { second) }\end{array}$ & $\begin{array}{c}\text { Date (s) } \\
\text { of } \\
\text { minimum } \\
\text { daily } \\
\text { dis- } \\
\text { charge }\end{array}$ \\
\hline $\begin{array}{l}\text { Deep Rock } \\
\text { Gulch } \\
\text { near } \\
\text { Hamilton }\end{array}$ & 09249455 & 3.53 & 1.72 & 18 & $04-25-86$ & 0.20 & $12-13-85$ \\
\hline $\begin{array}{l}\text { Waddle } \\
\text { Creek } \\
\text { near } \\
\text { Pagoda }\end{array}$ & 09249450 & 5.24 & 1.57 & 11 & $04-25-86$ & .30 & $\begin{array}{c}12-12-85 \\
\text { to } \\
12-14-85\end{array}$ \\
\hline
\end{tabular}

for Deep Rock Gulch (fig. 20) and Waddle Creek (fig. 21). Daily suspendedsediment discharges then were computed using the daily mean stream discharges for each creek (U.S. Geological Survey, 1986a) and the regression equations shown in figures 20 and 21 . These daily suspended-sediment discharges then were summed to obtain an estimated annual suspended-sediment discharge for each creek for the period of record. At the streamflow-gaging station on Deep Rock Gulch, suspended-sediment discharge for October 1985 through December 1986 was about 640 tons/yr, about 86 percent of which occurred in April and May 1986. At the streamflow-gaging station on Waddle Creek, suspended-sediment discharge for October 1985 through December 1986 was about 190 tons/yr, about 77 percent of which occurred in April and May 1986.

These estimates of annual suspended-sediment discharge are based on a short period of record. Data for streams in northwestern Colorado for which the U.S. Geological Survey maintains streamflow-gaging stations can be used to provide a qualitative indication of how mean stream discharge for the 1986 water year compared with mean stream discharge over a longer period of record. Thus, a general indication of how annual suspended-sediment discharge in the 1986 water year compared with mean annual suspended-sediment discharge over a longer period of record can be inferred. The U.S. Geological Survey streamflow-gaging station on Foidel Creek near Oak Creek, 09243800 (located about $15 \mathrm{mi}$ east of the study area), which was at an altitude similar to the streamflow-gaging stations on Deep Rock Gulch and Waddle Creek and also had a similar drainage basin area, was selected for comparison. Based on 9 years of record (water years 1976-81, 1983, 1985-86), mean water discharge at Foidel Creek near Oak Creek was $1.43 \mathrm{ft}^{3} / \mathrm{s}$; mean annual water discharge for the 1986 water year was $3.69 \mathrm{ft}^{3} / \mathrm{s}$. Therefore, the 1986 water-year data for Deep Rock Gulch and Waddle Creek might represent mean annual water discharges and annual suspended-sediment discharges that are larger than the mean for the previous 10 water years. 


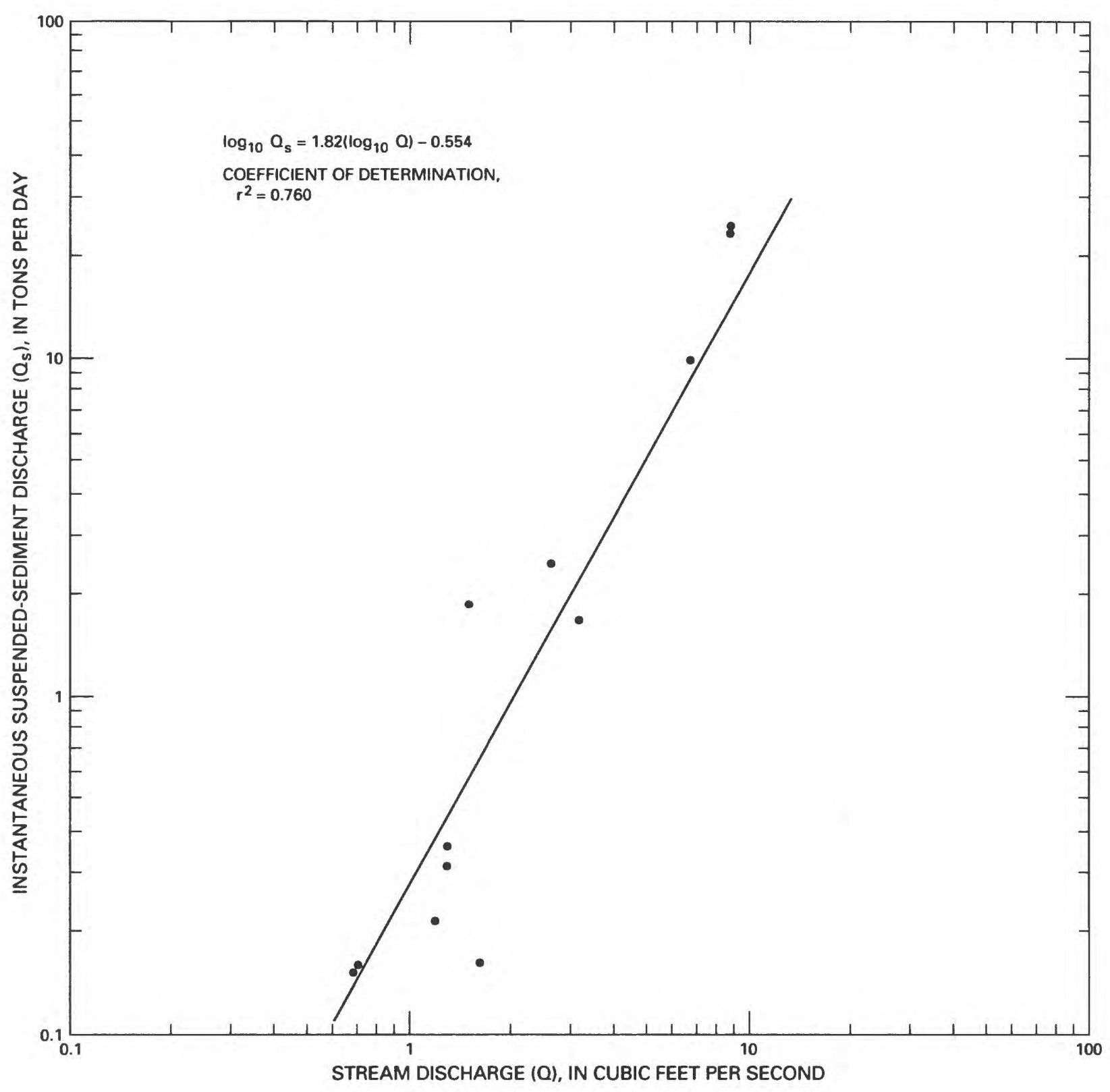

Figure 20.--Relation between instantaneous suspended-sediment discharge and stream discharge for Deep Rock Gulch near Hamilton (09249455), January 8 to October 7, 1986. 


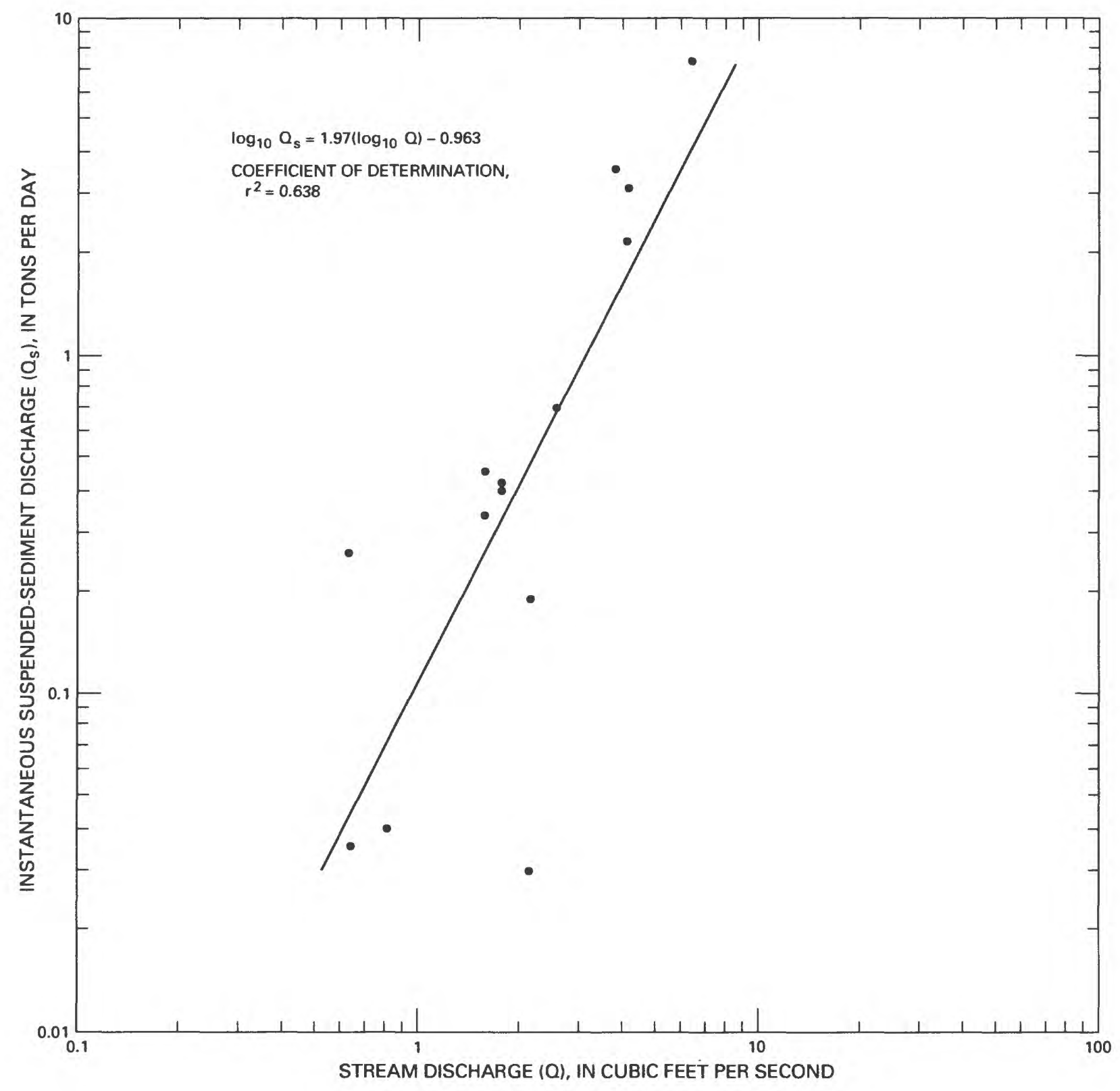

Figure 21.--Relation between instantaneous suspended-sediment discharge and stream discharge for Waddle Creek near Pagoda (09249450), January 8 to October 7, 1986. 


\section{WATER QUALITY}

Seventy-five water samples were collected from 59 sites in the Hart Syncline area for laboratory analysis of dissolved and selected total chemical constituents. Of this total, 22 samples were collected from 20 monitoring wells completed in the bedrock aquifers; 9 samples were collected from 6 monitoring wells completed in the valley-fill aquifers; 1 sample was collected from each of 18 springs; and 26 samples were collected from 15 surface-water sites. Water-quality analyses are summarized in tables 5 through 8 in the "Supplemental Information" section at the back of this report.

The suitability of water for various uses depends on the types and concentrations of dissolved chemical constituents in the water. Water-quality standards for selected constituents (Colorado Department of Health, 1979, 1981 ; U.S. Environmenta1 Protection Agency, 1988a, 1988b, 1988c) are summarized in table 4. Chemical criteria used to classify water types are listed below (modified from Piper and others, 1953, p. 26):

\begin{tabular}{|c|c|}
\hline $\begin{array}{l}\text { Cations } \\
\text { (milliequivalents per liter) }\end{array}$ & $\begin{array}{l}\text { Anions } \\
\text { (milliequivalents per liter) }\end{array}$ \\
\hline $\begin{array}{l}\text { Water type designated by single cation } \\
\text { when that cation is } 50 \text { percent or } \\
\text { more of the total cations; other- } \\
\text { wise, water type designated by } \\
\text { two cations of greatest percentage } \\
\text { concentration. }\end{array}$ & $\begin{array}{l}\text { Water type designated by single anion } \\
\text { when that anion is } 50 \text { percent or } \\
\text { more of the total anions; other- } \\
\text { wise, water type designated by } \\
\text { two anions of greatest percentage } \\
\text { concentration. }\end{array}$ \\
\hline
\end{tabular}

\section{Ground Water}

Bedrock aquifers

Major-ion composition of water samples collected from wells completed in bedrock aquifers is summarized on a trilinear diagram (fig. 22). The location of the wells and boreholes that were sampled are shown on plate 1; generalized geologic logs and completion diagrams of most of the wells and boreholes sampled are in figures 26 through 34 in the "Supplemental Information" section at the back of this report. Generalized geologic logs and completion diagrams were not available for wells HSW1 and HSW2.

Water from wells that tapped the upper coal aquifer, lower coal aquifer, or Trout Creek aquifer generally was a calcium bicarbonate type or calcium magnesium bicarbonate type near the recharge areas and a sodium bicarbonate type at locations further along the ground-water flow path. Water from wells that tapped the two water-bearing sandstone units in the upper Williams Fork Formation was a calcium bicarbonate type or a calcium sulfate type. 
Table 4.--Water-quality standards for selected characteristics and constituents (modified from Wentz and steele, 1980)

$\left[{ }^{\circ} \mathrm{C}\right.$, degrees Celsius; mg/L, milligrams per liter $\mu_{g} / \mathrm{L}$, micrograms per liter; $\leqq$, less than or equal to; --, no water-quality standards; value given is the maximum allowed, unless otherwise specified]

Water-quality characteristic or constituent
National and Colorado drinking-water regulations

(U.S. Environmental Protection Agency 1988a, 1988b, 1988c; Colorado Department of Health, 1981)

Colorado water-quality standards (Colorado Department of Health, 1979) Water supply ${ }^{1}$ Aquatic life ${ }^{2}$ Agriculture ${ }^{3}$

\section{PHYSIOCHEMICAL VARIABLES}

pH (standard units) ----.-Temperature $\left({ }^{\circ} \mathrm{C}\right)$ Dissolved oxygen (mg/L)--

\author{
$4.5 \leqq \mathrm{pH} \leqq 8.5$ \\ --
}

$55.0 \leqq \mathrm{pH} \leqq 9.0$

--
$6.5 \leqq \mathrm{pH} \leqq 9.0$

76.0

\section{$-$ \\ $-$}

MAJOR INORGANIC CONSTITUENTS (mg/L)

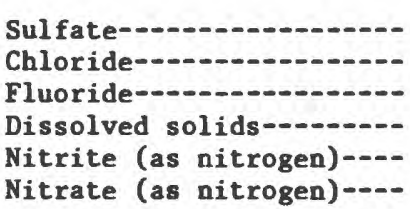

Nitrate (as nitrogen) -...

4250
4250
$8,94.0$
500
$=-$
810

250 250

-$-1.0$ 10

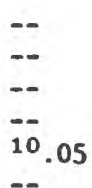

--

\section{TRACE ELEMENTS $(\mu \mathrm{g} / \mathrm{L})$}

850
81,000
300
850
450
--
810
45,000

50
$=-$
131,000
431,000
50
50
50

100

$-$

100

200

200

20

2,000

${ }^{1}$ Includes uncontaminated ground water, and ground water and surface water that requires disinfection or standard treatment (raw water).

${ }^{2}$ Includes cold-water biota (inhabitants, including trout, of waters where temperatures do not normally exceed $20^{\circ} \mathrm{C}$ ) and warm-water biota (inhabitants of waters where temperatures normally exceed $20^{\circ} \mathrm{C}$ ). Traceelement standards apply to water that has total hardness concentration that ranges from 0 to $100 \mathrm{mg} / \mathrm{L}$ as calcium carbonate; standards for water that has larger total hardness concentration may be equal or greater. Total trace-element concentrations are given, unless otherwise specified.

${ }^{3}$ Includes irrigation and stock watering.

Secondary maximum contaminant level. These "*t* control contaminants in drinking water that primarily affect the aesthetic qualities relating to the public acceptance of drinking water. *kᄎ The regulations are not Federally enforceable but are intended as guidelines for the States" (U.S. Environmental Protection Agency, 1988c).

${ }^{5}$ Applies only to ground water and surface water that requires disinfection or standard treatment (raw water).

${ }^{6}$ Applies only to cold-water biota; standard for warm-water biota is $30^{\circ} \mathrm{C}$. In addition, a maximum $3{ }^{\circ} \mathrm{C}$ increase over minimum 4-hour period lasting for 12 hours maximum from naturally occurring temperatures shall be allowed.

${ }^{7}$ Minimum allowed concentration. Applies only to cold-water biota; standard for warm-water biota is $5.0 \mathrm{mg} / \mathrm{L}$. In addition, a $7.0 \mathrm{mg} / \mathrm{L}$ standard during periods of spawning of cold-water fish may be set on a case-by-case basis.

${ }^{8}$ Primary maximum contaminant level. These " $\star \star \star$ are the maximum permissible level of a contaminant in water at the tap, are health related, and are legally enforceable" (U.S. Geological Survey, $1986 \mathrm{~b}$ ).

${ }^{9} \mathrm{~A}$ secondary maximum contaminant level of $2.0 \mathrm{mg} / \mathrm{L}$ for fluoride also has been established.

${ }^{10}$ Applies only to cold-water biota; standard for warm-water biota is $0.5 \mathrm{mg} / \mathrm{L}$.

11 Includes nitrite, as nitrogen.

12 Refers to soluble form.

${ }^{13}$ Refers to total concentration. 


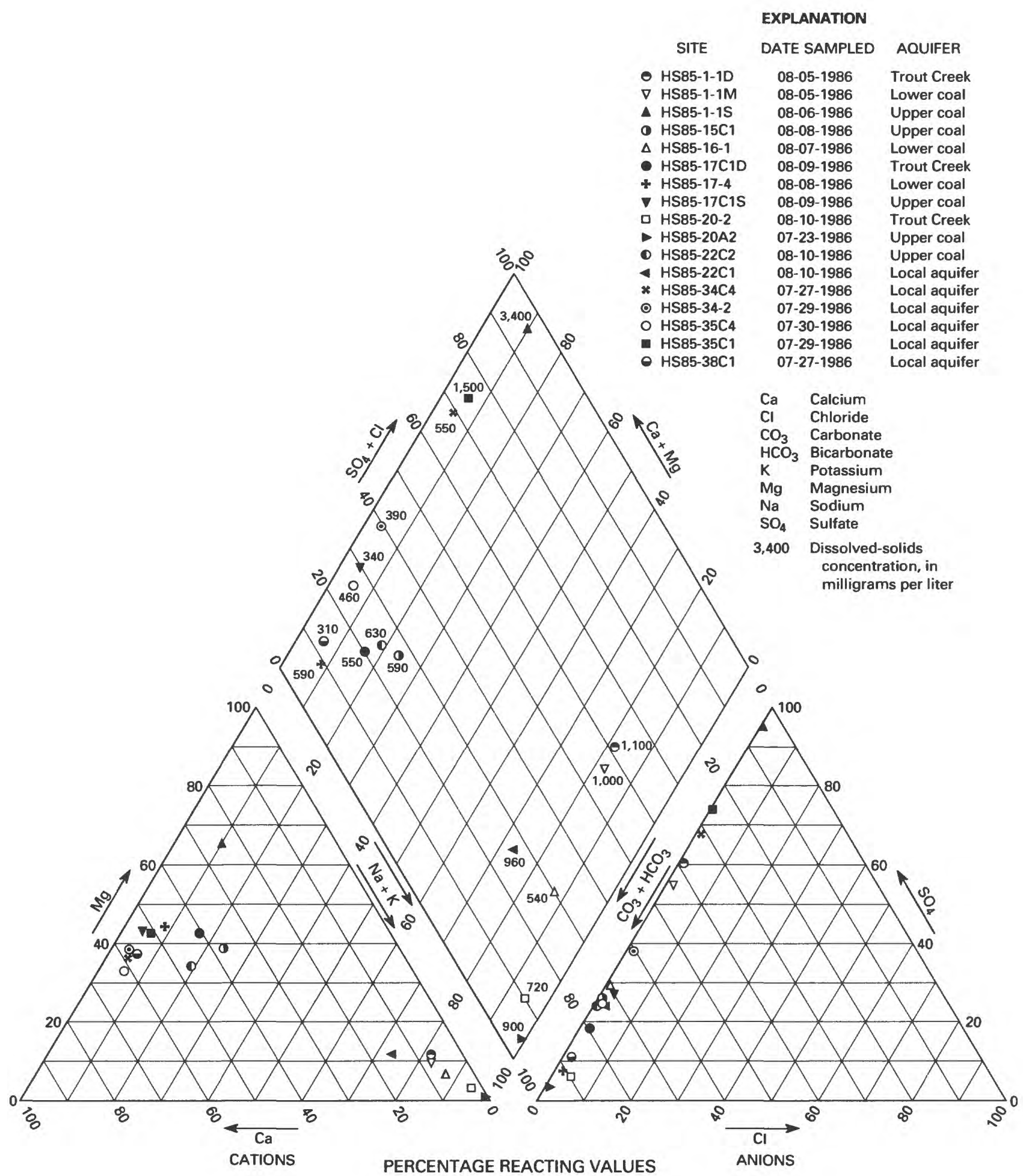

Figure 22.--Major-ion composition of water from bedrock aquifers. 
Dissolved-solids concentration in the water samples from the bedrock aquifers averaged $830 \mathrm{mg} / \mathrm{L}$. Well HS85-1-1S yielded water that had the largest dissolved-solids concentration, $3,400 \mathrm{mg} / \mathrm{L}$ (table 5); well HS85-38c1 yielded water that had the smallest dissolved-solids concentration, $310 \mathrm{mg} / \mathrm{L}$. The National drinking-water standard (secondary maximum contaminant level) for dissolved-solids concentration is $500 \mathrm{mg} / \mathrm{L}$ (table 4). Colorado and National drinking-water standards for sulfate (table 4) were exceeded in water from wells HS85-1-1D, HS85-1-1M, HS85-1-1S, and HS85-35c1 (table 5). Water from well HS85-1-1S also exceeded drinking-water standards for nitrate, selenium, and manganese. In addition, drinking-water standards for manganese were exceeded by sample waters from wells HS85-15c1, HS85-17c1D, HS85-17-4, HS85-17c1S, HS85-22c1, HS85-34c4, HS85-35c4, HS85-35c1, HSW1, and HSW2 . Drinking-water standards for iron were exceeded in water from wells HS85-34c4, HS85-35c4, and HS85-38c1. Colorado standards for zinc for aquatic life were exceeded in water from wells HS85-1-1D, HS85-1-1S, HS85-15c1, and HS85-34c4.

\section{Valley-Fill Aquifers}

The major-ion composition of water from wells completed in the valleyfill aquifers along Deep Rock Gulch and Waddle Creek is shown in figure 23. Water type from all the valley-fill monitoring wells that were sampled was calcium magnesium bicarbonate, except for well DR85-A3, which yielded water of calcium magnesium sulfate bicarbonate type and well W85-A6, which yielded water of sodium magnesium bicarbonate type. The calcium magnesium bicarbonate water is similar to the water type in the bedrock aquifers near their recharge areas. This similarity is compatible with the hypothesis that recharge to the valley fill near some of the monitoring wells is occurring from local sandstone units in the upper Williams Fork Formation. However, the large percentage of sodium in water from well W85-A6 indicates that the valley-fill aquifer in the valley of Waddle Creek also may receive some recharge from the areally continuous aquifers in the lower part of the Williams Fork Formation. Sodium is derived from clay-rich shales in the Upper Cretaceous rocks of northwestern Colorado (Clark and Williams, 1991). As water moves along a flow path it comes into contact with these shales and gradually, through cationexchange reactions, becomes sodium rich and more depleted in dissolved calcium and magnesium.

Dissolved-solids concentrations in water from sampled monitoring wells in the valley fill averaged about $730 \mathrm{mg} / \mathrm{L}$. The maximum concentration of $990 \mathrm{mg} / \mathrm{L}$ was obtained from water from well DR85-A3 (table 6); the minimum concentration of $560 \mathrm{mg} / \mathrm{L}$ was obtained from water from well W85-A4. Colorado and National drinking-water standards for sulfate (table 4) were exceeded in water from wells DR85-A3 and DR85-A6; standards for iron were exceeded in water from wells W85-A4 and DR85-A2; standards for manganese were exceeded in water from all the sampled wells; and standards for selenium were exceeded in water from well W85-A1. 


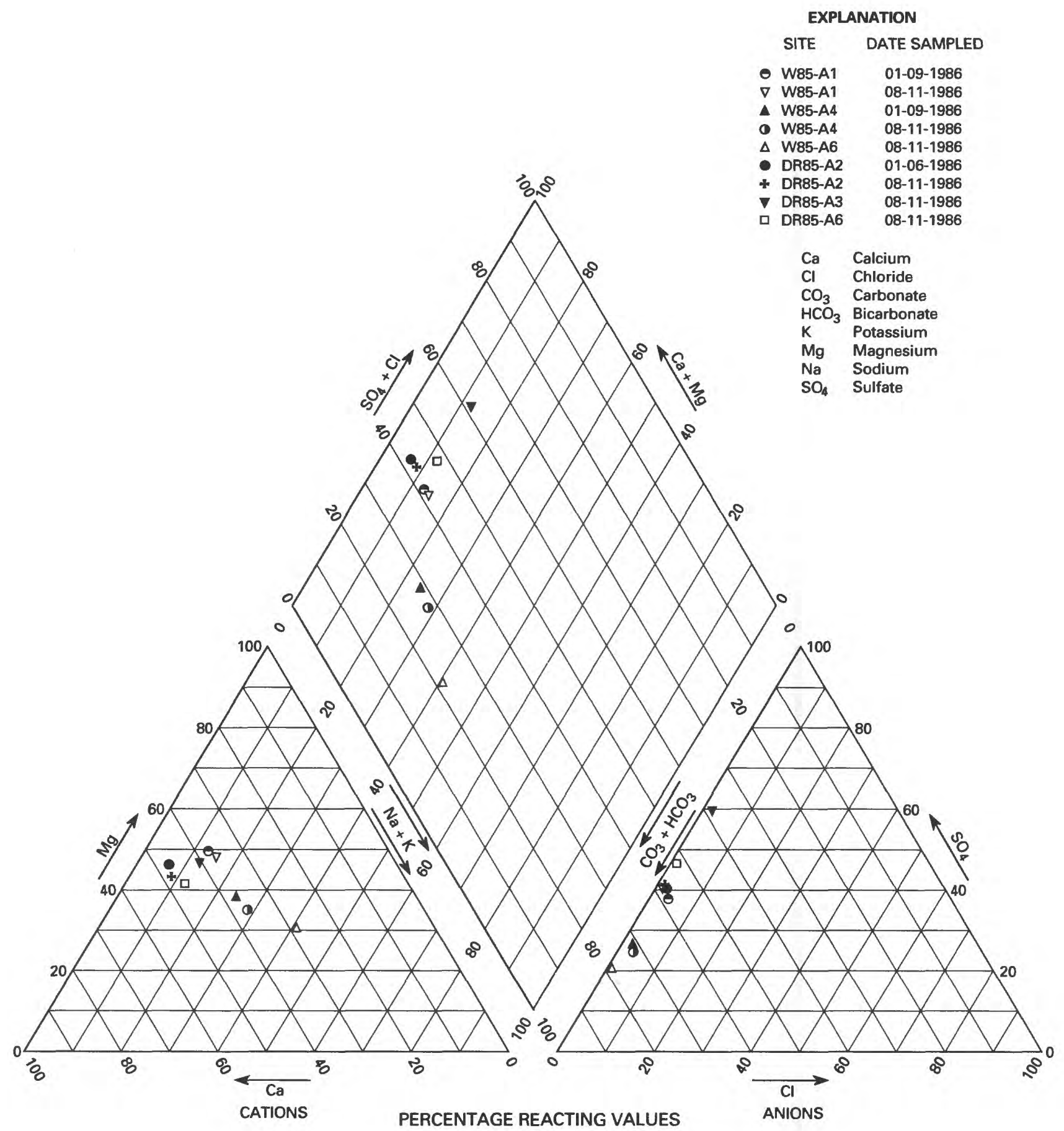

Figure 23.--Major-ion composition of water from valley-fill aquifers. 


\section{Springs}

The major-ion composition of water samples collected from springs in the Hart Syncline area (fig. 24) shows that none of the spring water had a sodiumdominant cation composition, as was common in water from the deeper parts of the areally continuous bedrock aquifers (fig. 22). Water from the springs generally was a calcium bicarbonate, calcium magnesium bicarbonate, or calcium magnesium sulfate type and was more similar in type to water in the recharge areas of the areally continuous aquifers or to water in the local sandstone aquifers. Based on these similarities in water type and the locations of the springs, it may be that most of the springs discharge water from the local sandstone aquifers.

Dissolved-solids concentrations of water samples collected from springs averaged about $1,360 \mathrm{mg} / \mathrm{L}$. The maximum value of $8,000 \mathrm{mg} / \mathrm{L}$ (table 7) was obtained from HSS14, and the minimum value of $340 \mathrm{mg} / \mathrm{L}$ was obtained from HSS6. In genera1, dissolved-solids concentrations increased as percentage of sulfate plus chloride increased. Colorado and National drinking-water standards (table 4) were exceeded for sulfate at HSS3, HSS7, HSS 14, HSS15, and HSS18; for nitrate at HSS14; for iron at HSS1, HSS3, HSS4, and HSS6; for manganese at HSS 1, HSS3, HSS4, HSS5, HSS6, HSS8, HSS9, HSS 16, HSS17, and HSS20; and for selenium at HSS14 and HSS18.

\section{Surface Water}

Surface-water samples were collected for analysis of selected dissolved and total chemical constituents at each of the two streamflow-gaging stations four times per year, at several sites along Deep Rock Gulch and along Waddle Creek in August 1986 as part of gain-and-loss investigations, and once at selected sites on other streams in the study area. The location of the sampling sites is shown on plate 1 , and the chemical analyses are summarized in table 8 in the "Supplemental Information" section at the back of this report.

The major-ion composition of the surface-water samples is shown in figure 25. Except for one sample, dominant cations were calcium or magnesium, or both, and dominant anions were bicarbonate or sulfate, or both, which is similar to water from most of the valley-fill monitoring wells and springs that were sampled. The exception was from sampling site DR10, which was the major tributary to Deep Rock Gulch. Most of the flow from the tributary originated less than $0.25 \mathrm{mi}$ upstream from the sampling site, emanating solely from the uncapped flowing well HSW1. This well probably derived much of its flow from the down-gradient parts of the areally continuous bedrock aquifers; therefore, the large percentage of sodium in water from DR10 is expected (fig. 25).

Dissolved-solids concentrations of surface-water samples averaged about $580 \mathrm{mg} / \mathrm{L}$. The minimum value of $70 \mathrm{mg} / \mathrm{L}$ (table 8 ) occurred at HSP1, a pond, and the maximum value of $800 \mathrm{mg} / \mathrm{L}$ occurred at W5. Colorado and National drinking-water standards (table 4) for sulfate were exceeded at sites W2, W5, W8, W10, W15, and W17, and at the site on North Fork Deer Creek; standards for manganese were exceeded at site DR13. 


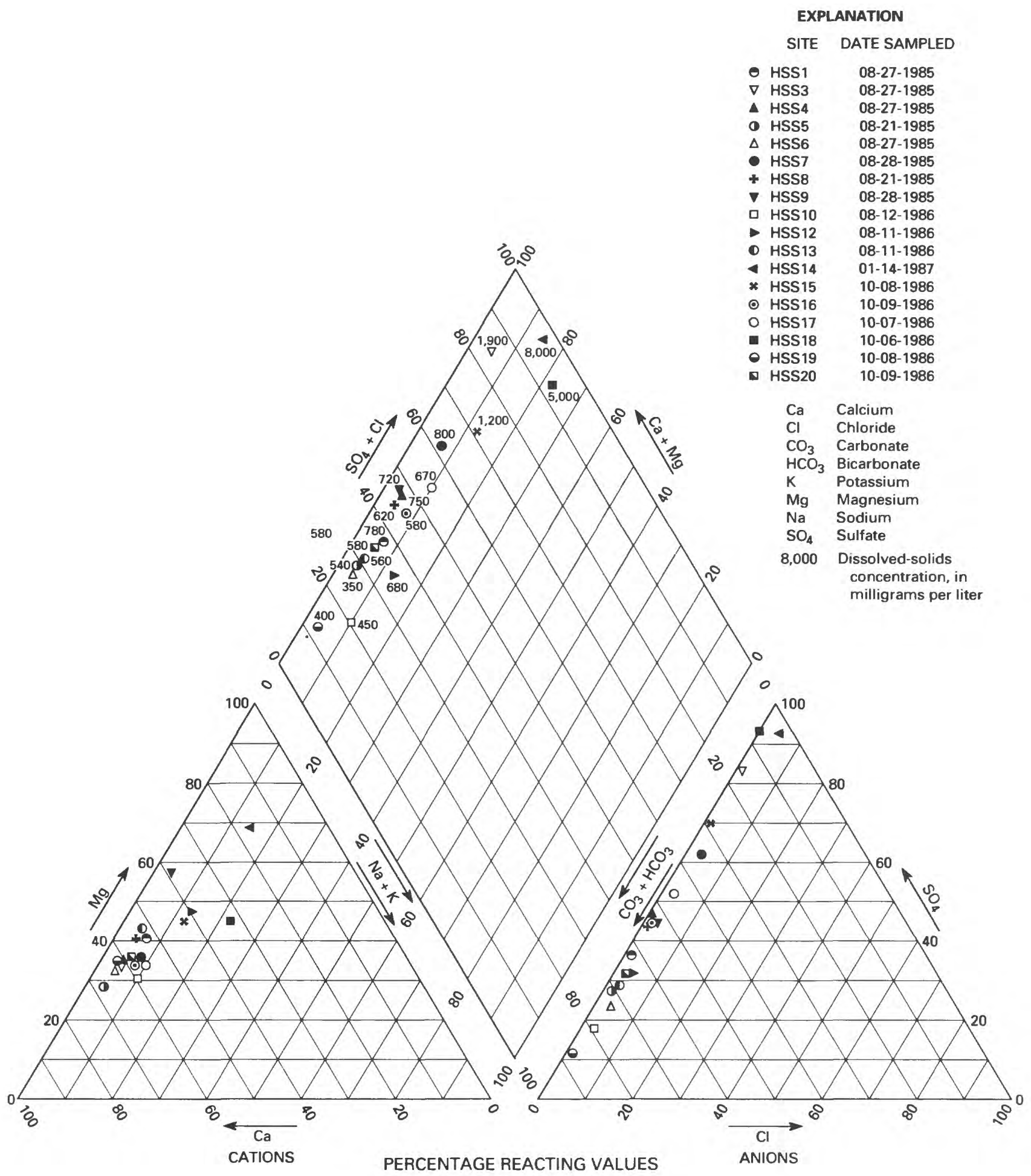

Figure 24.--Major-ion composition of water from springs. 


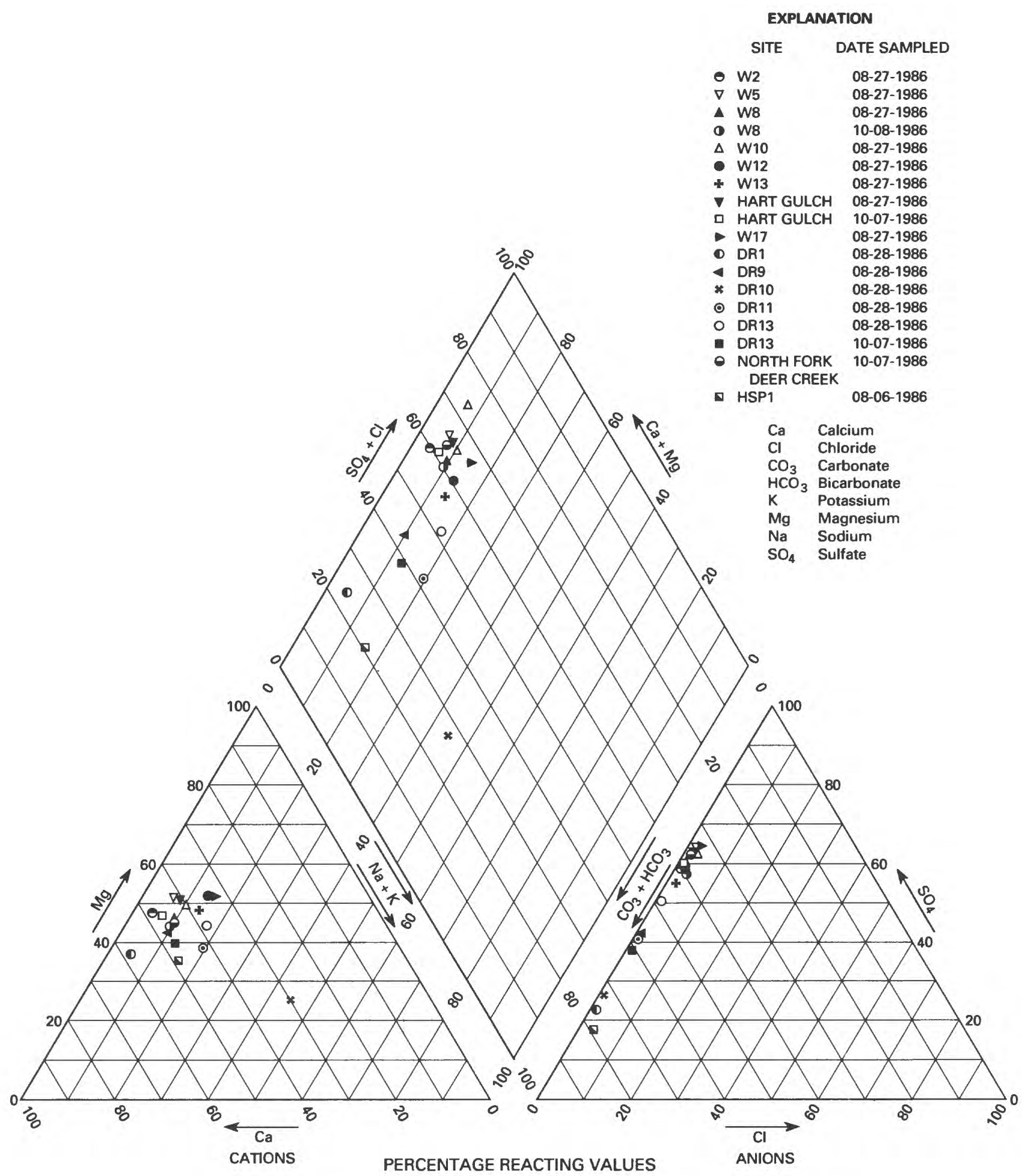

Figure 25.--Major-ion composition of surface-water samples. 
The results of this investigation are based on information from 6 weeks of well construction, followed by 15 months of hydrologic monitoring, sampling, and testing. The brief duration of this study and the small number of wells did not allow for detailed definition of the geohydrologic system. More detailed geologic mapping of the upper part of the Williams Fork Formation could help identify the depth, thickness, and extent of the shallow sandstone aquifers and the Twentymile Sandstone aquifer. Potential areas of recharge and discharge then could be better delineated. However, additional wells completed in individual aquifers, particularly in the western part of the area, could provide the most important data for future studies. Such data would enable better definition of hydraulic head and water-quality conditions in the aquifers. If sufficient additional data were available, potentiometricsurface maps could be constructed for each principal aquifer, which would allow for estimates of the rate, direction, and quantity of ground-water movement in each aquifer.

\section{SUMMARY}

The Hart Syncline area, located about $15 \mathrm{mi}$ south of the town of Craig in northwestern Colorado, is underlain by Federal coal reserves. A study to describe the hydrology of the area prior to development of the coal resources was done in cooperation with the U.S. Bureau of Land Management and Moffat County from April 1985 through September 1987. This report summarizes the results of that study. Selected coal-exploratory boreholes were converted into bedrock-aquifer monitoring wells; monitoring wells were constructed in valley-fill aquifers; and two streamflow-gaging stations were constructed in 1985 as part of a hydrologic monitoring network. Monitoring, testing, and sampling from the network continued from October 1985 through December 1986.

The Hart Syncline is the prominent structural feature of the area. The Upper Cretaceous Mancos Shale underlies the area and consists of homogeneous dark-gray marine shale; it forms the base of the bedrock-aquifer system in the area. The Upper Cretaceous Mesaverde Group, consisting of the Iles Formation and the Williams Fork Formation, overlies the Mancos Shale. The Iles Formation consists of interbedded very fine-grained to fine-grained sandstone, siltstone, shale, and coal beds. The uppermost 50 to $150 \mathrm{ft}$ of the Iles Formation is the water-bearing Trout Creek Sandstone Member, which constitutes the Trout Creek aquifer. The Williams Fork Formation overlies the Iles Formation and consists of fractured coal beds interbedded with claystone, mudstone, siltstone, and very fine-grained to fine-grained sandstone. Groundwater flow in the Williams Fork Formation is mainly in the fractured coal beds; the interbedded fine-grained rocks probably act as confining units. About 150 to $200 \mathrm{ft}$ above the base of the Williams Fork Formation is a laterally continuous, 2- to 3-ft layer of argillaceous volcanic ash, called the Yampa bed, which acts as a confining unit. The interbedded coal and finegrained rocks underlying the Yampa bed constitute the lower Williams Fork coal aquifer. Above the Yampa bed are about 150 to $250 \mathrm{ft}$ of interbedded coal and fine-grained rocks that compose the upper Williams Fork coal aquifer. Above these aquifers in the Williams Fork Formation are about $600 \mathrm{ft}$ of interbedded fine-grained rocks that contain several sandstone beds. These sandstone beds are water bearing in places, but they are not continuous throughout the Hart Syncline area. 
Recharge to the bedrock aquifers occurs locally from infiltration of precipitation on outcrops of the Trout Creek Sandstone Member and the Williams Fork Formation. Flow in bedrock aquifers is principally down dip along bedding planes from recharge areas near the margins of the syncline toward discharge areas near the larger valleys at the western, northern, and eastern margins of the Hart Syncline area. The bedrock aquifers probably discharge to springs and diffuse seeps in the valleys. In the central part of the Hart Syncline area, between Deep Rock Gulch and its major tributary, heads in the upper coal aquifer are above land surface and flowing wells are present.

Transmissivity of the bedrock aquifers was determined from four aquifer tests to range from 0.5 to $9 \mathrm{ft}^{2} / \mathrm{d}$ and the horizontal hydraulic conductivity ranged from 0.005 to $0.6 \mathrm{ft} / \mathrm{d}$. The values of hydraulic conductivity of fractured coal and fractured sandstone media are about 100 times that of the Trout Creek aquifer, in which ground-water flow occurs interstitially. The total volume of recoverable water in storage in the bedrock aquifers in the Hart Syncline area is about 0.5 million acre-ft.

Deep Rock Gulch and Waddle Creek were gaining streams at the location of several monitoring wells in the valley fill. The hydraulic conductivity of the valley-fill aquifer in the valley of Deep Rock Gulch is about 0.1 to $1 \mathrm{ft} / \mathrm{d}$, and the transmissivity is about 1 to $10 \mathrm{ft}^{2} / \mathrm{d}$. The hydraulic conductivity of the valley-fill aquifer in the valley of Waddle Creek is about 0.2 to $5 \mathrm{ft} / \mathrm{d}$, and transmissivity is on the order of 5 to $100 \mathrm{ft}^{2} / \mathrm{d}$.

The mean daily discharge of Deep Rock Gulch about 0.25 mi upstream from its mouth from October 1985 through September 1986 was $1.72 \mathrm{ft}^{3} / \mathrm{s}$. The maximum daily discharge for this period of record was $18 \mathrm{ft}^{3} / \mathrm{s}$ on April 25, 1986, and the minimum daily discharge was $0.20 \mathrm{ft}^{3} / \mathrm{s}$ on December 13, 1985. The mean daily discharge of Waddle Creek about $0.35 \mathrm{mi}$ upstream from its confluence with Deep Rock Gulch from October 1985 through September 1986 was $1.57 \mathrm{ft} / \mathrm{s}$. The maximum daily discharge for this period of record was $11 \mathrm{ft}^{3} / \mathrm{s}$ on April 25, 1986, and the minimum daily discharge was $0.30 \mathrm{ft}^{3} / \mathrm{s}$ on December 12 to 14,1985 . Deep Rock Gulch discharged about 640 tons/yr of suspended sediment at the streamflow-gaging station, 86 percent of which occurred in April and May 1986. Waddle Creek discharged about 190 tons/yr of suspended sediment at the streamflow-gaging station, 77 percent of which occurred in April and May 1986.

Seventy-five water samples were collected from 59 sites in the Hart Syncline area for laboratory analysis of dissolved constituents. Water in the areally continuous bedrock aquifers was a calcium bicarbonate type or calcium magnesium bicarbonate type near the recharge areas and a sodium bicarbonate type at locations further along the ground-water flow path. Water in local sandstone units in the upper Williams Fork Formation was a calcium bicarbonate type or a calcium sulfate type. Dissolved-solids concentrations for all bedrock-aquifer samples averaged about $830 \mathrm{mg} / \mathrm{L}$. Most of the water sampled from valley-fill aquifers, springs, and surface water contained dominant cations of calcium or magnesium, or both, and dominant anions of bicarbonate or sulfate, or both.

The results of this investigation are based on 6 weeks of well construction, followed by 15 months of hydrologic monitoring, sampling, and testing . Additional studies could be undertaken to better define the geology and hydrology of the Hart Syncline area, particularly in the western part of the study area. 


\section{SELECTED REFERENCES}

Bass, N.W., Eby, J.B., and Campbel1, M.R., 1955, Geology and mineral fuels of parts of Routt and Moffat Counties, Colorado: U.S. Geological Survey Bulletin 1027-D, p. 143-182.

Bouwer H., and Rice, R.C., 1976, A slug test for determining hydraulic conductivity of unconfined aquifers with completely or partially penetrating wells: Water Resources Research, v. 12, no. 3, p. 423-428.

Brownfield, M.E., and Johnson, E.A., 1986, A regionally extensive altered airfall ash for use in correlation of lithofacies in the Upper Cretaceous Williams Fork Formation, northeastern Piceance Creek and southern Sand Wash basins, Colorado, in Stone, D.S., ed., New interpretations of northwest Colorado geology: Denver, Rocky Mountain Association of Geologists, p. $165-169$.

Clark, G.M., and Williams, R.S., Jr., 1991, Identification of dissolved constituent sources in mine-site ground water using batch mixing: Water Resources Bulletin, v. 27, no. 1, p. 93-100.

Colorado Department of Health, 1979, Regulations establishing basic standards and an antidegradation standard and establishing a system for classifying state waters, for assigning standards, and for granting temporary modifications: Denver, Water Quality Control Commission, $41 \mathrm{p}$. 1981, Colorado primary drinking-water regulations: Denver, Water Quality Control Division, $89 \mathrm{p}$.

Colorado State University, Department of Atmospheric Science, Colorado Climate Center, compiler, 1984, Colorado average annual precipitation 1951-1980: Denver, Colorado, U.S. Geological Survey map, scale 1:500,000.

Cooper, H.H., Jr., Bredehoeft, J.D., and Papadopulos, I.S., 1967, Response of a finite-diameter well to an instantaneous charge of water: Water Resources Research, v. 3, no. 1, p. 263-269.

Cooper, H.H., Jr., and Jacob, C.E., 1946, A generalized graphical method for evaluating formation constants and summarizing well-field history:

Transactions of the American Geophysical Union, v. 27, no. 4, p. 526-534.

Ferris, J.G., Knowles, D.B., Brown, R.H., and Stallman, R.W., 1962, Theory of aquifer tests: U.S. Geological Survey Water-Supply Paper 1536-E, 174 p.

Freeze, R.A., and Cherry, J.A., 1979, Groundwater: Englewood Cliffs, N.J., Prentice-Hall, Inc., 604 p.

Giles, T.F., and Brogden, R.E., 1978, Selected hydrologic data, Yampa River basin, and parts of the White River basin, northwestern Colorado and south-central Wyoming: U.S. Geological Survey Open-File Report 78-23, $91 \mathrm{p}$.

Hancock, E.T., 1925, Geology and coal resources of the Axial and Monument Butte quadrangles, Moffat County, Colorado: U.S. Geological Survey Bulletin 757, $134 \mathrm{p}$.

Hem, J.D., 1985, Study and interpretation of the chemical characteristics of natural water ( 3 rd ed.): U.S. Geological Survey Water-Supply Paper 2254, $263 \mathrm{p}$.

Jacob, C.E., and Lohman, S.W., 1952, Nonsteady flow to a well of constant drawdown in an extensive aquifer: American Geophysical Union Transactions, v. 33, p. 559-569.

Johnson, E.A., and Brownfield, M.E., 1984, Selected references on the geology of the Yampa coal field and Sand Wash basin, Moffat, Routt, and Rio Blanco Counties, Colorado: U.S. Geological Survey Open-File Report 84-769, 42 p. 
Lohman, S.W., 1979, Ground-water hydraulics: U.S. Geological Survey Professional Paper 708, 70 p.

Maura, W.S., 1982, Water-quality data for streams in the southern Yampa River basin, northwestern Colorado: U.S. Geological Survey Open-File Report 82-1017, 112 p.

1985, Selected trace-element data for streams in the southern Yampa River basin, northwestern Colorado: U.S. Geological Survey Open-File Report 85-192, $154 \mathrm{p}$.

Meyer, R.F., 1977, Geophysical logs of 22 holes drilled in 1976 in the Yampa coal field, Moffat County, northwestern Colorado: U.S. Geological Survey Open-File Report 77-118, 6 p.

1978, Geophysical logs of 20 holes drilled in 1977 in the Yampa coal field, Hamilton, Horse Gulch, and Pagoda quadrangles, Moffat County, Colorado: U.S. Geological Survey Open-File Report 78-366, 51 p.

Meyer, R.F., and Brown, R.R., 1982, Geophysical logs of nine holes drilled in 1978 in the Yampa coal field, Hamilton and Pagoda quadrangles, Moffat County, Colorado: U.S. Geological Survey Open-File Report 82-475, 32 p.

Papadopulos, I.S., and Cooper, H.H., Jr., 1967, Drawdown in a well of large diameter: Water Resources Research, v. 3, no. 1, p. 241-244.

Piper, A.M., Garrett, A.A., and others, 1953, Native and contaminated ground waters in the Long Beach-Santa Ana area, California: U.S. Geological Survey Water-Supply Paper $1136,320 \mathrm{p}$.

Reed, J.E., 1980, Type curves for selected problems of flow to wells in confined aquifers; U.S. Geological Survey, Techniques of Water-Resources Investigations, Book 3, Chapter B3, 106 p.

Robson, S.G., and Stewart, Michael, 1990, Geohydrologic evaluation of the upper part of the Mesaverde Group, northwestern Colorado; U.S. Geological Survey Water-Resources Investigations Report 90-4020, 125 p.

Theis, C.V., 1935, The relation between the lowering of the piezometric surface and the rate and duration of discharge of a well using groundwater storage: Transactions of the American Geophysical Union, v. 16, p. 519-524.

Tweto, Ogden, compiler, 1976, Geologic map of the Craig $1^{\circ} \times 2^{\circ}$ Quadrangle northwestern Colorado: U.S. Geological Survey Miscellaneous Investigations Map I-972, scale $1: 250,000,1$ sheet.

U.S. Environmental Protection Agency, 1986a, Maximum contaminant levels (subpart B of part 141, National primary drinking-water regulations): U.S. code of Federal Regulations, Title 40, Parts 100 to 149 , revised as of July 1, 1986, p. 524-528.

1986b, Secondary maximum contaminant levels (section 143.3 of part 143, National secondary drinking-water regulations): U.S. Code of Federal Regulations, Title 40, parts 100 to 149, revised as of July 1, 1986, p. 587-590.

U.S. Geological Survey, 1986a, Water resources data, Colorado, water year 1986, v. 2: U.S. Geological Survey Water-Data Report C0-86-2, 434 p. 1986b, National water summary 1986--Hydrologic events and ground-water quality: U.S. Geological Survey Water-Supply Paper 2325, p. 553.

Wentz, D.A., and Steele, T.D., 1980, Analys is of stream quality in the Yampa River basin, Colorado and Wyoming: U.S. Geological Survey WaterResources Investigations 80-8, $161 \mathrm{p}$. 

SUPPLEMENTAL INFORMATION 
We11-Completion Diagrams and Generalized Geologic Logs for Wells Completed in Bedrock Aquifers

Well-completion diagrams and generalized geologic logs for wells completed in bedrock aquifers are shown in figures 26 through 34 . Only generalized geologic logs are shown in order to safeguard proprietary coal-resource information. Individual coal beds, in particular, are not delineated. 


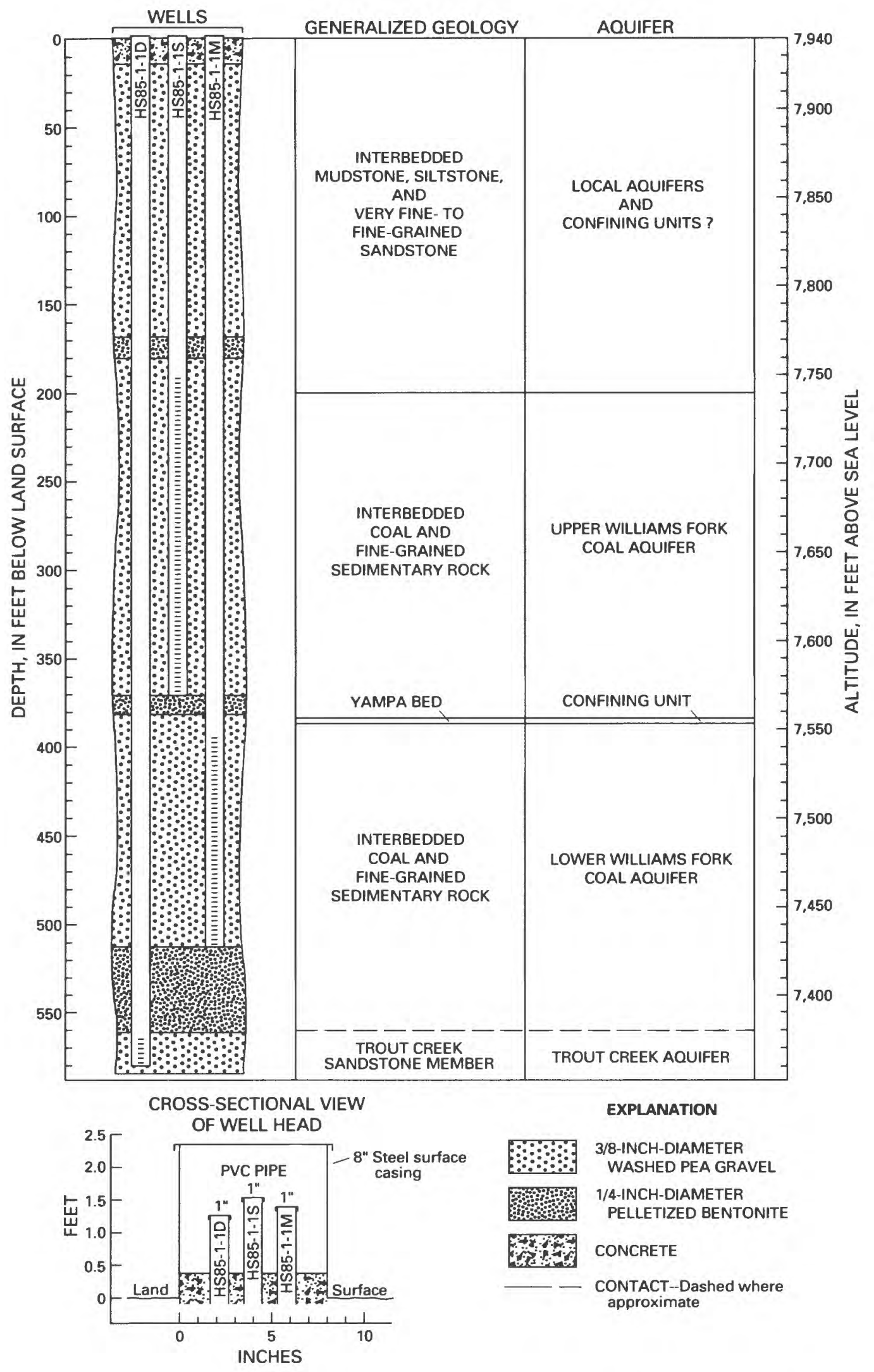

Figure 26.--Well completion and generalized geologic log for borehole HS85-1. 


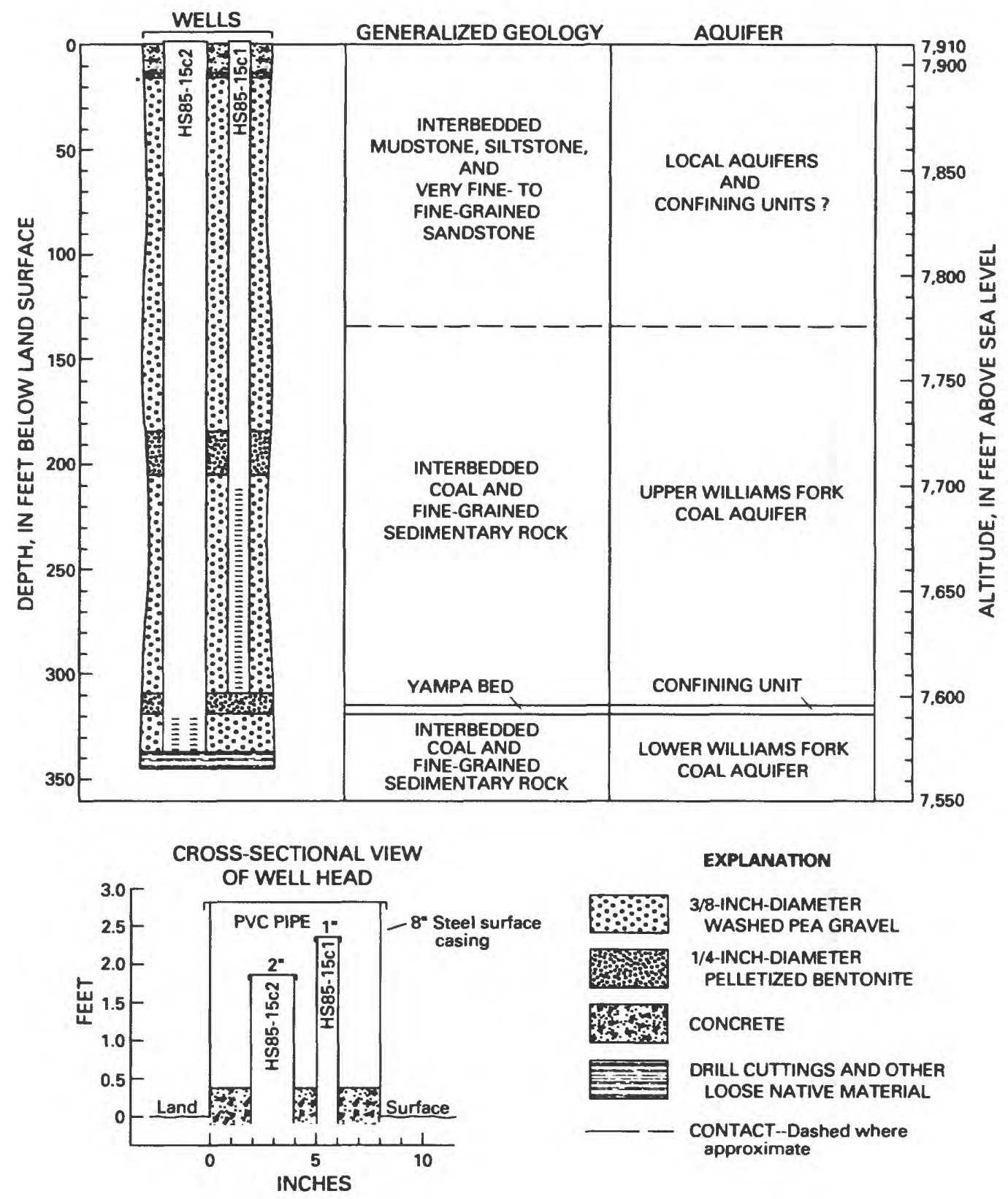

Figure 27.--Well completion and generalized geologic log for borehole HS85-15c. 


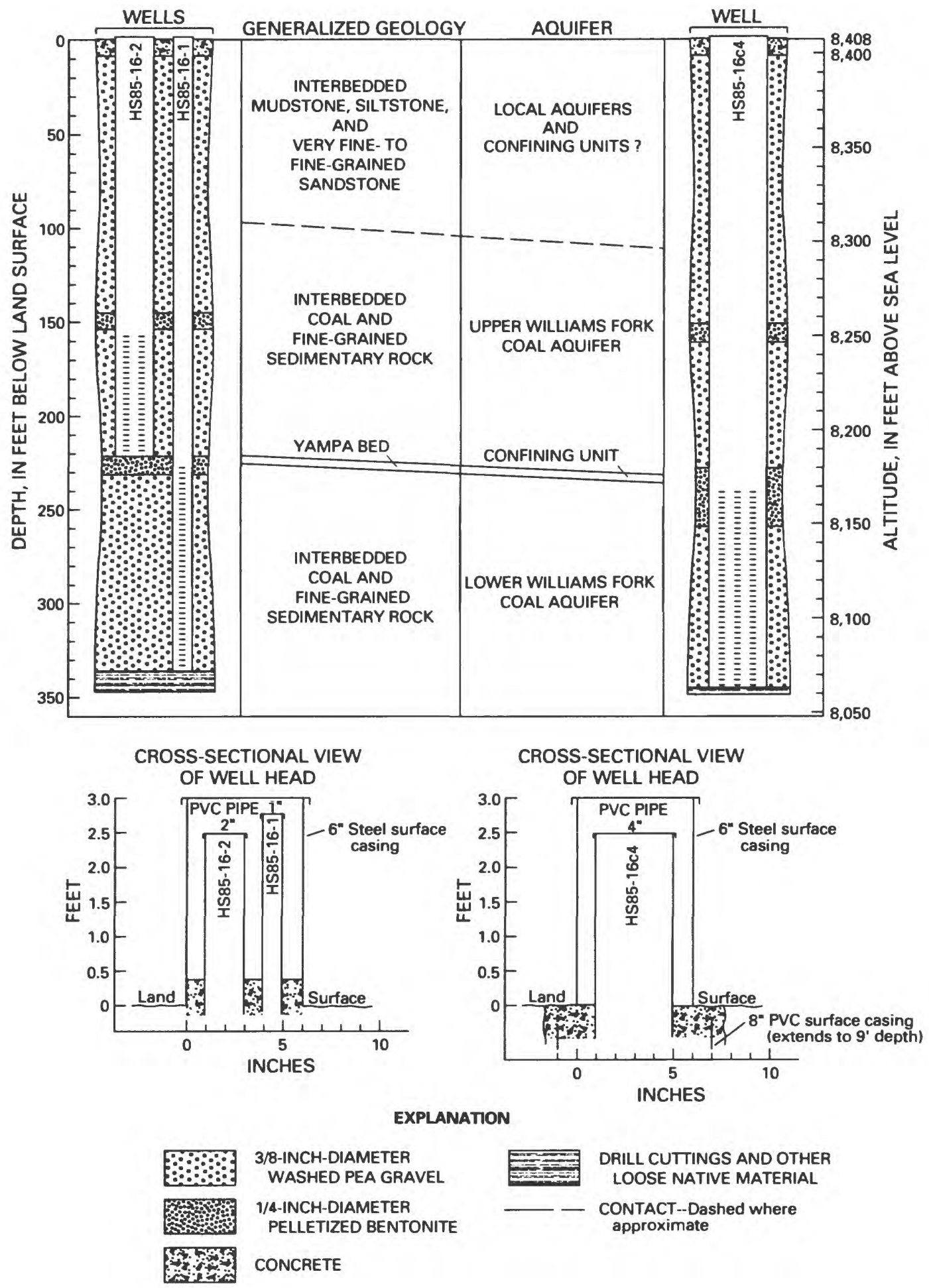

Figure 28.--Well completion and generalized geologic log for boreholes HS85-16 and HS85-16c. 


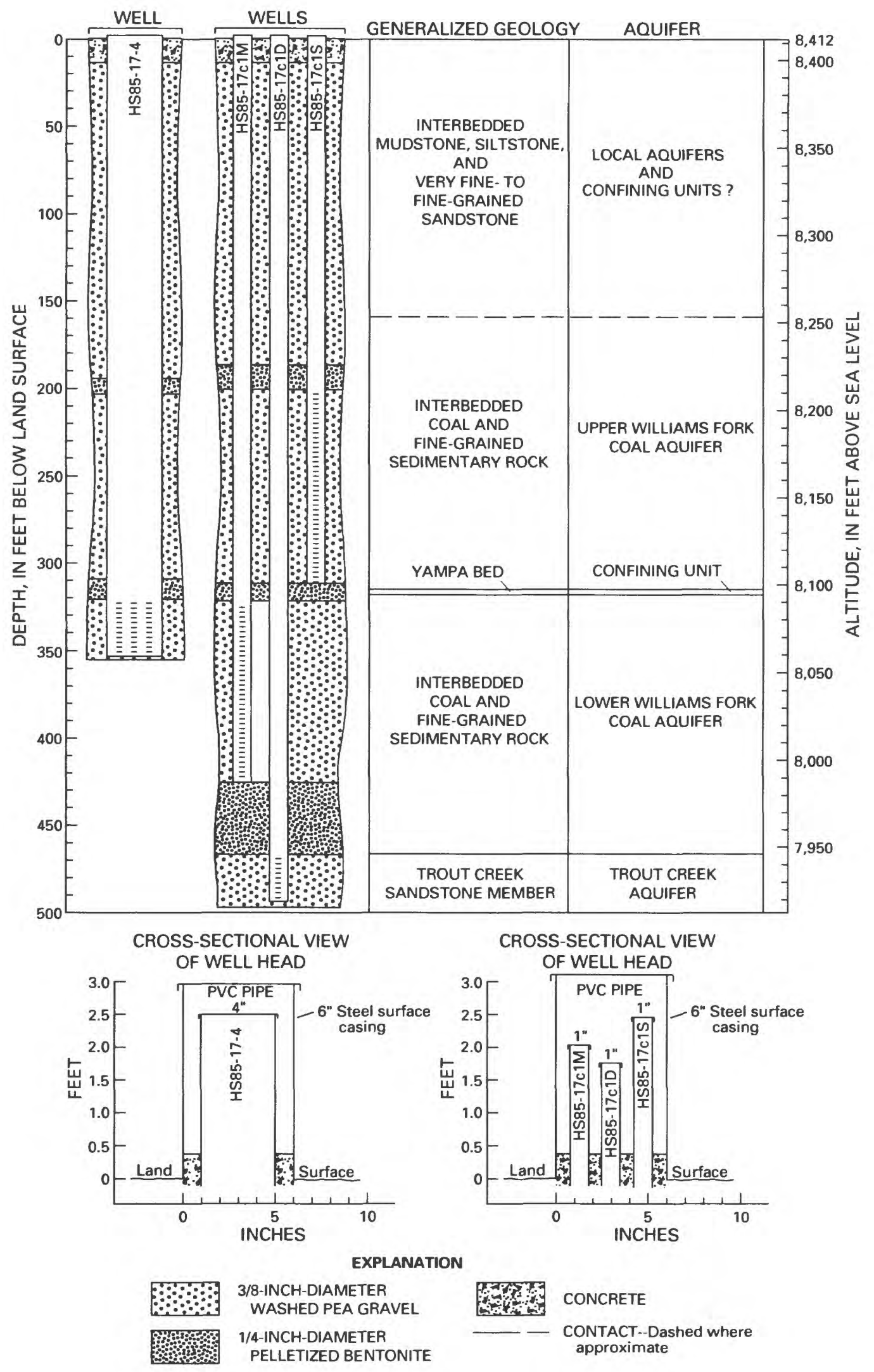

Figure 29.--Well completion and generalized geologic log for boreholes HS85-17 and HS85-17c. 


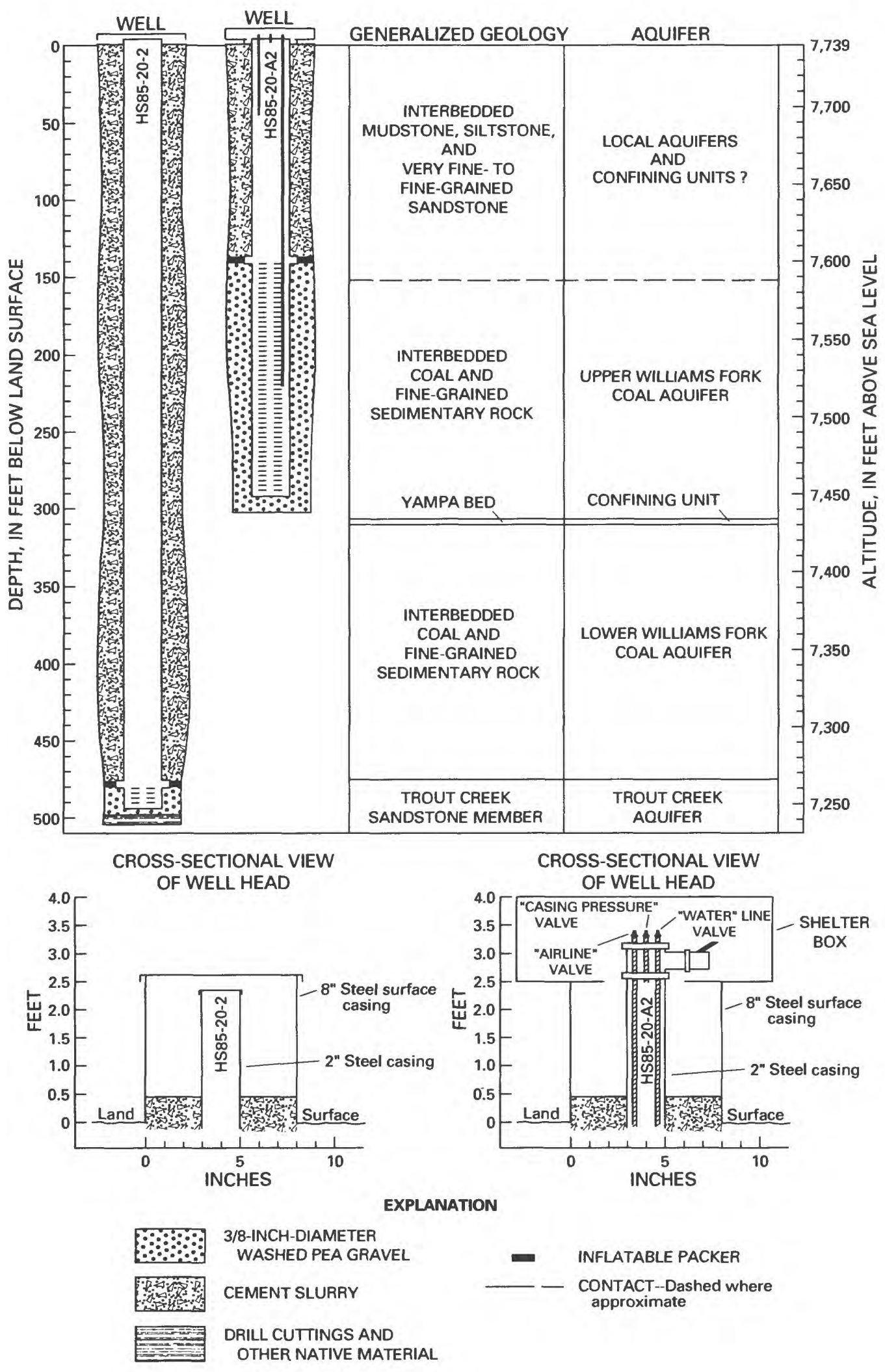

Figure 30.--Well completion and generalized geologic $\log$ for boreholes HS85-20 and HS85-20A. 


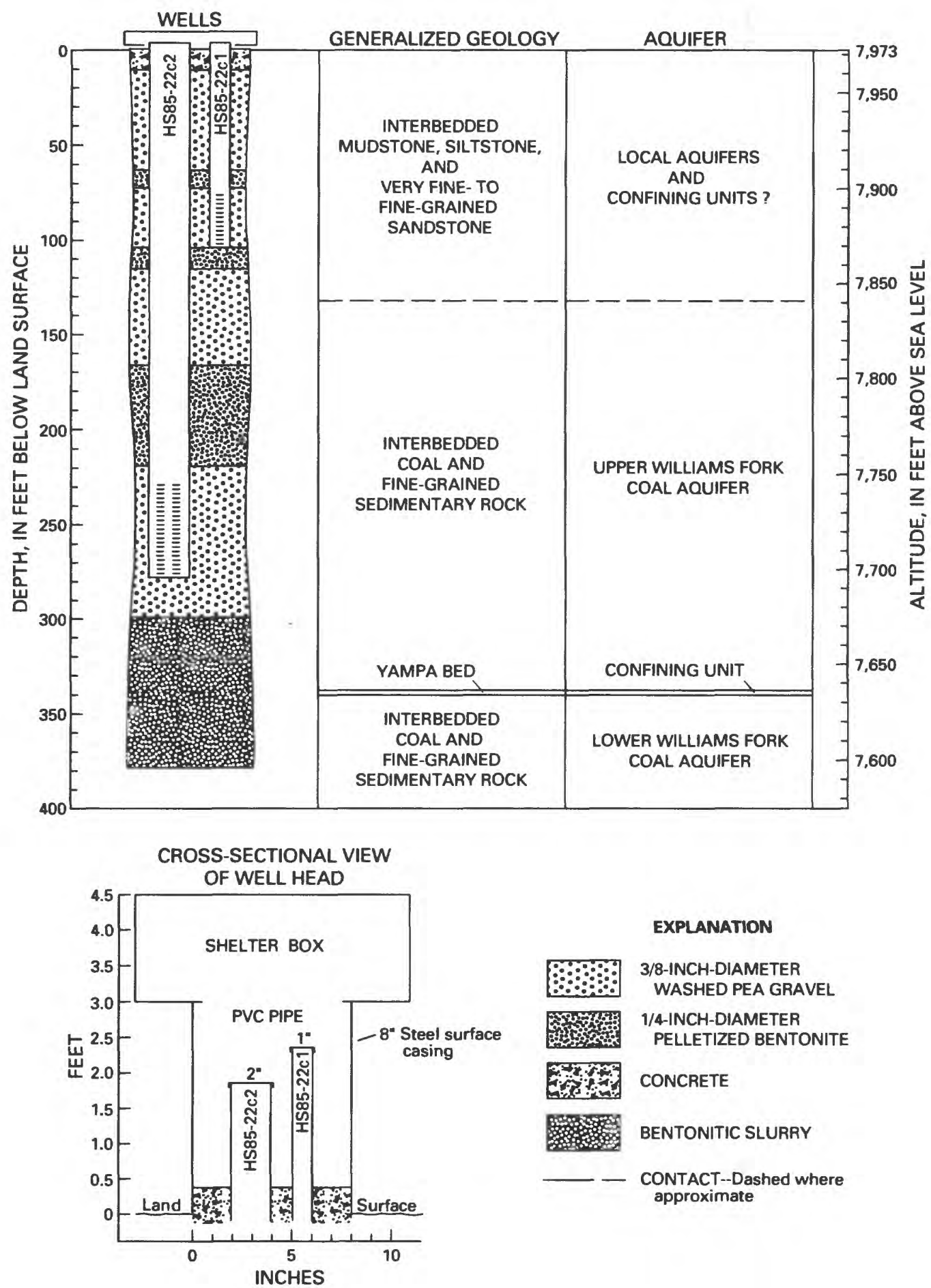

Figure 31.--Well completion and generalized geologic $\log$ for borehole HS85-22c. 

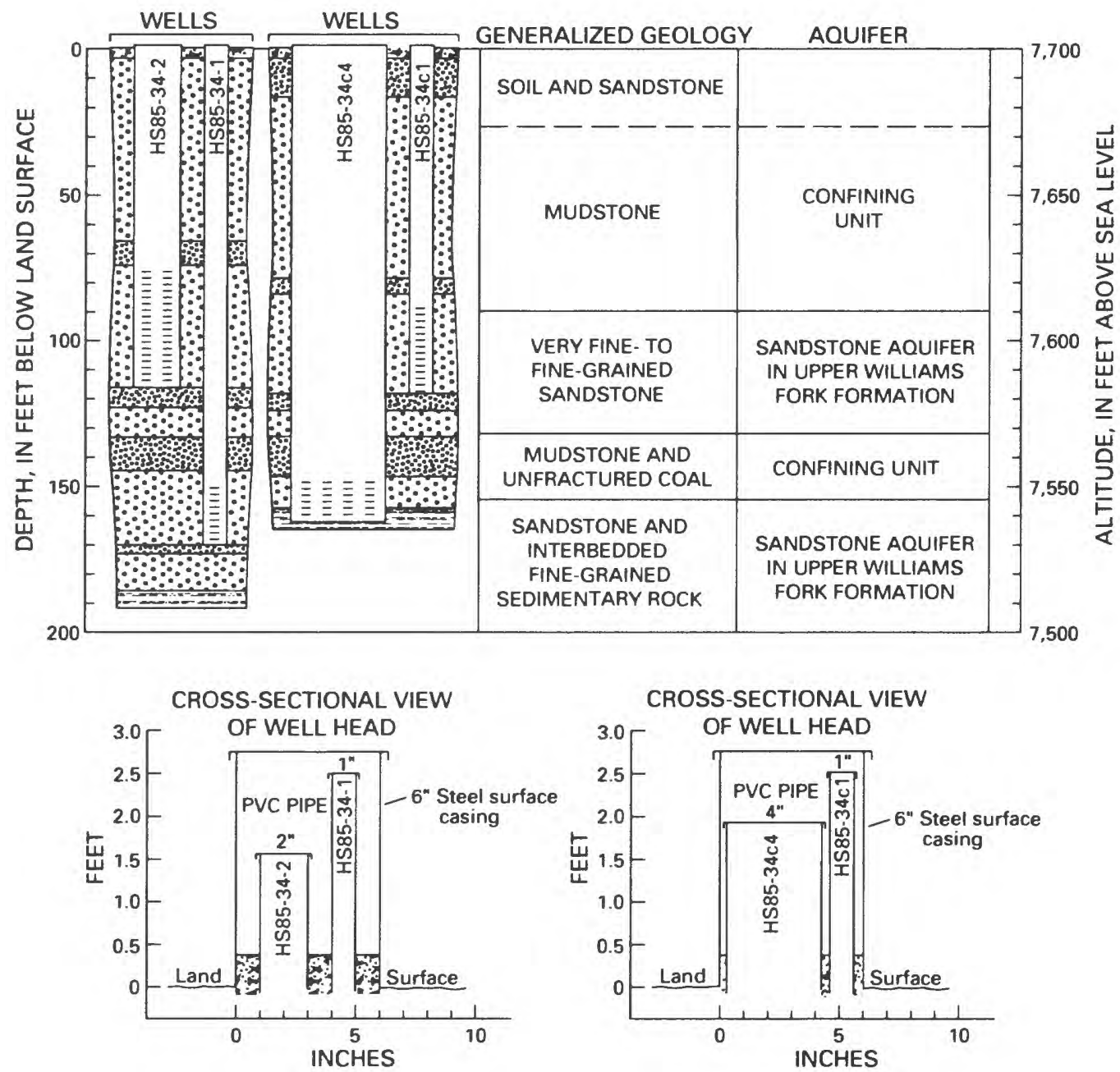

EXPLANATION

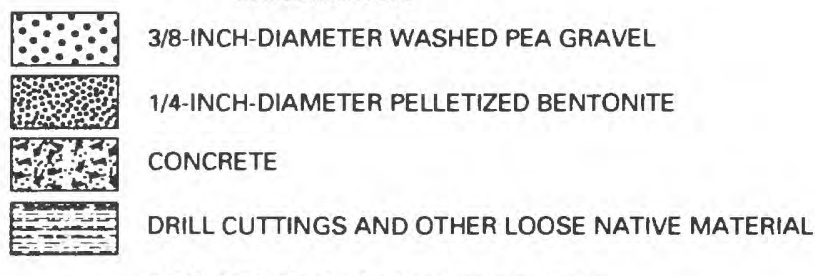

- CONTACT--Dashed where approximate

Figure 32.--Well completion and generalized geologic log for boreholes HS85-34 and HS85-34c. 


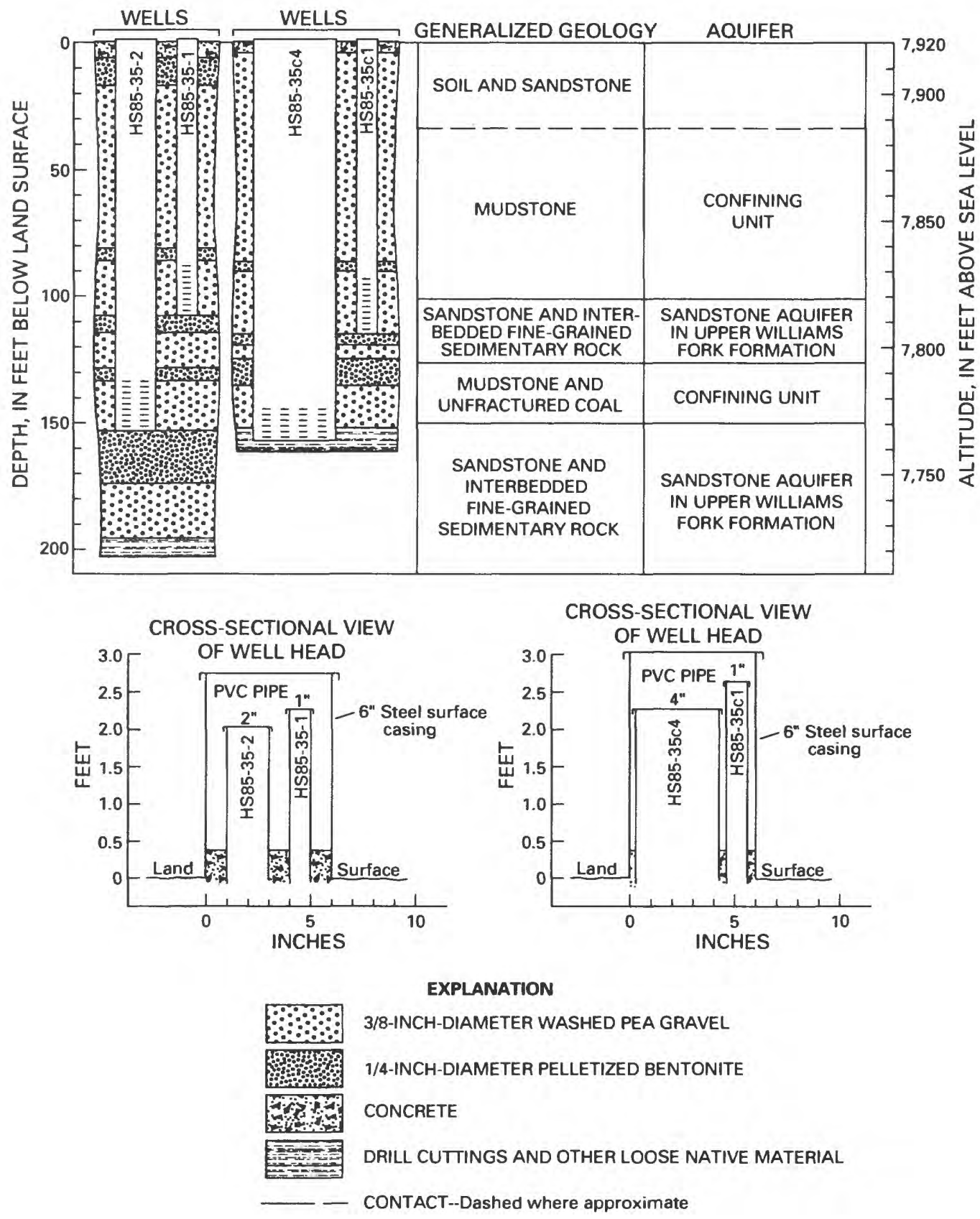

Figure 33.--Well completion and generalized geologic $\log$ for boreholes HS85-35 and HS85-35c. 


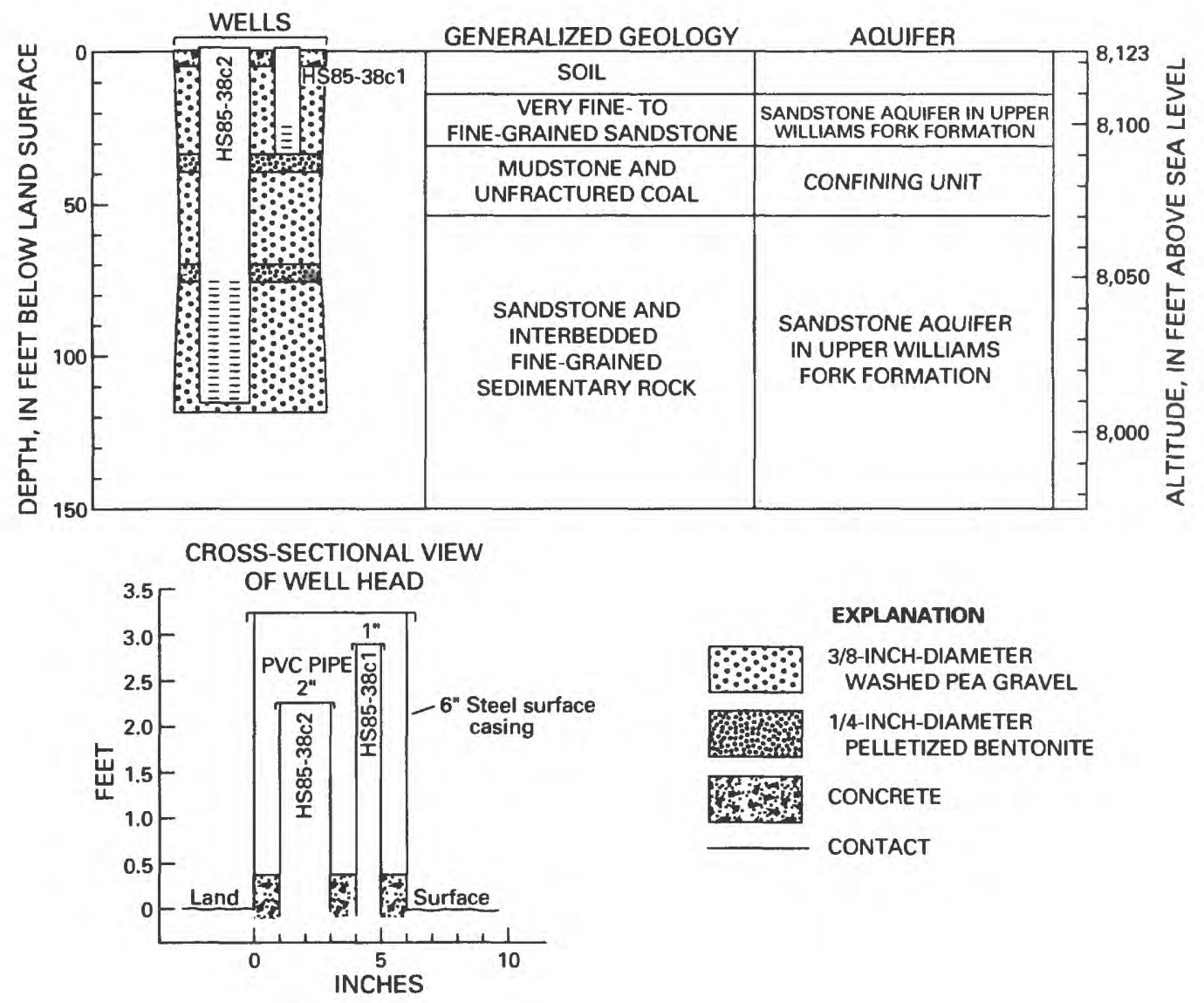

Figure 34.--Well completion and generalized geologic log for borehole HS85-38c. 
Water-Level Hydrographs for Wells Completed in Bedrock Aquifers

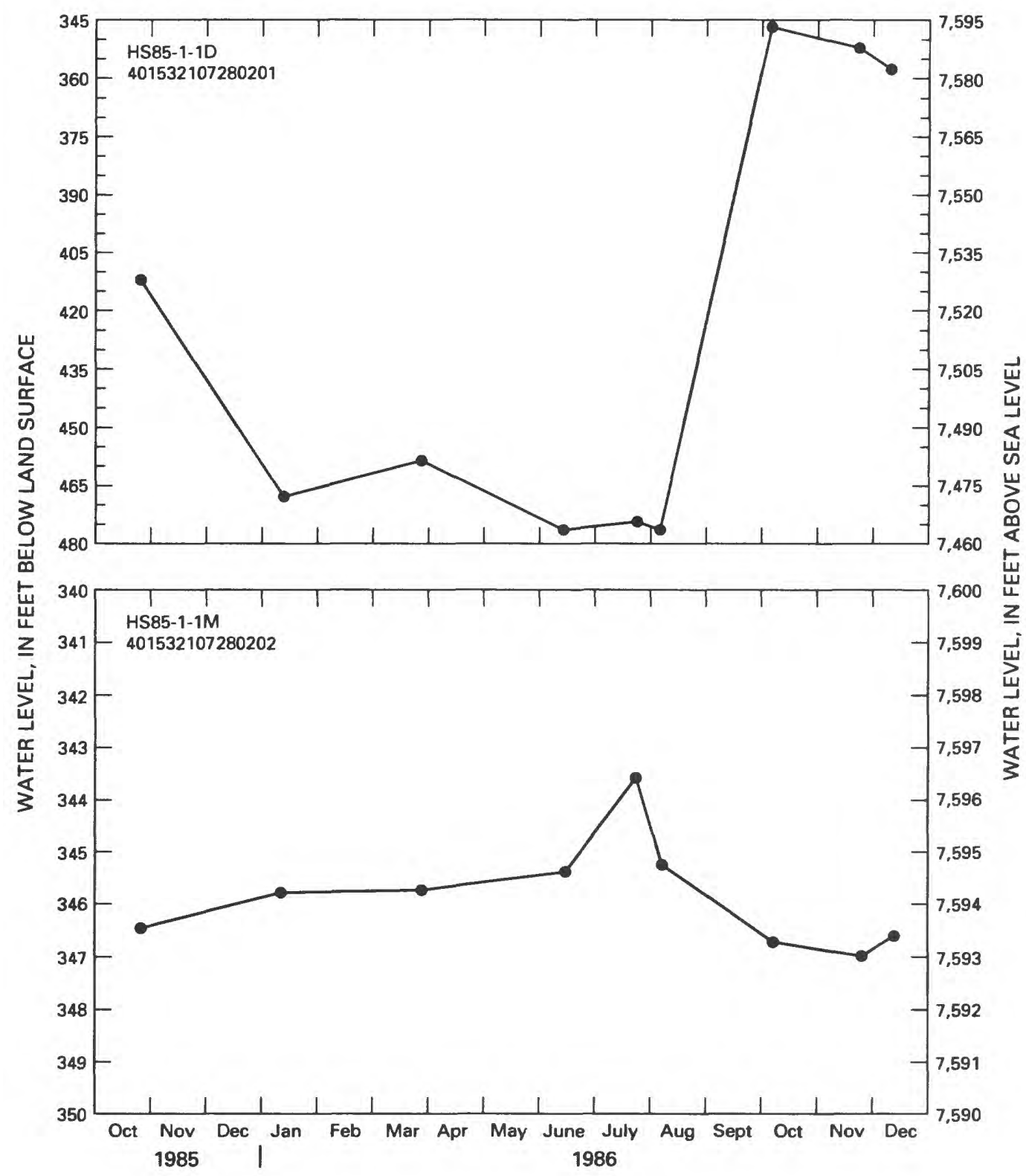

Figure 35A.--Water-level hydrographs for wells completed in bedrock aquifers. 


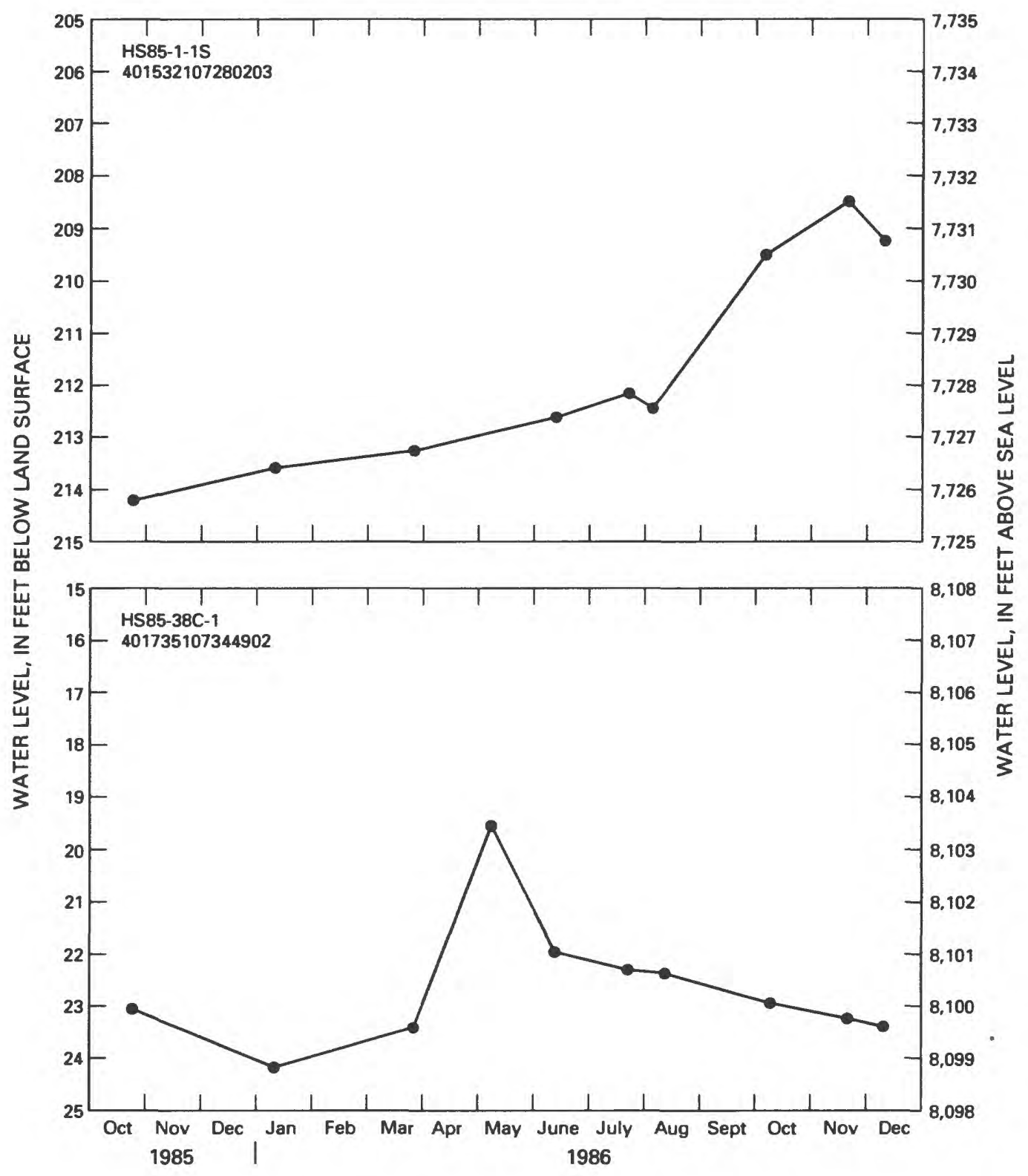

Figure 35B.--Water-level hydrographs for wells completed in bedrock aquifers--Continued. 


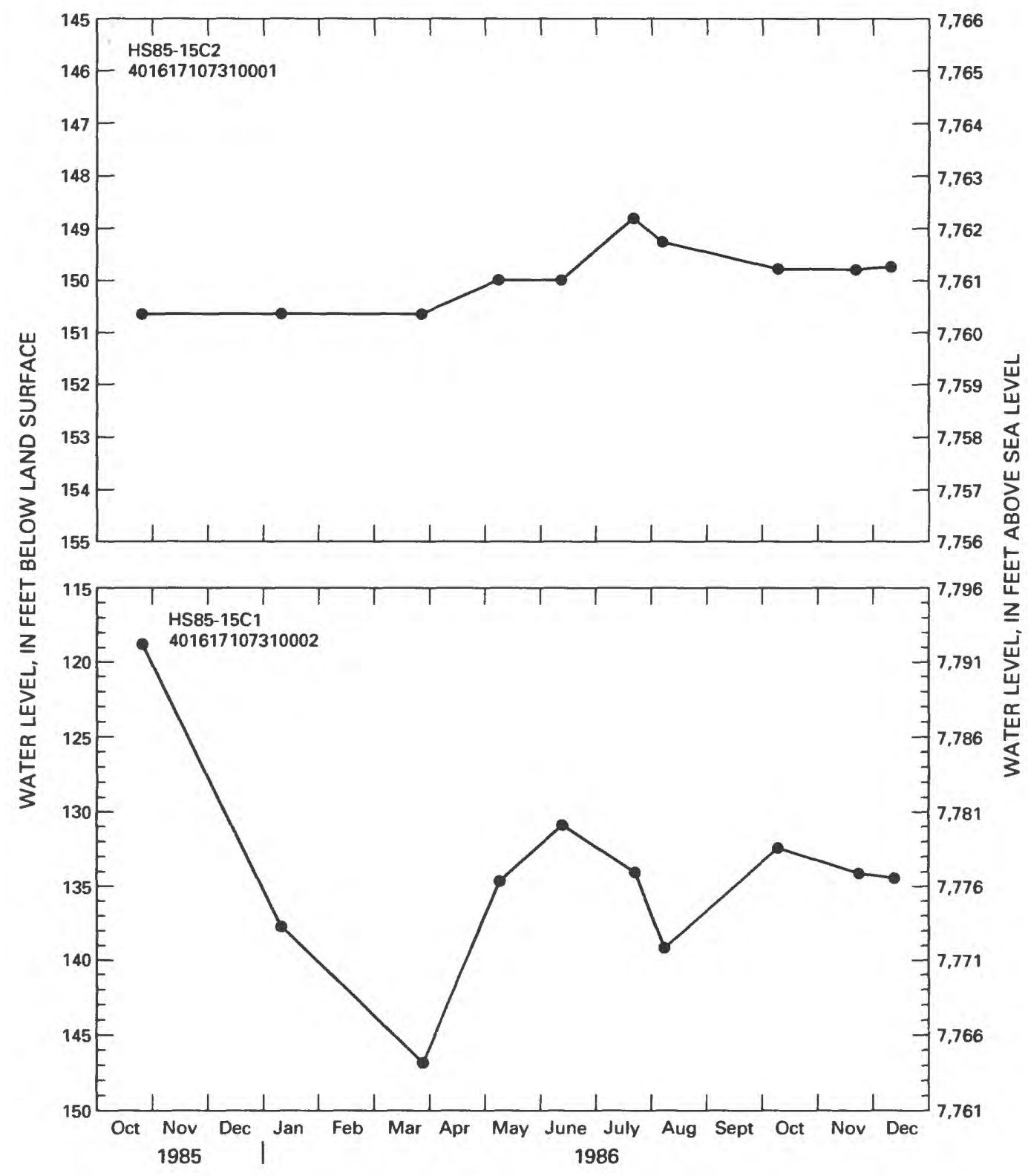

Figure 35C.--Water-level hydrographs for wells completed in bedrock aquifers--Continued. 


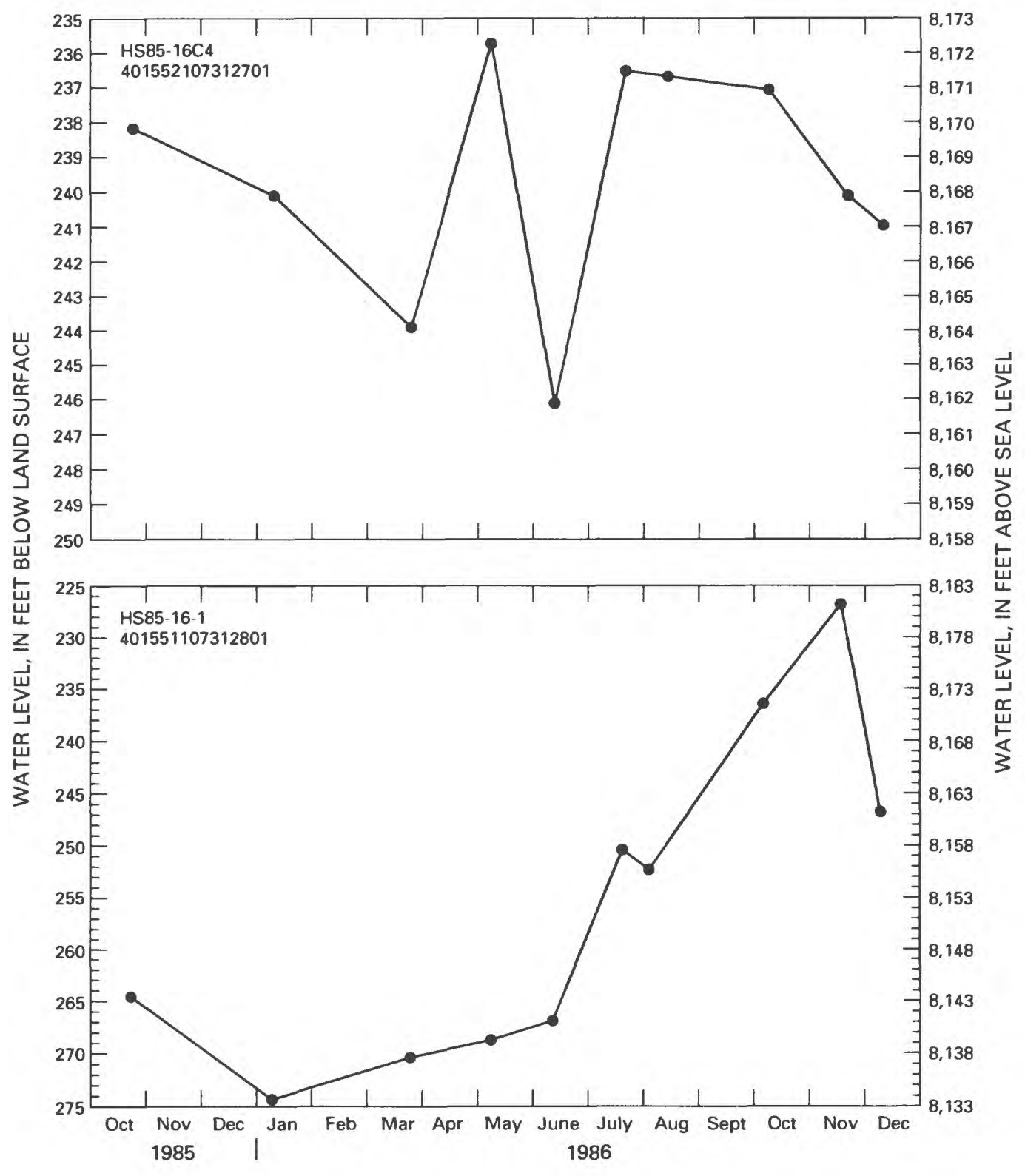

Figure 35D.--Water-level hydrographs for wells completed in bedrock aquifers--Continued. 


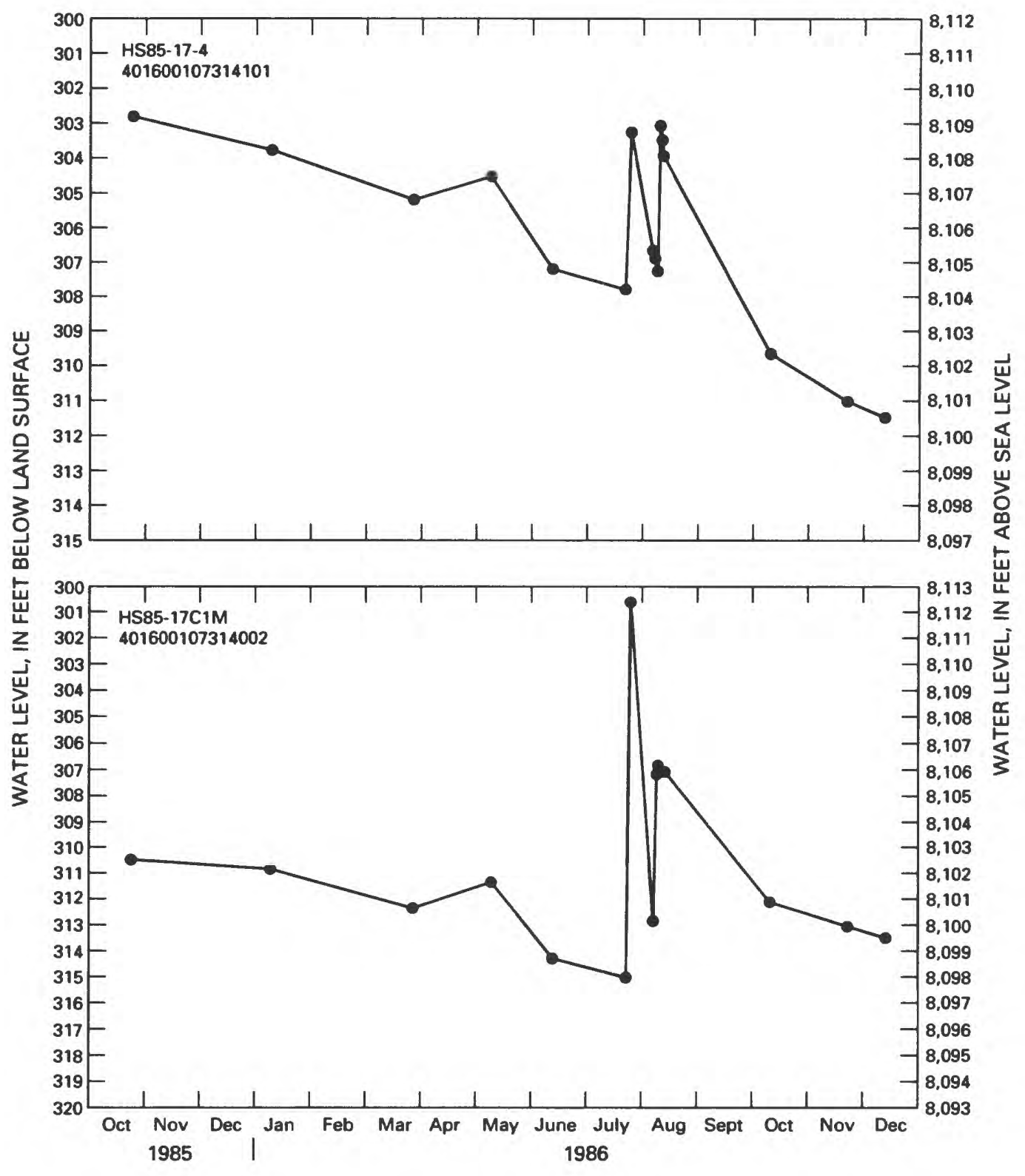

Figure 35E.--Water-level hydrographs for wells completed in bedrock aquifers--Continued. 


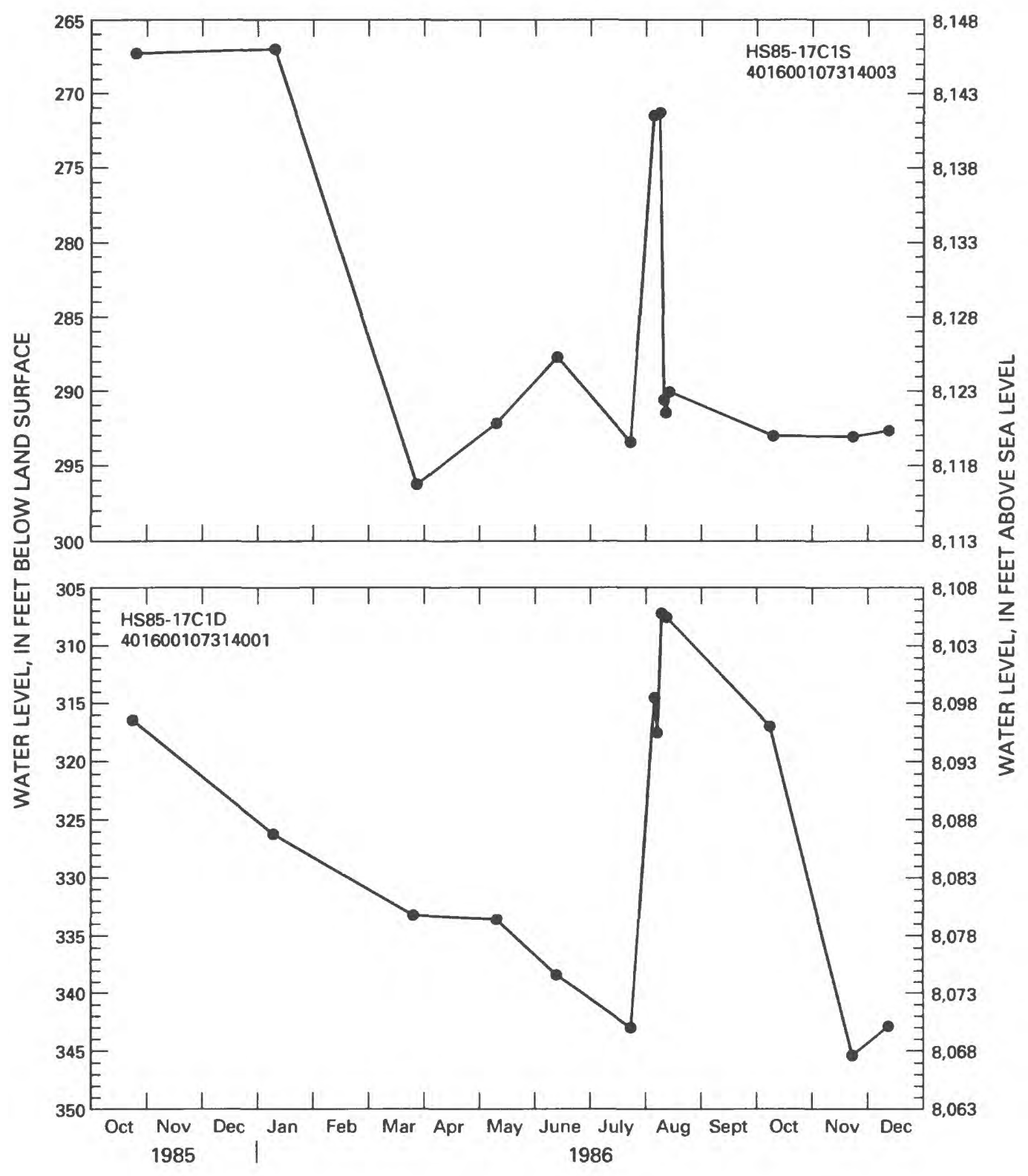

Figure 35F.--Water-1evel hydrographs for wells completed in bedrock aquifers--Continued. 


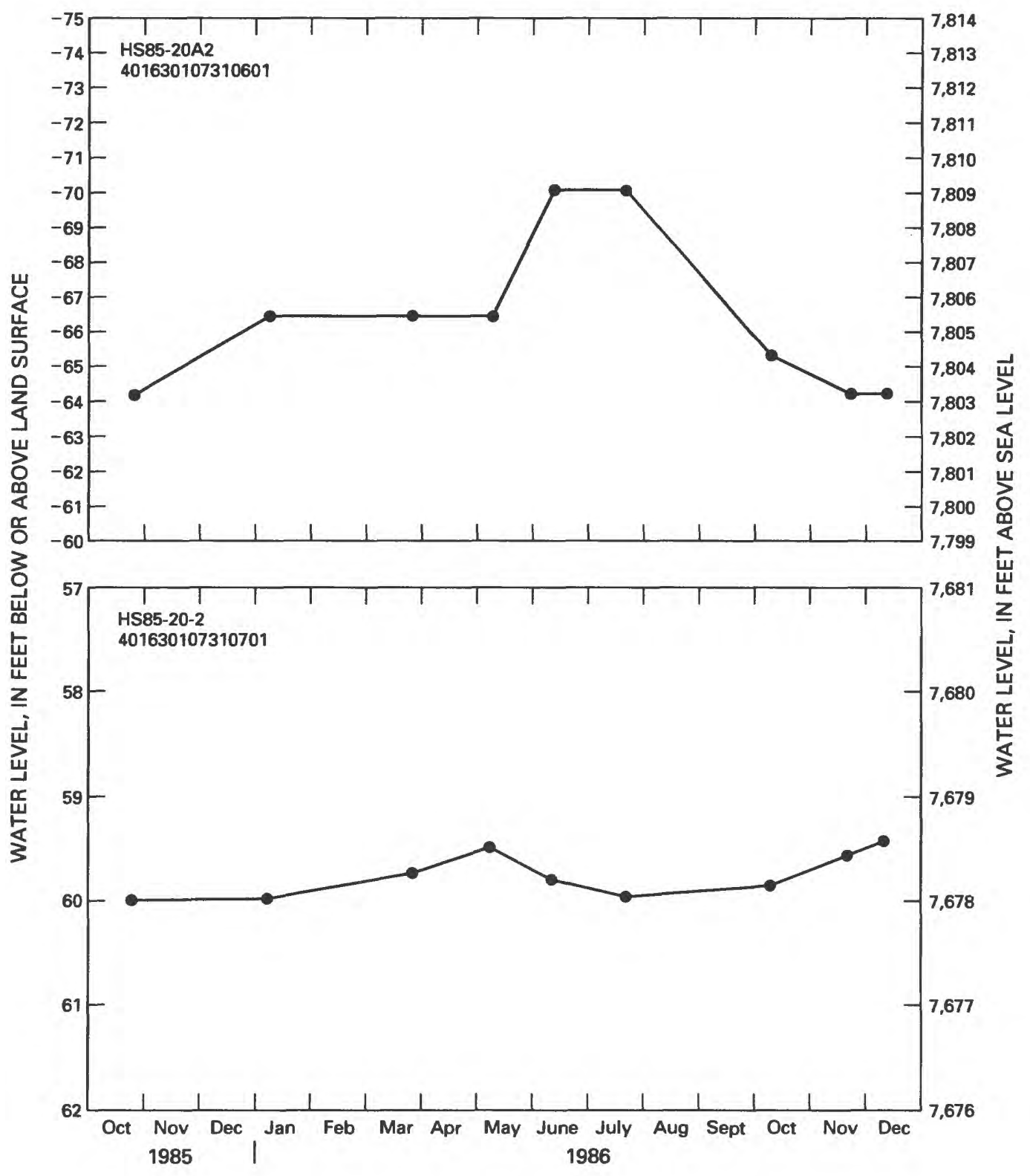

Figure 35G.--Water-level hydrographs for wells completed in bedrock aquifers--Continued. 


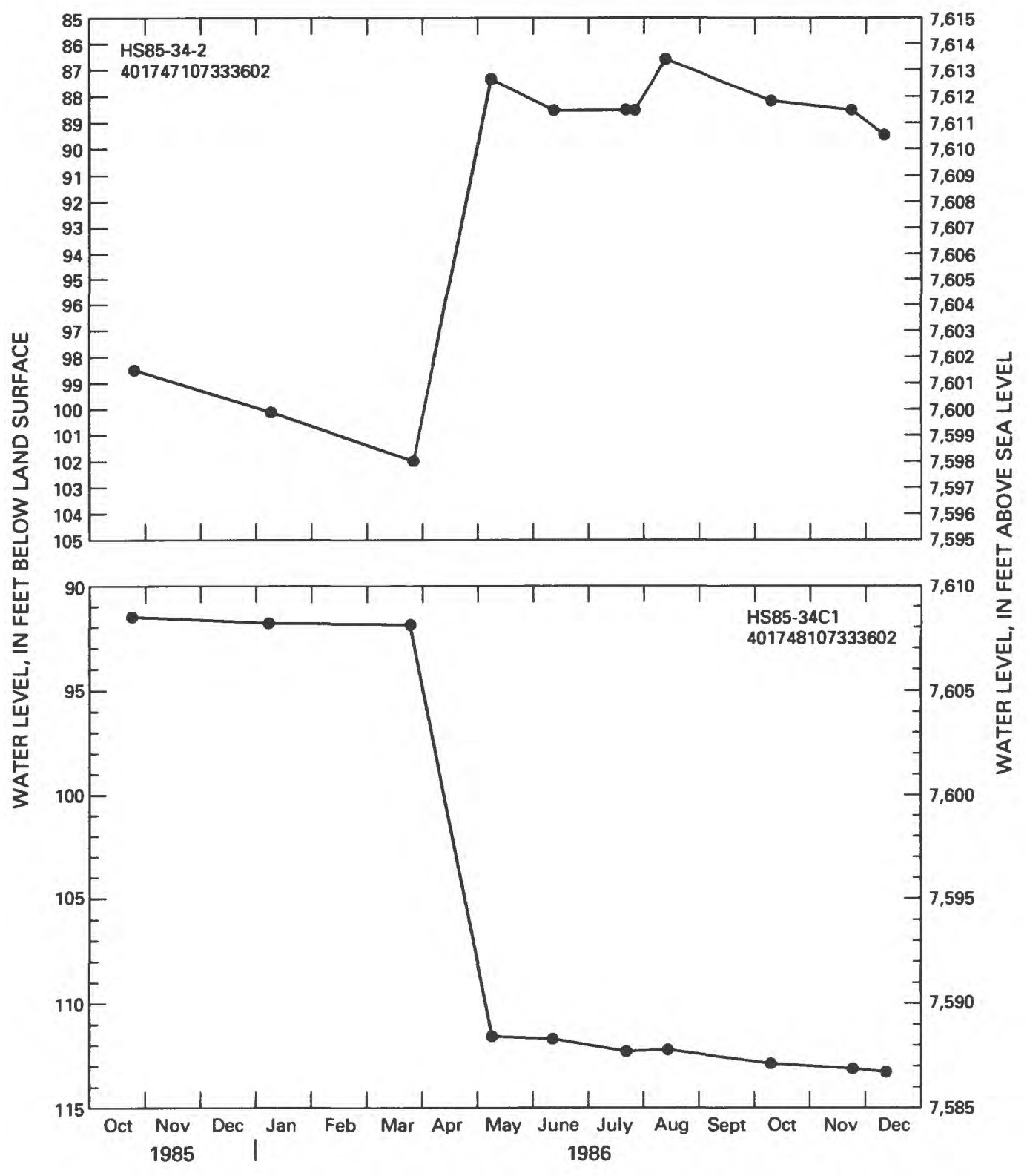

Figure 35H.--Water-level hydrographs for wells completed in bedrock aquifers--Continued. 


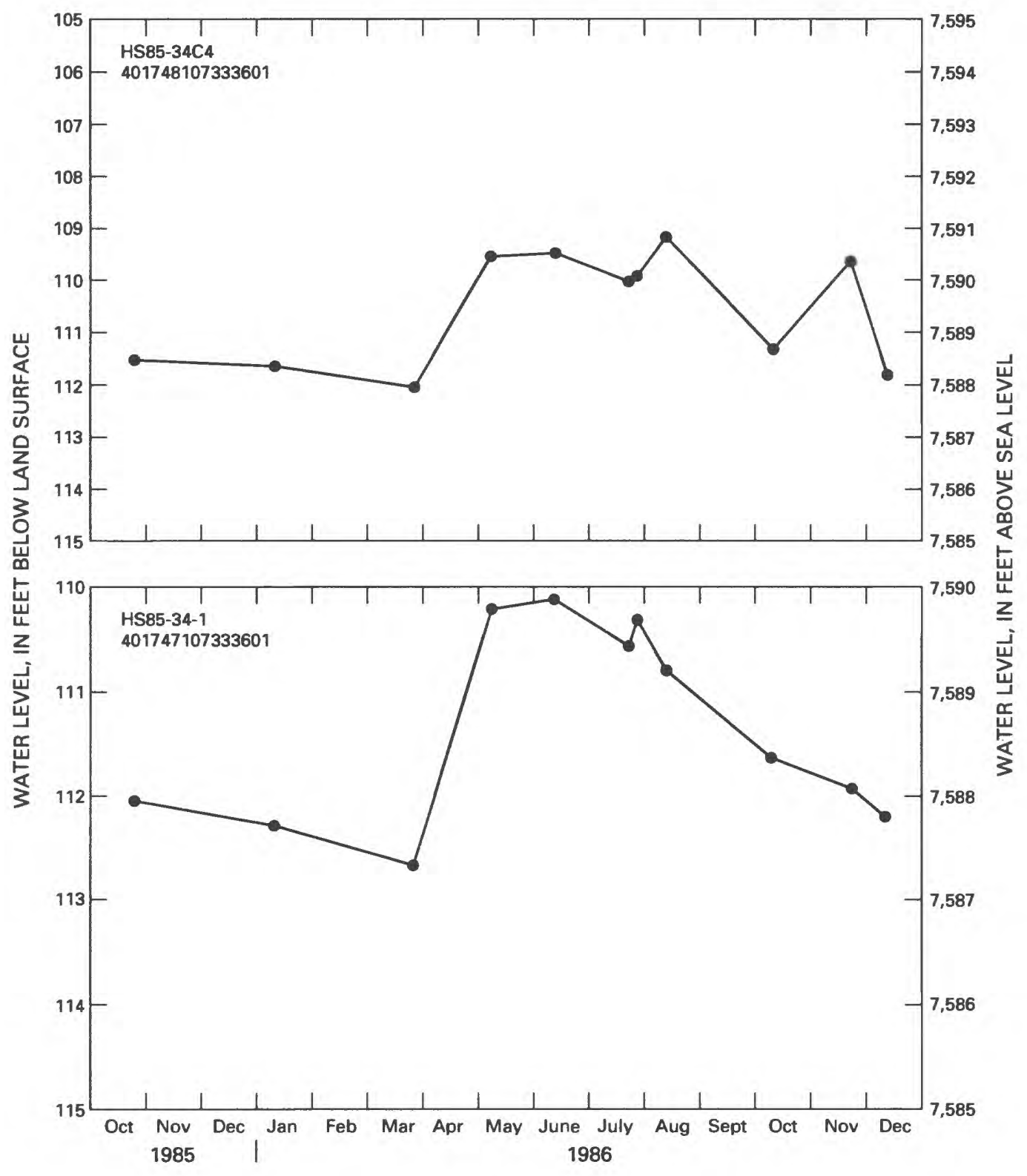

Figure 35I.--Water-level hydrographs for wells completed in bedrock aquifers--Continued. 


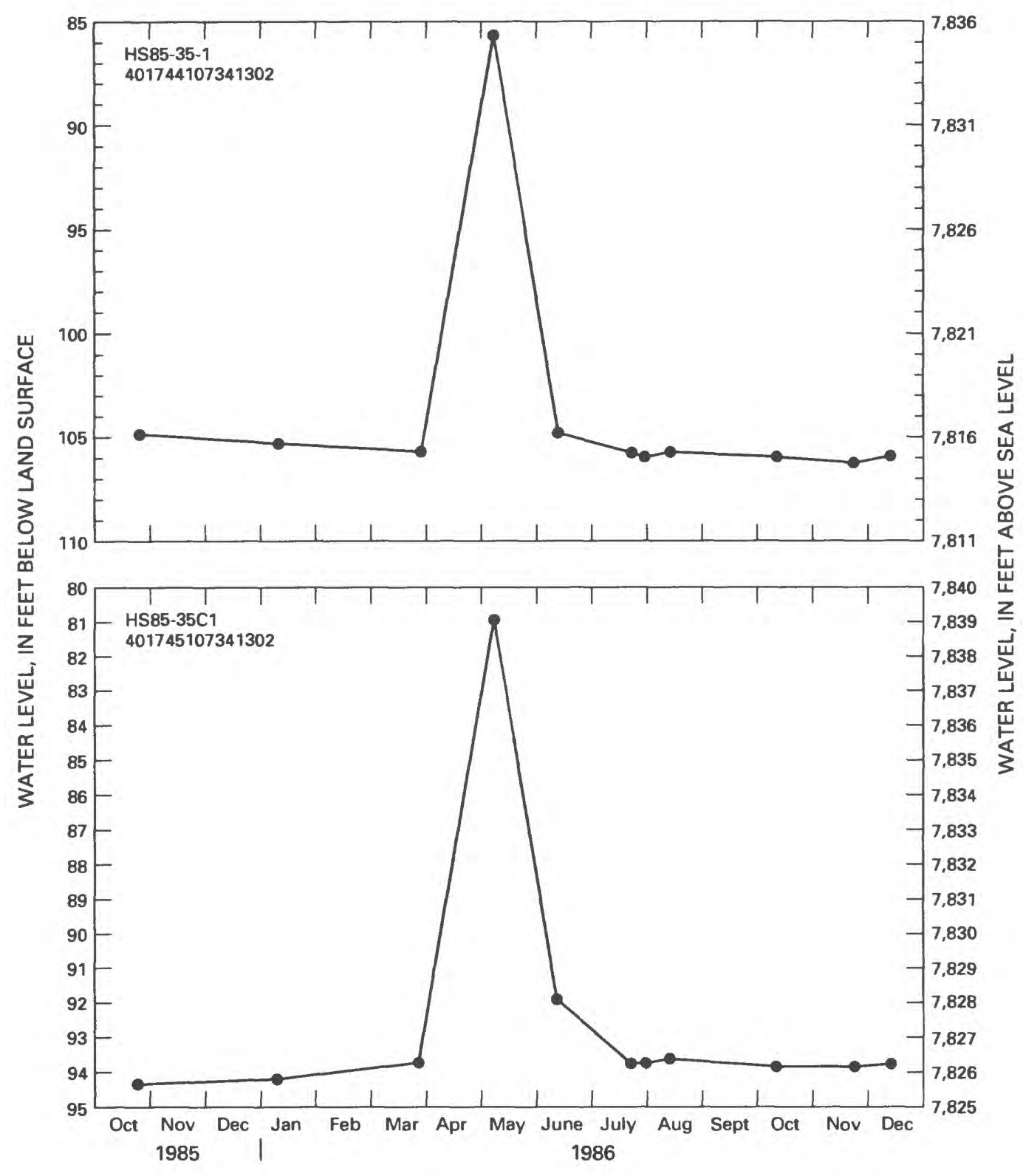

Figure 35J.--Water-level hydrographs for wells completed in bedrock aquifers--Continued. 


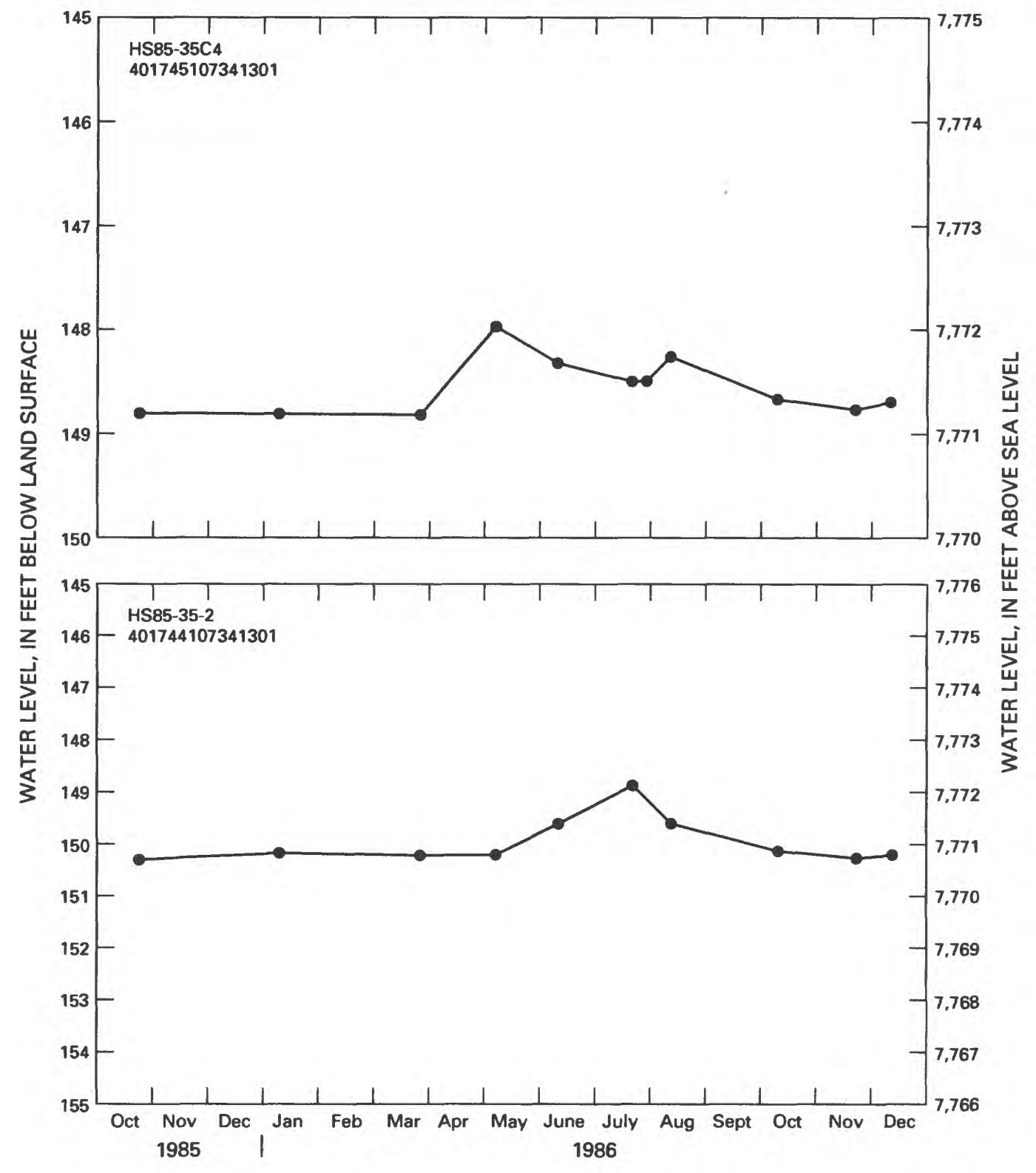

Figure 35K.--Water-level hydrographs for wells completed in bedrock aquifers--Continued. 


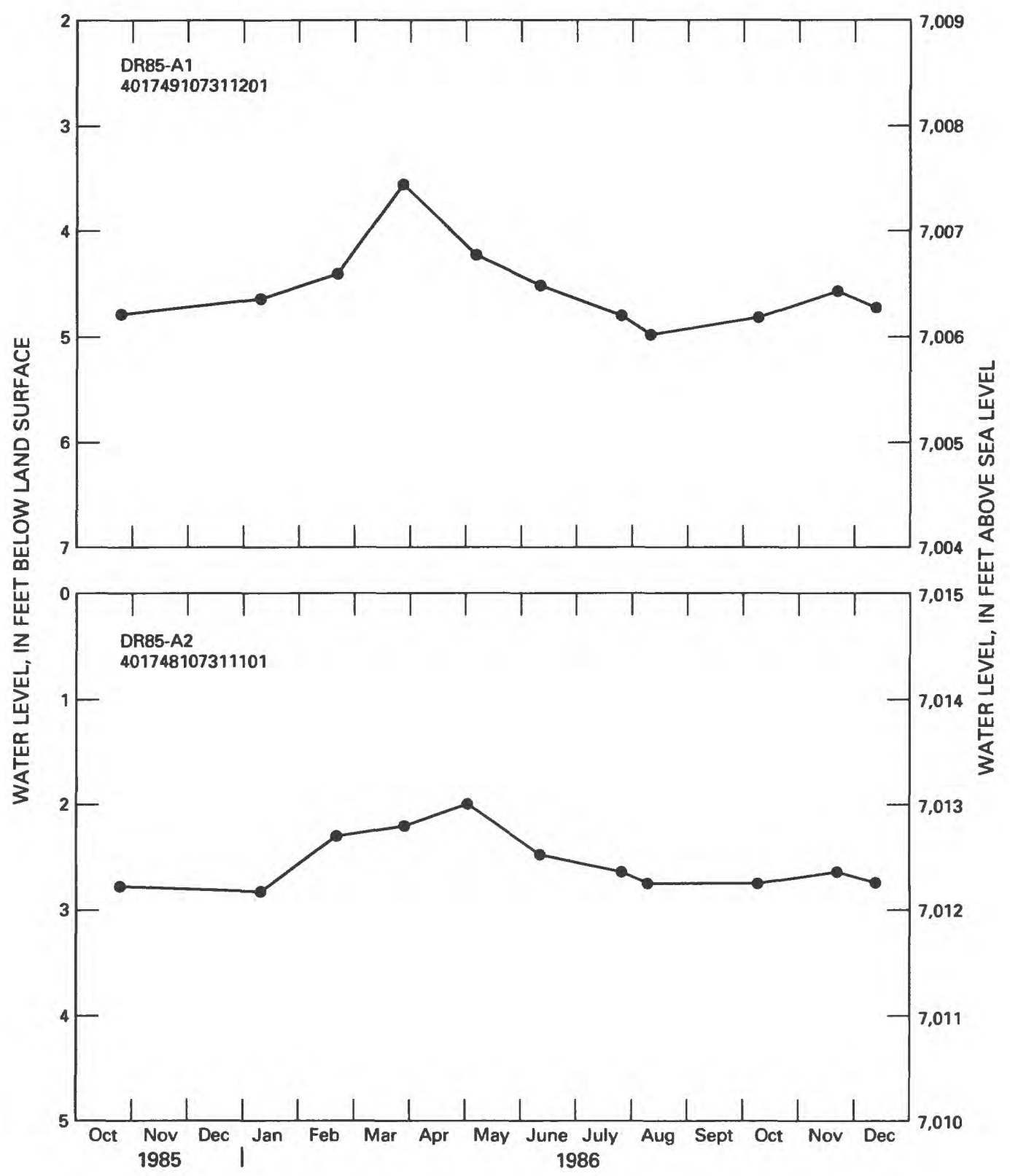

Figure 36A.--Water-level hydrographs for wells completed in valley-fill aquifers. 


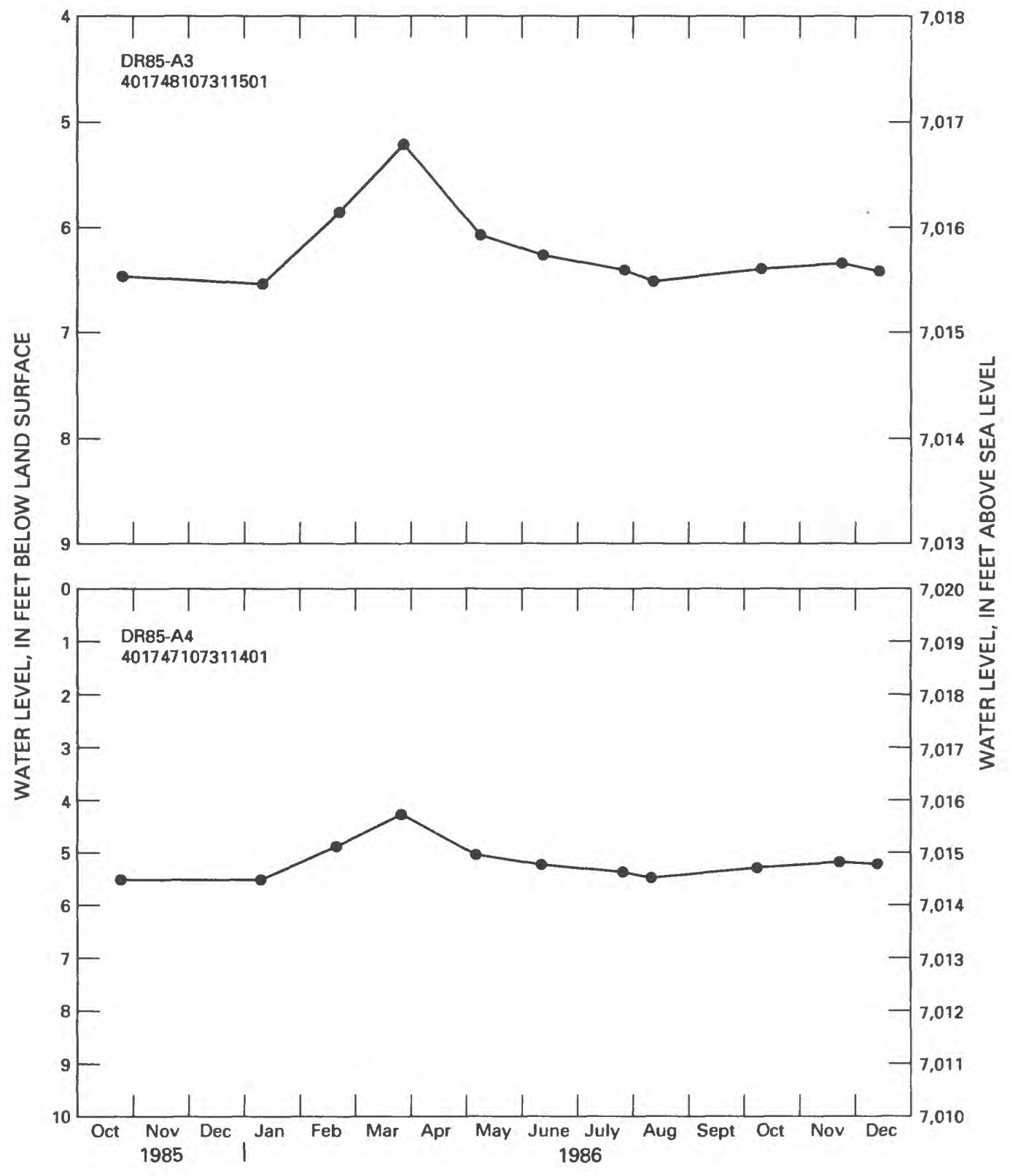

Figure 36B.--Water-level hydrographs for wells completed in valley-fill aquifers--Continued. 


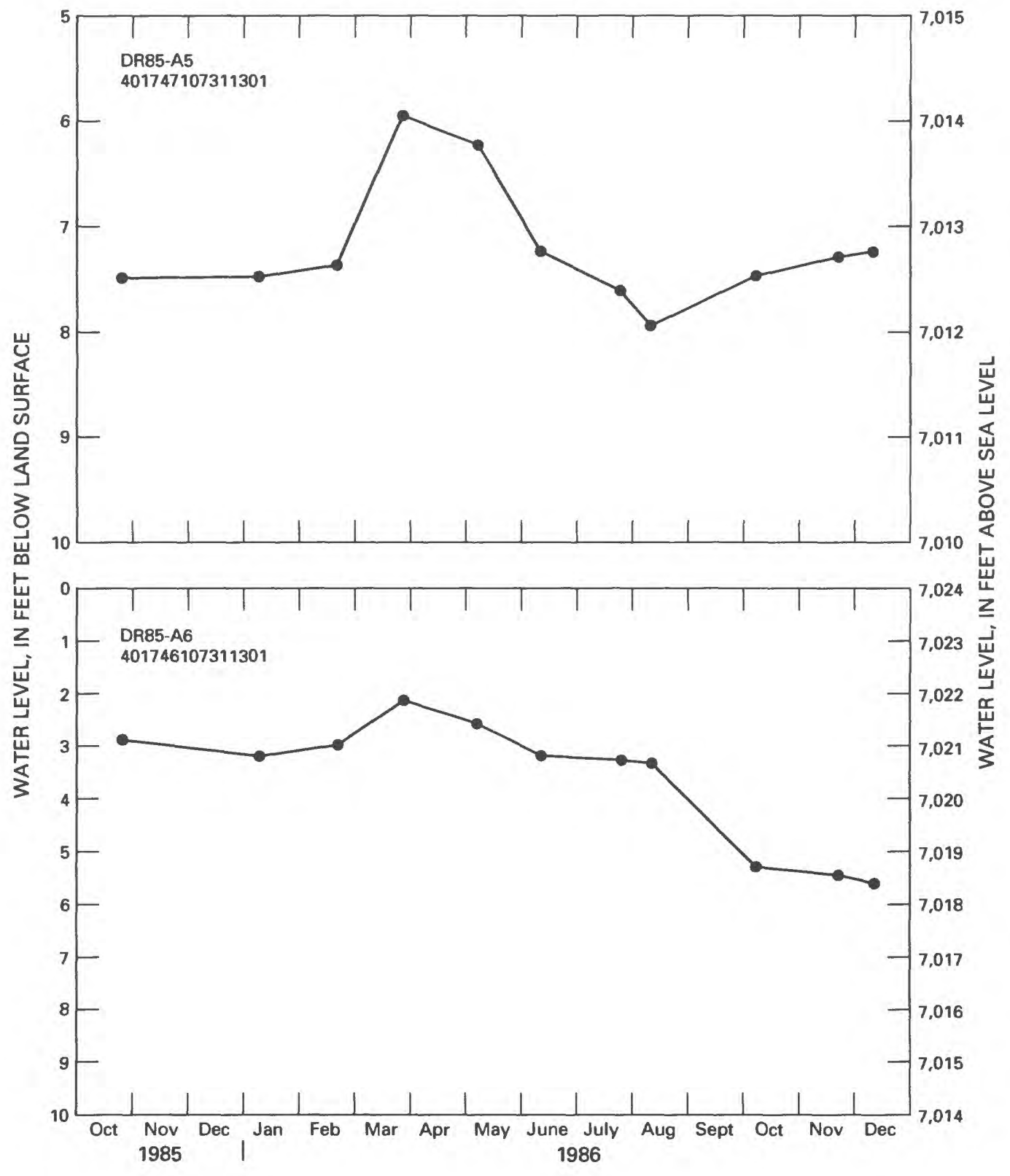

Figure 36C.--Water-level hydrographs for wells completed in valley-fill aquifers--Continued. 


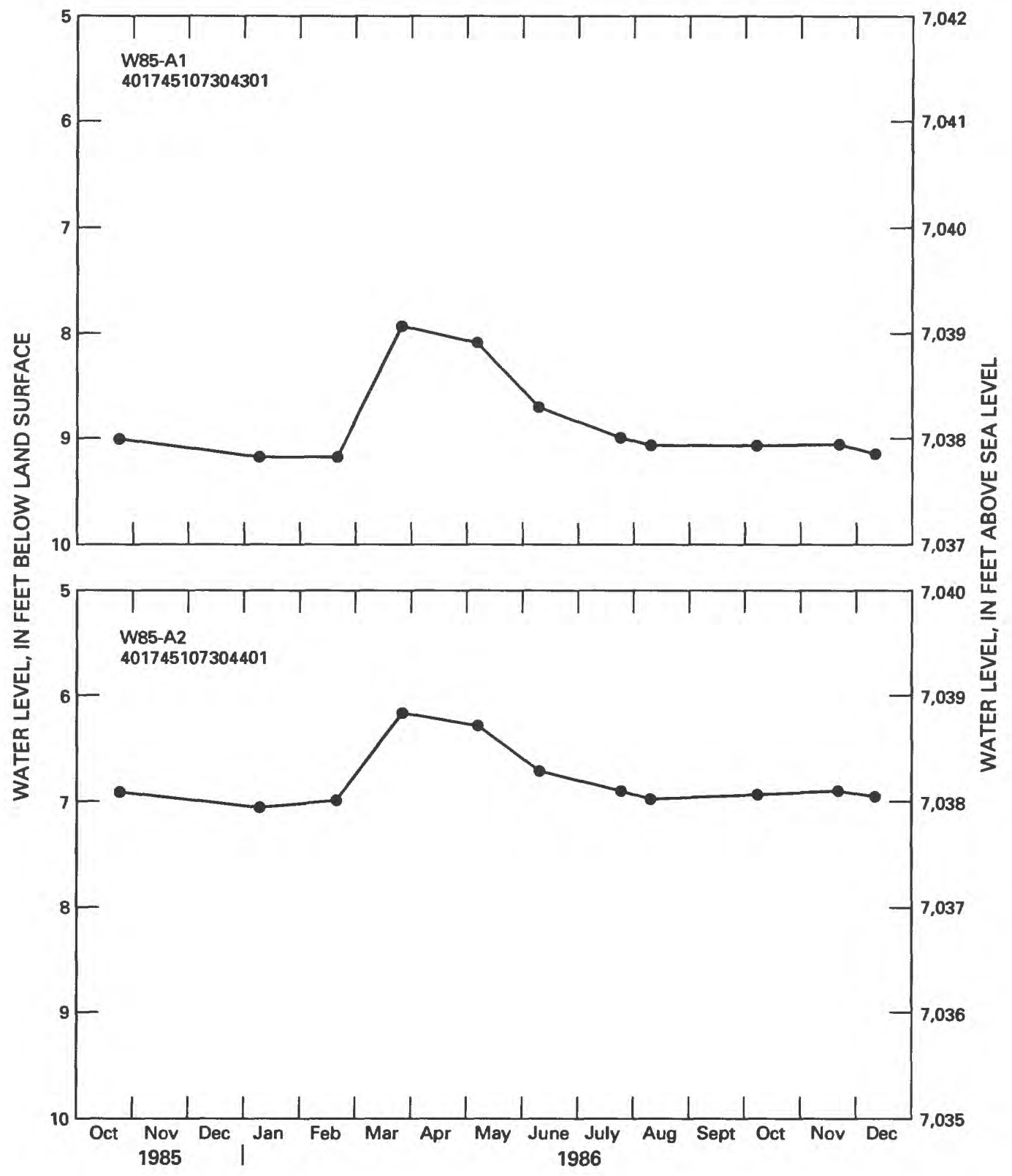

Figure 36D.--Water-level hydrographs for wells completed in valley-fill aquifers--Continued. 


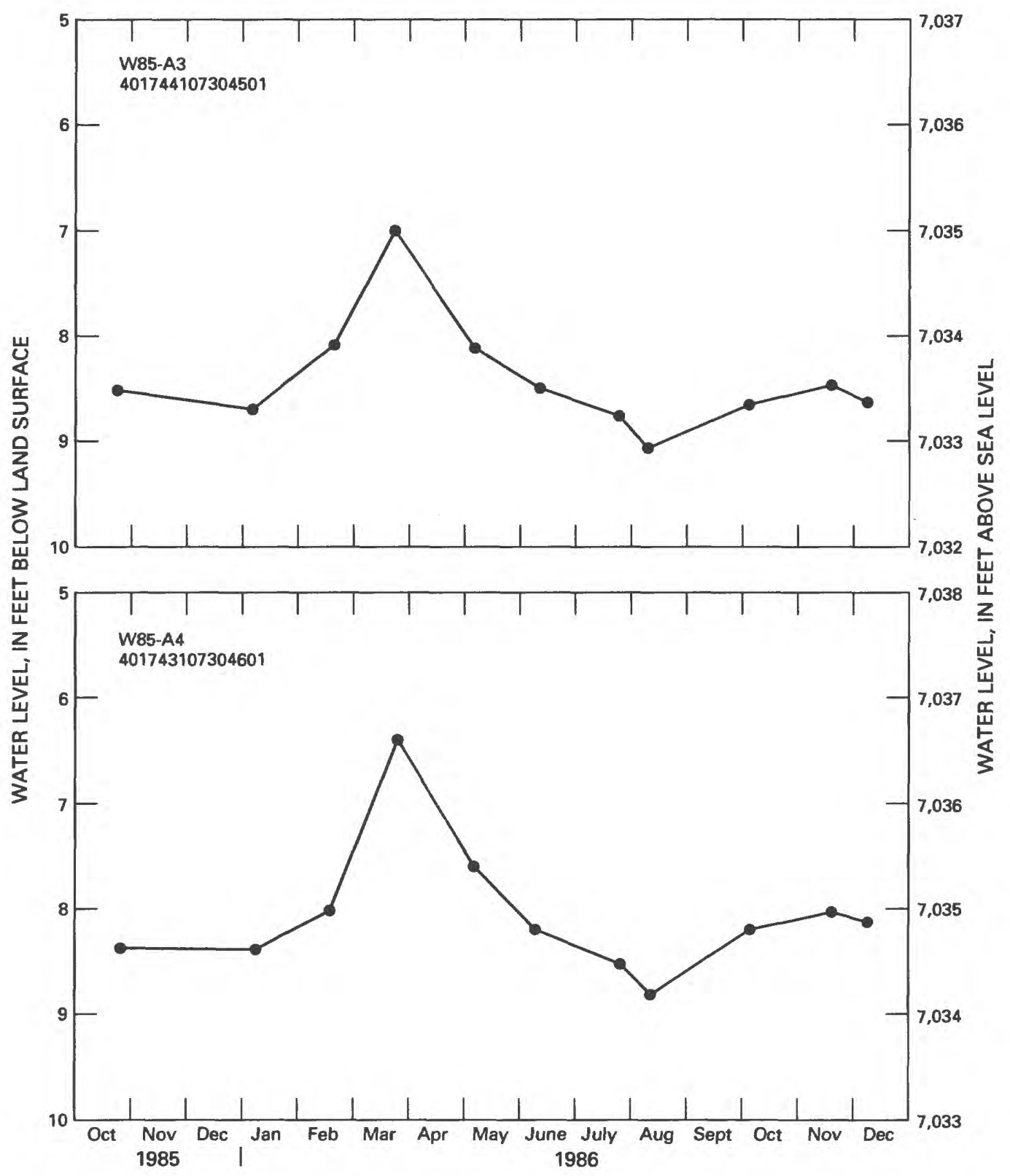

Figure 36E.--Water-level hydrographs for wells completed in valley-fill aquifers--Continued. 


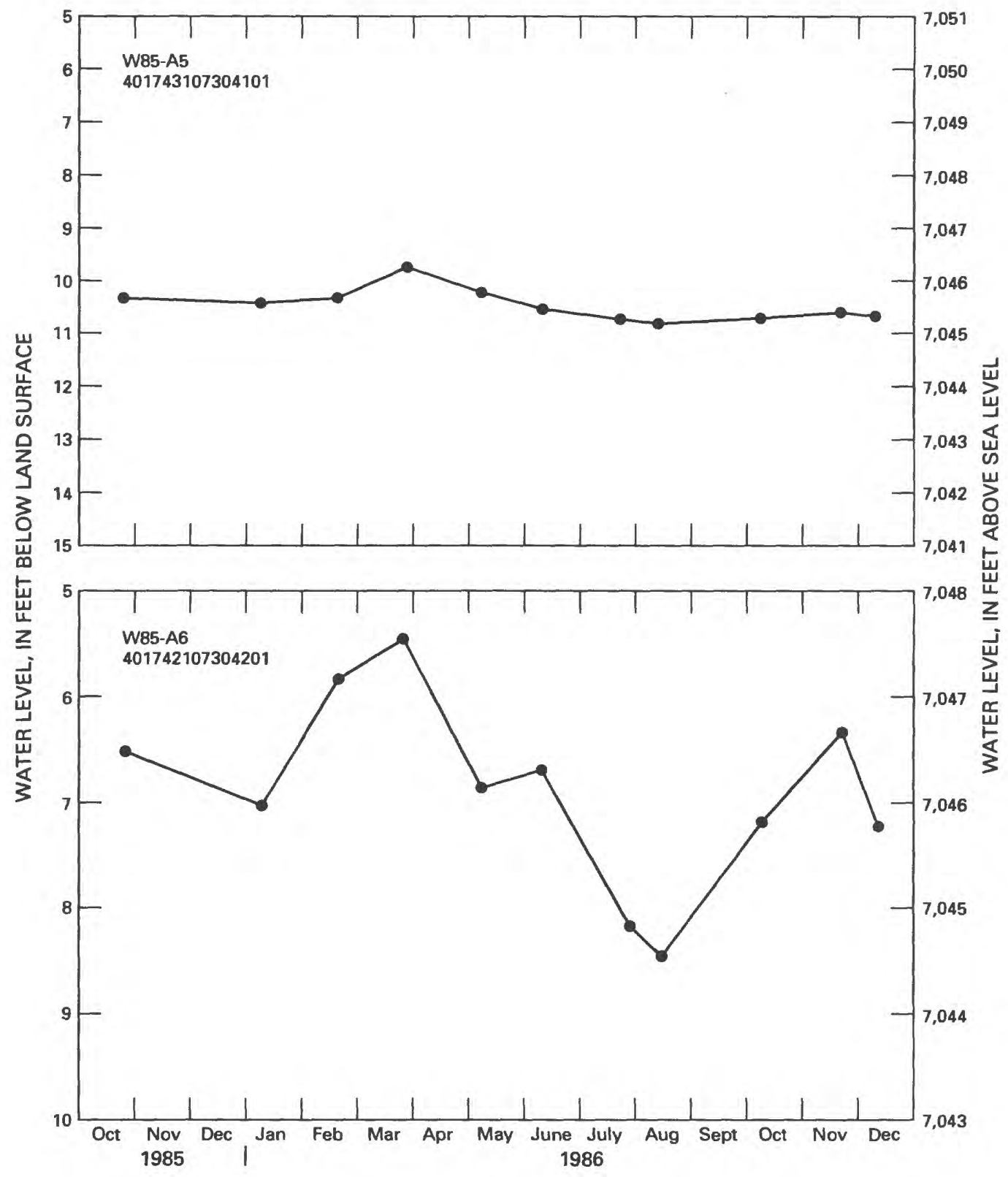

Figure 36F.--Water-level hydrographs for wells completed in valley-fill aquifers--Continued. 


\section{Analyses of Aquifer Tests}

Site HS85-34

An aquifer test was done at this site during July 27 to 28,1986 , by pumping well HS85-34c4 at about $0.64 \mathrm{gal} / \mathrm{min}$ for 1,000 minutes while monitoring water levels in the pumping well and in observation wells HS85-34-1, HS85-34-2, and HS85-34c1. A well-completion diagram and generalized geologic $\log$ for the wells at site HS85-34 are shown in figure 32 . The relation between drawdown of water levels in wells HS85-34c4, HS85-34-1, and HS85-34-2 and time since pumping started is shown in figure 37 . Well HS85-34c4, the

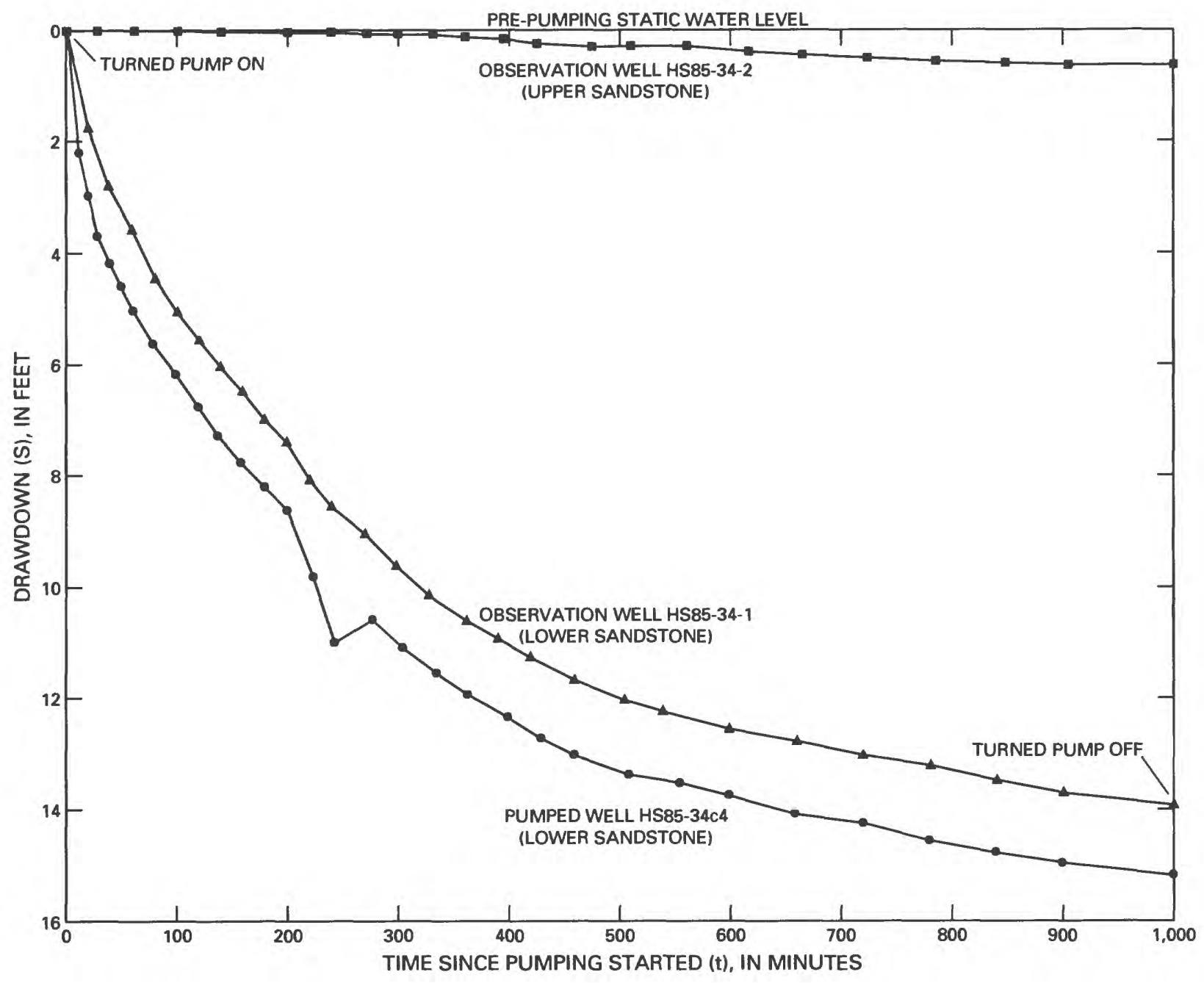

Figure 37.--Water-level changes in wells during test pumping of we11 HS85-34c4, July 27 to 28, 1986. 
pumping well, is screened in a lower sandstone unit of the upper part of the Williams Fork Formation. Observation well HS85-34-1 also is completed in the lower sandstone; observation well HS85-34-2 is completed in an upper sandstone of the upper part of the Williams Fork Formation (fig. 32). There was no change in water level in well HS85-34c1 during the duration of this test pumping. This well probably is completed in a locally fractured zone that is not hydraulically connected to either of these sandstone aquifers. The relation between pumping rate and time since pumping started is shown in figure 38 .

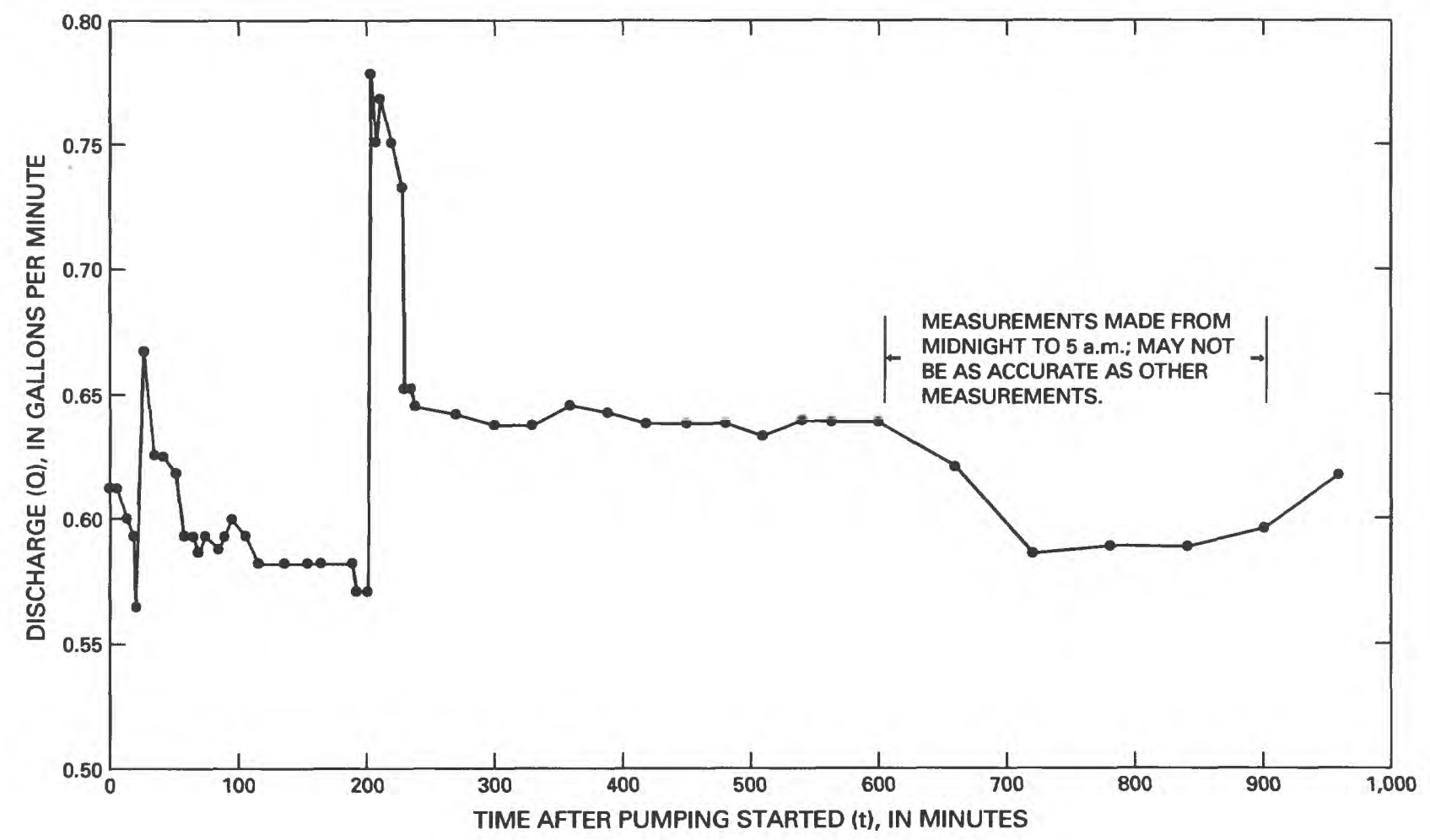

Figure 38.--Fluctuations in pumping rate during test pumping of well HS85-34c4, July 27 to $28,1986$. 
Hydraulic coefficients for the lower sandstone unit in this area were calculated using the relation between the logarithm of drawdown and time for observation well HS85-34-1 (fig. 39), which is located $26.8 \mathrm{ft}$ from the pumped well. The nonequilibrium $\log -\log$ curve matching technique of Papadopulos and Cooper (1967) were used with figure 8.3 of Reed (1980) to analyze the data. The effect of wellbore storage is significant in the pumped well until time exceeds about 350 minutes. This implies that only the last part of the drawdown curve is usable for determining transmissivity and storage coefficient. Reed's value of rho was calculated to be about 80 , and the data were matched to a curve for a rho of 80 on figure 8.3 of Reed (1980). Transmissivity calculated from this curve match was about $4 \mathrm{ft}^{2} / \mathrm{d}$; storage coefficient was calculated to be about $5 \times 10^{-5}$. Because only the later drawdown data could be used to match the curve, the resulting transmissivity and storage coefficient values are imprecise. The pumped well. and observation well are both completed in the same fractured sandstone, which is about $5 \mathrm{ft}$ thick. Using a saturated thickness of $5 \mathrm{ft}$, hydraulic conductivity was estimated to be about $0.8 \mathrm{ft} / \mathrm{d}$. The effect of leakage from the overlying sandstone can be seen from figure 37 , which shows that observation well HS85-34-2 began to undergo noticable drawdown after about 200 to 300 minutes of pumping at well HS85-34c4. This drawdown indicates that the bed of shale and unfractured coal that separates the upper sandstone from the lower sandstone is a leaky confining unit, through which water can be transmitted when the lower sandstone is stressed.

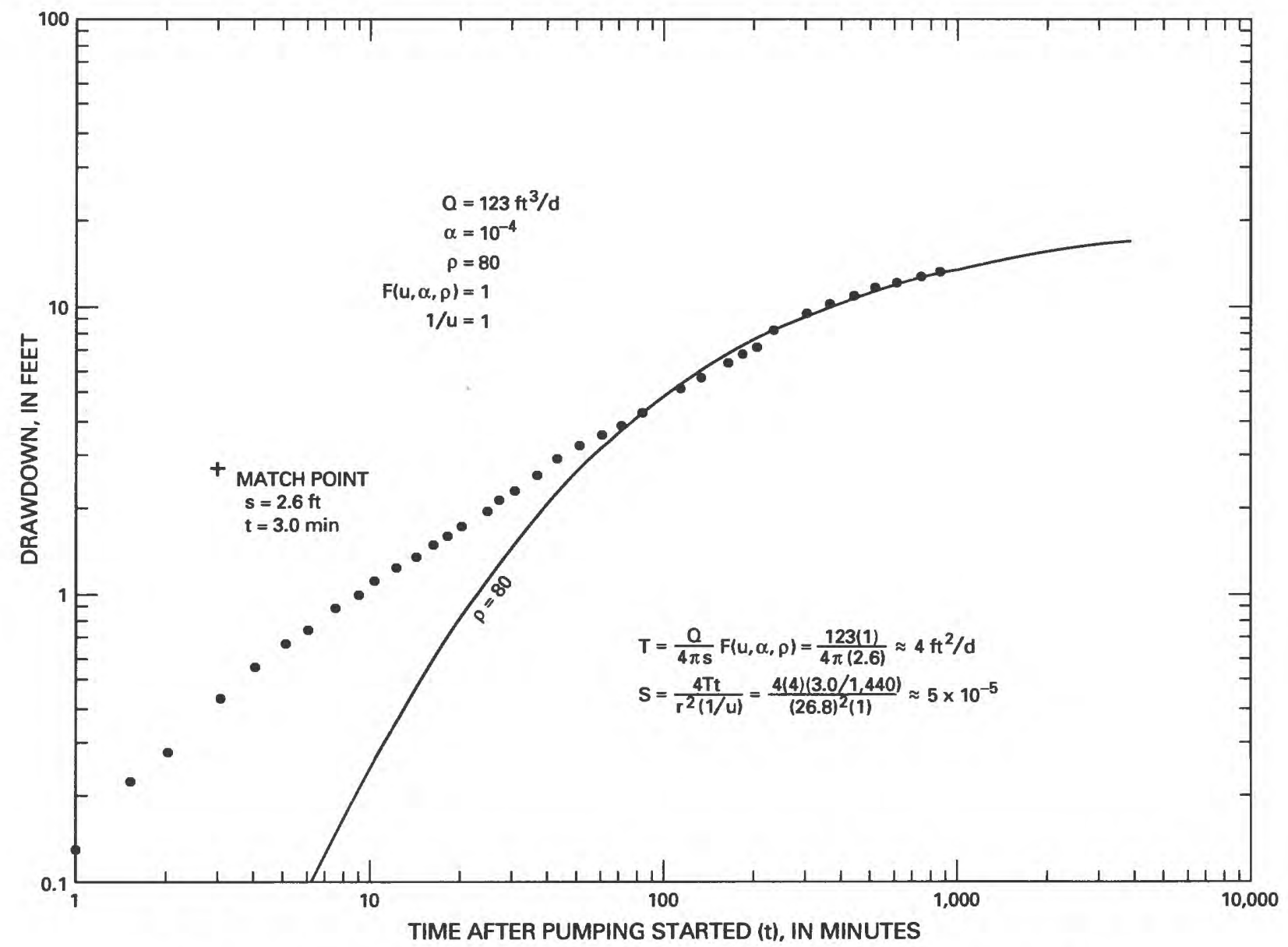

Figure 39.--Results of aquifer test using observation well HS85-34-1, July 27 to 28, 1986. 
Well HS85-20A2 is a flowing artesian well that was shut in by U.S. Geological Survey personnel soon after the well was completed. This well was completed in the upper coal aquifer and was used as an observation well to monitor aquifer hydraulic head. The well completion and generalized geology at this site are shown in figure 30 .

An aquifer test was done using this well during July 23 to August 9, 1986, by opening the well head, allowing the well to flow, and monitoring discharge from the well and aquifer pressure in the well. No observation wells exist nearby in the same aquifer for monitoring purposes; however, water-level changes were monitored in well HS85-20-2, located $47.5 \mathrm{ft}$ away, which was completed in the Trout Creek aquifer. During the 17 days that well HS85-20A2 was allowed to flow, the water level in well HS85-20-2 did not change, which indicates that the Yampa bed or other beds in the lower coal aquifer act as confining units between the upper coal aquifer and the Trout Creek aquifer.

Aquifer pressure in the flowing well stabilized after 420 minutes (fig 40). Transmissivity then was calculated to be about $9 \mathrm{ft}^{2} / \mathrm{d}$ by the method of Jacob and Lohman (1952) for nonsteady flow to a well of constant

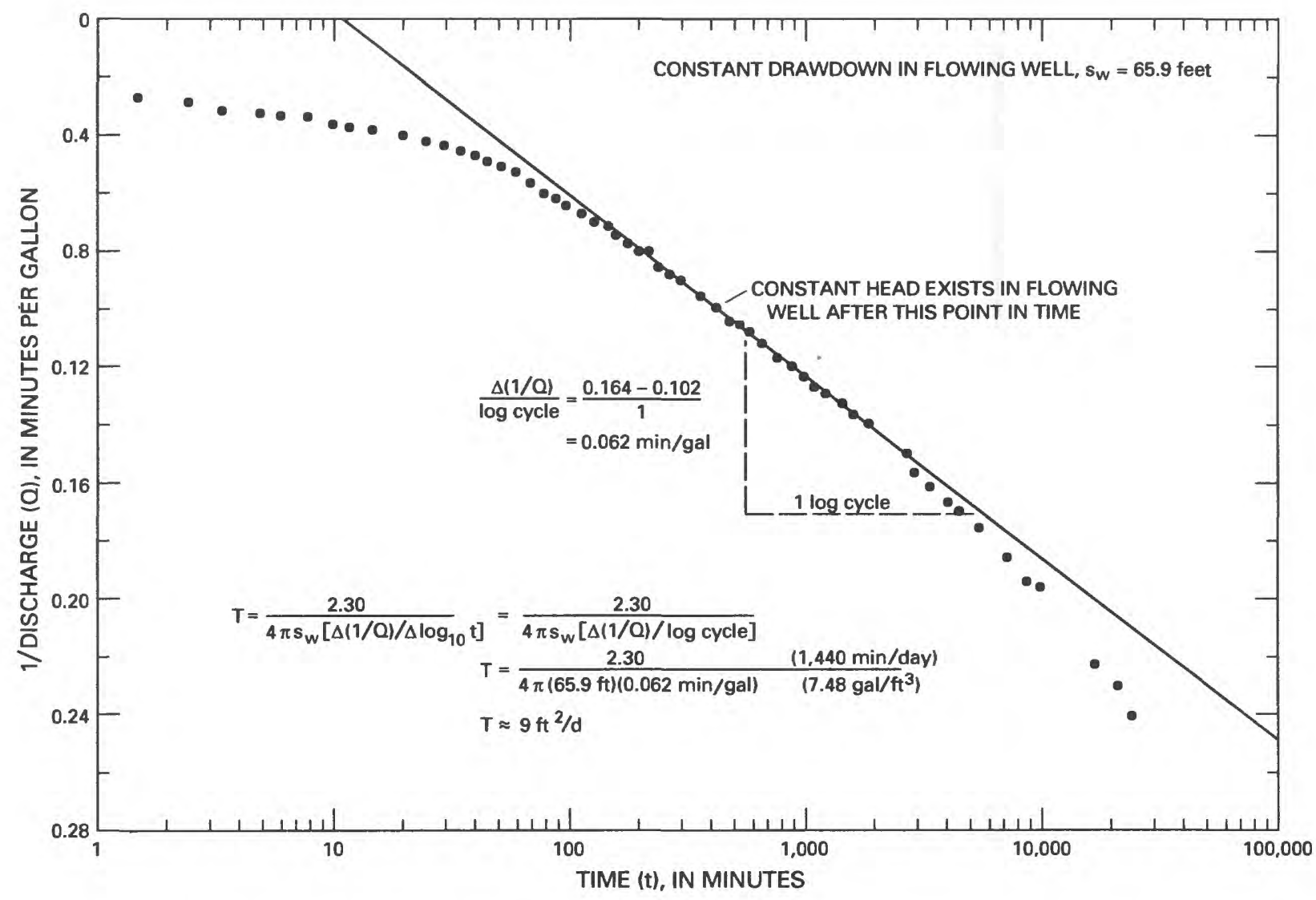

Figure 40.--Results of flowing-well aquifer test using well HS85-20A2, July 23 to August 9, 1986. 
drawdown. The reason for departure of discharge, $Q$, (actually 1/Q) from straight-1ine conditions after about 2,700 minutes is uncertain, but may be due to expansion of the drawdown cone to an impermeable boundary, a reduction in well efficiency, or a decrease in pressure in the aquifer other than that caused by the aquifer test. Storage coefficient was not calculated from this test because the needed effective radius of the flowing well was not known accurately due to the effect of the gravel pack, well development, and borehole caving in the screened interval.

\section{Site HS85-17}

An aquifer test was done at this site during August 12 to 13, 1986, by pumping well HS85-17-4 at about $0.8 \mathrm{gal} / \mathrm{min}$ for 1,000 minutes while monitoring water levels in the pumped well and in three observation wells. Well HS85-17-4, the pumped well, is completed in the lower coal aquifer. Observation well HS85-17c1S is completed in the upper coal aquifer; well HS85-17c1M is completed in the lower coal aquifer; and well HS85-17c1D is completed in the Trout Creek aquifer, as shown in figure 29. The relation between waterlevel drawdown in all four of these wells and time after pumping started is shown in figure 41. The relation between pumping rate and time after pumping

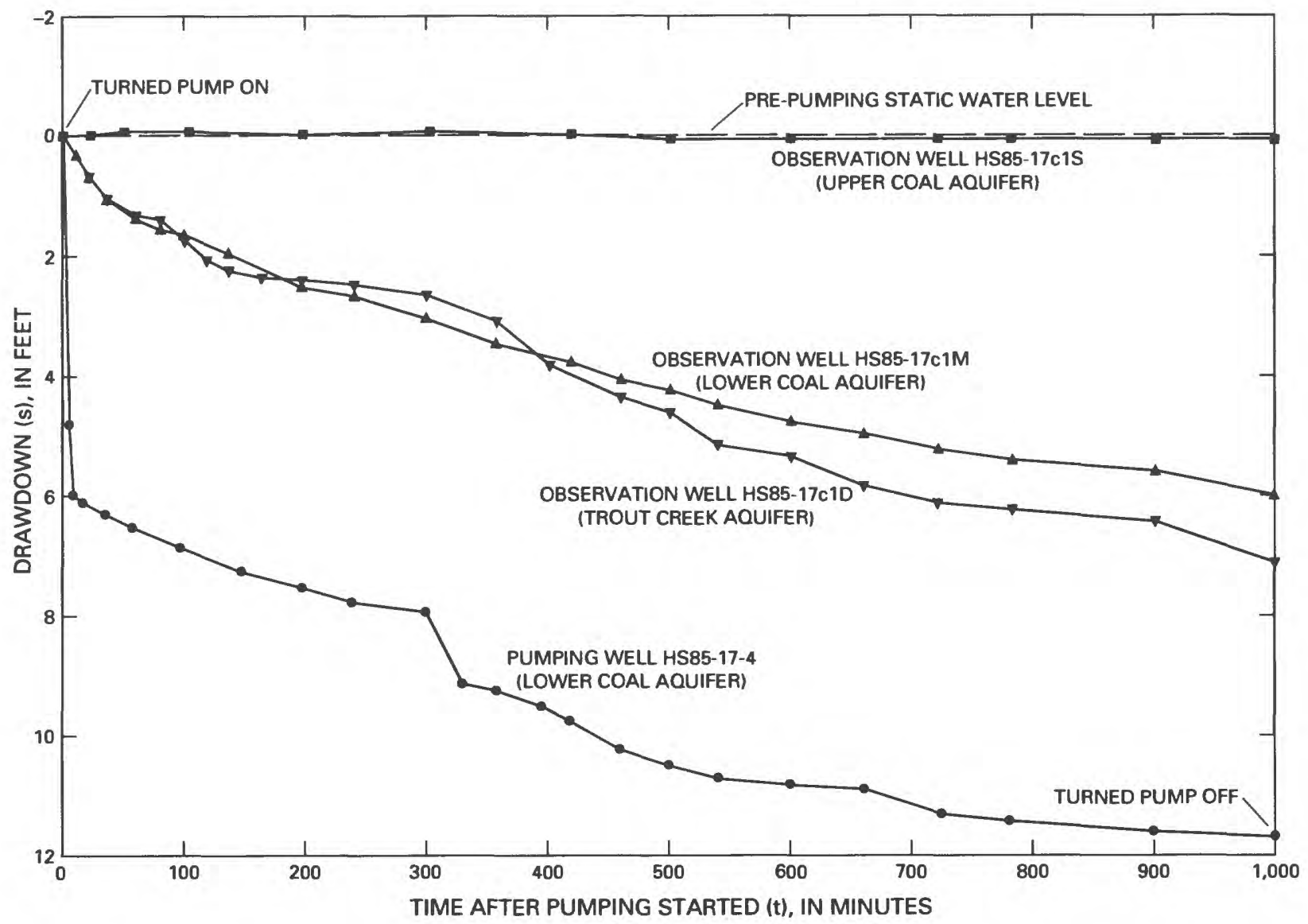

Figure 41.--Water-level changes in wells during test pumping of well HS85-17-4, August 12 to 13, 1986. 
started is shown in figure 42. As a result of pumping, drawdown in observation well HS85-17c1M, which was completed in the same aquifer as the pumping well, was about $6 \mathrm{ft}$ (fig. 41). Drawdown in the pumped well was about $12 \mathrm{ft}$. In addition, observation well HS85-17c1D, which was completed in the Trout Creek aquifer, had about $7 \mathrm{ft}$ of drawdown in response to the test pumping. However, negligible drawdown occurred in observation well HS85-17c1S for the duration of the test. These results indicate that the Yampa bed was an effective confining unit during the induced stress on the underlying aquifer. However, at this site, the confining bed between the lower coal aquifer and the Trout Creek aquifer is permeable enough to allow leakage of water between the Trout Creek aquifer and the lower coal aquifer. This investigation has not documented the lateral extent of the hydraulic connection between the lower coal aquifer and the Trout Creek aquifer that was observed at this site. The fluctuations in pumping rate indicated in figure 42 precluded precise interpretation of aquifer-test results. However, a transmissivity of about $7 \mathrm{ft}^{2} / \mathrm{d}$ and a hydraulic conductivity of about $0.6 \mathrm{ft} / \mathrm{d}$ may be reasonable estimates of these aquifer characteristics at site HS85-17.

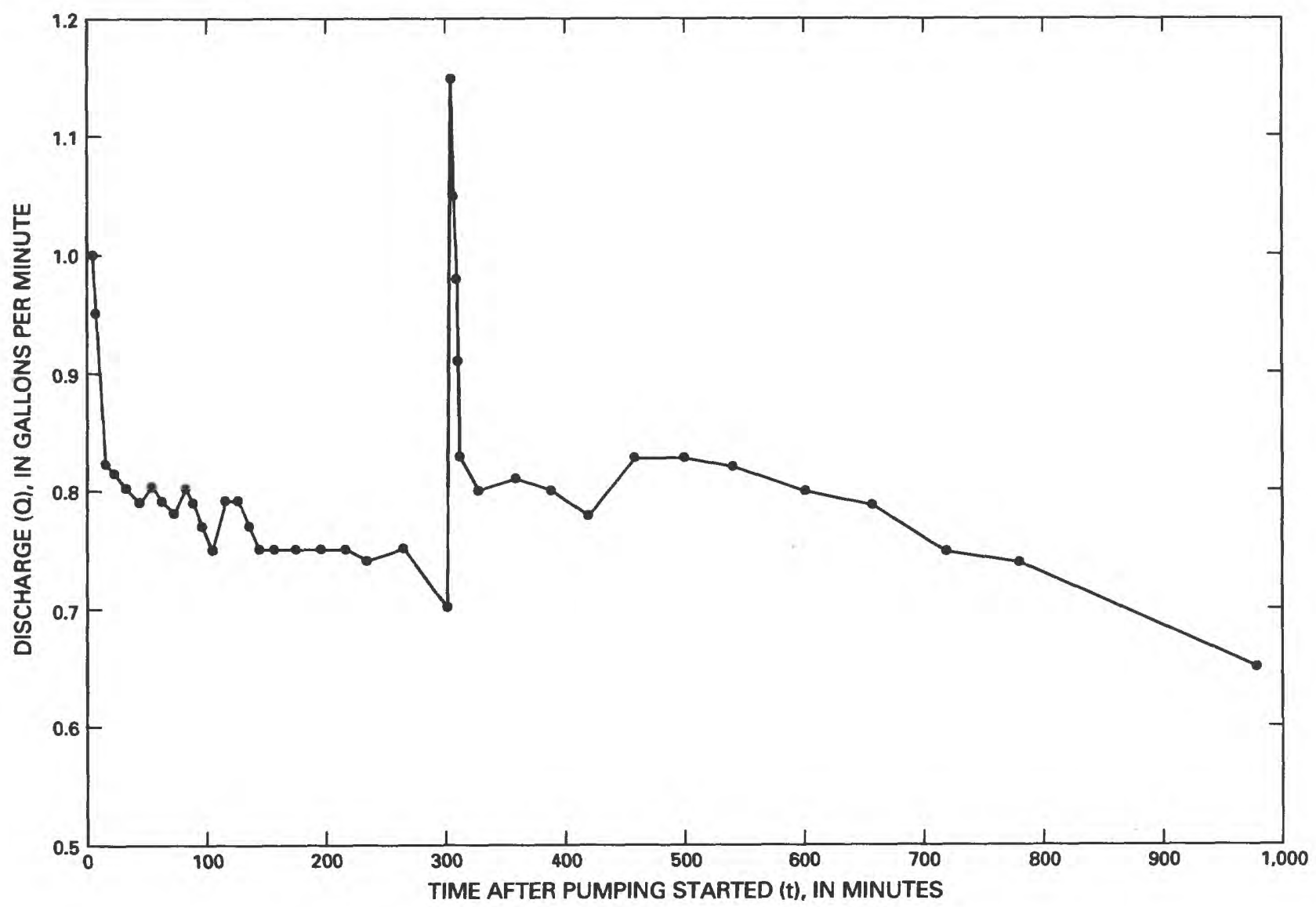

Figure 42.--Fluctuations in pumping rate during test pumping of well HS85-17-4, August 12 to 13, 1986. 
An aquifer test based on slug-test techniques was done in well HS85-20-2 on December 12, 1986. A cylindrical weight was lowered into the well and completely submerged beneath the water surface in the well as quickly as possible, to simulate an instantaneous injection of water. Then, the build-up and subsequent decline in water levels in the well were monitored with time since the injection of this "slug." The initial build-up of head in the well $\left(H_{0}\right)$ is equal to the volume of the slug divided by the cross-sectional area inside the casing in the interval over which the water level fluctuated. For this test, $H_{0}=11.54 \mathrm{ft}$. About 1 minute after injection of the slug, the water level in this well was about $10 \mathrm{ft}$ above the pre-injection static water level and was declining. Water levels in the well were monitored for 400 minutes ( 6 hours and 40 minutes); after that time, the water level in the well was $0.12 \mathrm{ft}$ above the pre-injection static water level.

Well HS85-20-2 was completed in the Trout Creek aquifer (see fig. 29 for well completion and generalized geology at this site). As shown in figure 29, this well was perforated through about $20 \mathrm{ft}$ of the Trout Creek Sandstone, which in this area is about 60 to $100 \mathrm{ft}$ thick. The data collected during the slug test were analyzed using the method of Cooper and others (1967) (fig. 43); transmissivity of the Trout Creek aquifer was calculated to be about $0.5 \mathrm{ft}^{2} / \mathrm{d}$. Assuming a saturated thickness of $100 \mathrm{ft}$, hydraulic conductivity is about $0.005 \mathrm{ft} / \mathrm{d}$. The departure of the data from the type curve for time less than 800 seconds may be due to effects of partial penetration of the aquifer by the well. Soon after the injection of the slug, the cone of impression around the well probably is affected only by that part of the aquifer over which the well is perforated. However, because the Trout Creek Sandstone is a relatively uniform, homogeneous beach sandstone (quartz arenite), it probably is little stratified. After sufficient time, the hydraulic stress on the aquifer caused by the injection of the slug expands through the entire thickness of the aquifer and the effects of partial penetration become insignificant (E.P. Weeks, U.S. Geological Survey, oral commun., 1986). Storage coefficient was not calculated from this test due to lack of knowledge about the effective radius of the well. 


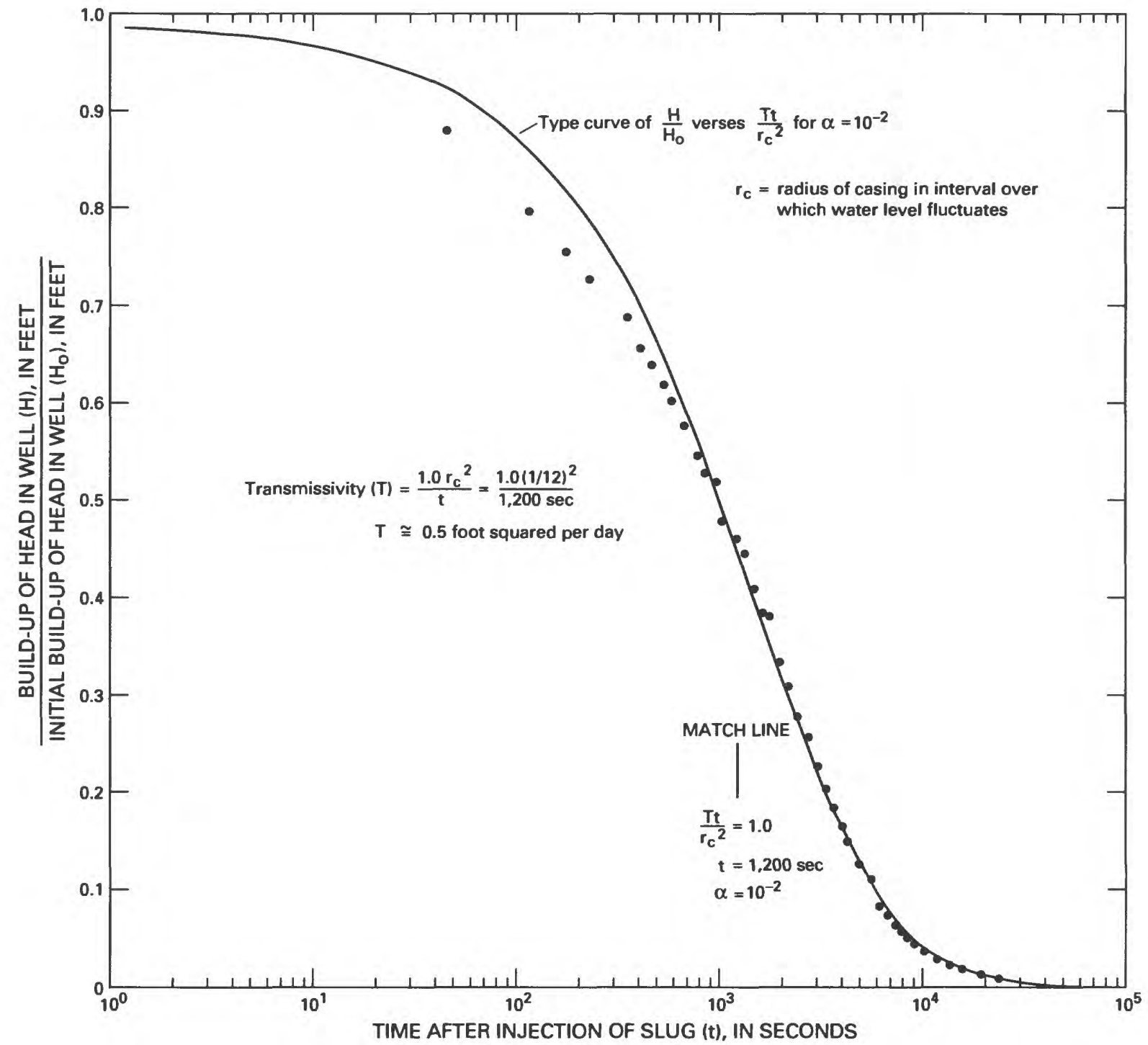

Figure 43.--Results of slug test using well HS85-20-2, December 12, 1986. 
Water-Quality Data 
Table 5.--Water-quality data for bedrock wells

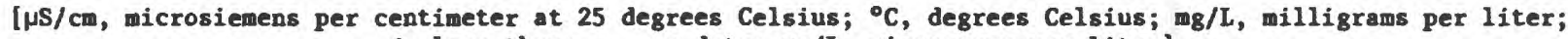
$<$, less than; --, no data; $\mu g / L$, micrograms per liter]

\begin{tabular}{|c|c|c|c|c|c|c|c|c|c|c|c|}
\hline $\begin{array}{l}\text { Station } \\
\text { name }\end{array}$ & Station number & $\begin{array}{c}\text { Date } \\
\text { of } \\
\text { sample }\end{array}$ & $\begin{array}{c}\text { Time } \\
\text { of } \\
\text { sample }\end{array}$ & $\begin{array}{l}\text { Spe- } \\
\text { cific } \\
\text { con- } \\
\text { duct- } \\
\text { ance } \\
(\mu S / c m)\end{array}$ & $\begin{array}{c}\text { pH } \\
\text { (stand- } \\
\text { ard } \\
\text { units) }\end{array}$ & $\begin{array}{l}\text { Temper- } \\
\text { ature, } \\
\text { air } \\
\left({ }^{\circ} \mathrm{C}\right)\end{array}$ & $\begin{array}{l}\text { Temper- } \\
\text { ature, } \\
\text { water } \\
\left({ }^{\circ} \mathrm{C}\right)\end{array}$ & $\begin{array}{l}\text { Hard- } \\
\text { ness } \\
(\mathrm{mg} / \mathrm{I} \\
\text { as } \\
\left.\mathrm{CaCO}_{3}\right)\end{array}$ & $\begin{array}{l}\text { Hard- } \\
\text { ness, } \\
\text { noncar- } \\
\text { bonate } \\
(\text { mg/I as } \\
\left.\mathrm{CaCO}_{3}\right)\end{array}$ & $\begin{array}{l}\text { Cal- } \\
\text { cium, } \\
\text { dis- } \\
\text { solved } \\
(\mathrm{mg} / \mathrm{L} \\
\text { as } \mathrm{Ca})\end{array}$ & $\begin{array}{l}\text { Magne- } \\
\text { sium, } \\
\text { dis- } \\
\text { solved } \\
\text { (mg/L } \\
\text { as Mg) }\end{array}$ \\
\hline HS85-1-1D & 401532107280201 & $08-05-86$ & 1800 & 1,700 & 8.1 & 20.0 & 11.0 & 160 & 0 & 25 & 24 \\
\hline HS85-1-1M & 401532107280202 & $08-05-86$ & 1515 & 1,590 & 8.5 & 22.0 & 11.0 & 140 & 0 & 24 & 20 \\
\hline HS85-1-1S & 401532107280203 & $08-06-86$ & 0930 & 4,000 & 7.0 & 18.0 & 11.0 & 2,700 & 2,500 & 300 & 470 \\
\hline HS85-15ol & 401617107310002 & $08-08-86$ & 0900 & 900 & 8.0 & -- & 10.0 & 410 & 0 & 81 & 50 \\
\hline HS85-16-1 & 401551107312801 & $08-07-86$ & 1100 & 850 & 7.9 & 31.0 & 11.0 & 59 & 0 & 12 & 7.0 \\
\hline HS85-17c1D & 401600107314001 & $08-09-86$ & 1800 & 920 & 8.2 & 19.0 & 11.0 & 440 & 0 & 87 & 54 \\
\hline HS $85-17-4$ & 401600107314101 & $08-08-86$ & 1500 & 960 & 7.0 & 19.5 & 12.5 & 530 & 0 & 110 & 62 \\
\hline HS85-17c1S & 401600107314003 & $08-09-86$ & 1130 & 540 & 7.4 & 22.0 & 10.0 & 300 & 48 & 66 & 33 \\
\hline \multirow[t]{2}{*}{ HS85-20-2 } & 401630107310701 & $09-30-85$ & 1500 & 1,270 & 8.8 & -- & 8.0 & 50 & 0 & 14 & 3.4 \\
\hline & & $08-10-86$ & 1730 & 1,150 & 8.7 & 20.0 & 11.5 & 35 & 0 & 7.2 & 4.0 \\
\hline \multirow[t]{2}{*}{ HS85-20A2 } & 401630107310601 & $09-27-85$ & 1000 & 1,150 & 8.2 & -- & 9.0 & 34 & 0 & 6.6 & 4.3 \\
\hline & & $07-23-86$ & 1230 & 1,380 & 8.4 & 18.0 & 8.5 & 10 & 0 & 2.6 & 0.9 \\
\hline HS 85-22c2 & 401625107313101 & $08-10-86$ & 1100 & 960 & 7.9 & 26.0 & 8.0 & 470 & 0 & 110 & 48 \\
\hline HS85-22cl & 401625107313102 & $08-10-86$ & 1230 & 1,550 & 7.6 & 22.0 & 9.5 & 220 & 0 & 51 & 23 \\
\hline HS85-34c4 & 401748107333601 & $07-27-86$ & 1445 & 810 & 6.5 & 28.0 & 16.0 & 440 & 270 & 110 & 41 \\
\hline HS $85-34-2$ & 401747107333602 & $07-29-86$ & 1800 & 620 & 8.0 & 24.0 & 9.0 & 340 & 91 & 82 & 33 \\
\hline HS $85-35 c 4$ & 401745107341301 & $07-30-86$ & 1300 & 750 & 6.6 & 25.0 & 10.0 & 420 & 84 & 110 & 35 \\
\hline HS85-35c1 & 401745107341302 & $07-29-86$ & 1130 & 1,950 & 7.8 & 27.5 & 8.5 & 1,100 & 660 & 240 & 120 \\
\hline HS85-38c1 & 401735107344902 & $07-27-86$ & 1130 & 540 & 7.5 & 21.0 & 9.0 & 290 & 20 & 71 & 28 \\
\hline HS85-24c & 401646107314601 & $09-18-85$ & 1105 & 1,110 & 7.6 & -- & 8.5 & 300 & 0 & 61 & 36 \\
\hline HSW1 & 401726107312301 & $08-12-86$ & 0900 & 1,100 & 7.6 & 20.0 & 9.0 & 290 & 0 & 58 & 34 \\
\hline HSW2 & 401726107312302 & $08-12-86$ & 1000 & 1,050 & 7.5 & 20.0 & 8.5 & 350 & 0 & 73 & 40 \\
\hline $\begin{array}{l}\text { Station } \\
\text { name }\end{array}$ & Station number & $\begin{array}{c}\text { Date } \\
\text { of } \\
\text { sample }\end{array}$ & $\begin{array}{l}\text { Sodium, } \\
\text { dis- } \\
\text { solved } \\
\text { (mg/L } \\
\text { as } \mathrm{Na} \text { ) }\end{array}$ & $\begin{array}{l}\text { Per- } \\
\text { cent } \\
\text { sodium }\end{array}$ & $\begin{array}{c}\text { Sodium } \\
\text { ad- } \\
\text { sorp- } \\
\text { tion } \\
\text { ratio }\end{array}$ & $\begin{array}{l}\text { Potas- } \\
\text { ium, } \\
\text { dis- } \\
\text { solved } \\
(\text { mg/L } \\
\text { as K) }\end{array}$ & $\begin{array}{c}\text { Alka- } \\
\text { linity, } \\
\text { lab } \\
(\mathrm{mg} / \mathrm{L} \\
\mathrm{as} \\
\mathrm{CaCO}_{3} \text { ) }\end{array}$ & $\begin{array}{l}\text { Sul- } \\
\text { fate, } \\
\text { dis- } \\
\text { solved } \\
\left(\mathrm{mg}_{\mathrm{g}} / \mathrm{L}\right. \\
\left.\text { as } \mathrm{SO}_{4}\right)\end{array}$ & $\begin{array}{l}\text { Chlo- } \\
\text { ride, } \\
\text { dis-, } \\
\text { solved } \\
\text { (ng/L } \\
\text { as Cl) }\end{array}$ & $\begin{array}{l}\text { Fluo- } \\
\text { ride, } \\
\text { dis- } \\
\text { solved } \\
\text { (mg/L } \\
\text { as F) }\end{array}$ & $\begin{array}{l}\text { Silica, } \\
\text { dis- } \\
\text { solved } \\
(\mathrm{mg} / \mathrm{L} \\
\text { as } \\
\left.\mathrm{SiO}_{2}\right)\end{array}$ \\
\hline HS85-1-1D & 401532107280201 & $08-05-86$ & 330 & 81 & 12 & 4.3 & 448 & 450 & 6.0 & 0.5 & 9.7 \\
\hline HS85-1-1M & 401532107280202 & $08-05-86$ & 300 & 81 & 11 & 5.6 & 461 & 380 & 6.1 & 0.5 & 7.9 \\
\hline HS85-1-1S & 401532107280203 & $08-06-86$ & 130 & 9 & 1 & 14 & 181 & 2,300 & 20 & 0.7 & 12 \\
\hline HS85-15c1 & 401617107310002 & $08-08-86$ & 54 & 22 & 1 & 7.6 & 457 & 97 & 6.3 & 0.5 & 15 \\
\hline HS85-16-1 & 401551107312801 & $08-07-86$ & 180 & 86 & 10 & 3.7 & 365 & 96 & 4.4 & 0.3 & 17 \\
\hline $\mathrm{HS} 85-17 \mathrm{C} 1 \mathrm{D}$ & 401600107314001 & $08-09-86$ & 37 & 15 & 0.8 & 5.9 & 448 & 65 & 5.5 & 0.3 & 20 \\
\hline HS85-17-4 & 401600107314101 & $08-08-86$ & 19 & 7 & 0.4 & 6.8 & 554 & 27 & 5.5 & 0.3 & 24 \\
\hline HS85-17c1S & 401600107314003 & $08-09-86$ & 4.9 & 3 & 0.1 & 3.2 & 253 & 61 & 5.4 & 0.3 & 15 \\
\hline HS85-20-2 & 401630107310701 & $09-30-85$ & 280 & 89 & 18 & 20 & 588 & 29 & 41 & 1.9 & 6.4 \\
\hline & & $08-10-86$ & 270 & 93 & 21 & 7.2 & 630 & 26 & 15 & 1.6 & 9.4 \\
\hline HS85-20A2 & 401630107310601 & $09-27-85$ & 270 & 94 & 21 & 2.6 & 648 & 17 & 4.5 & 1.4 & 9.0 \\
\hline & & $07-23-86$ & 360 & 98 & 51 & 2.8 & 829 & 19 & 3.1 & 3.5 & 7.6 \\
\hline HS85-22c2 & 401625107313101 & $08-10-86$ & 48 & 18 & 1 & 5.2 & 487 & 96 & 4.1 & 0.2 & 21 \\
\hline HS85-22c1 & 401625107313102 & $08-10-86$ & 270 & 72 & 8 & 8.9 & 711 & 160 & 4.5 & 0.8 & 8.7 \\
\hline HS85-34c4 & 401748107333601 & $07-27-86$ & 8.0 & 4 & 0.2 & 3.7 & 179 & 250 & 3.3 & 0.2 & 20 \\
\hline HS $85-34-2$ & 401747107333602 & $07-29-86$ & 5.1 & 3 & 0.1 & 1.8 & 250 & 100 & 2.9 & 0.2 & 10 \\
\hline HS $85-35 \mathrm{c} 4$ & 401745107341301 & $07-30-86$ & 7.9 & 4 & 0.2 & 6.4 & 336 & 70 & 4.4 & 0.2 & 16 \\
\hline HS $85-35 \mathrm{cl}$ & 401745107341302 & $07-29-86$ & 30 & 6 & 0.4 & 5.8 & 440 & 810 & 7.7 & 0.2 & 12 \\
\hline HS $85-38 \mathrm{cl}$ & 401735107344902 & $07-27-86$ & 7.2 & 5 & 0.2 & 2.0 & 273 & 21 & 2.8 & 0.6 & 17 \\
\hline HS $85-24 c$ & 401646107314601 & $09-18-85$ & 160 & 53 & 4 & 4.9 & 557 & 74 & 3.1 & 0.9 & 14 \\
\hline HSW1 & 401726107312301 & $08-12-86$ & 180 & 57 & 5 & 4.4 & 561 & 87 & 3.1 & 2.1 & 11 \\
\hline HSW2 & 401726107312302 & $08-12-86$ & 130 & 45 & 3 & 4.5 & 492 & 100 & 3.7 & 1.6 & 12 \\
\hline
\end{tabular}


Table 5.--Water-quality data for bedrock wells--Continued

\begin{tabular}{|c|c|c|c|c|c|c|c|c|c|c|}
\hline $\begin{array}{l}\text { Station } \\
\text { name }\end{array}$ & Station nuaber & $\begin{array}{l}\text { Date } \\
\text { of } \\
\text { sample }\end{array}$ & $\begin{array}{l}\text { Solids, } \\
\text { sum of } \\
\text { constit- } \\
\text { uents, } \\
\text { dis- } \\
\text { solved } \\
\text { (mg/L) }\end{array}$ & $\begin{array}{l}\text { Nitro- } \\
\text { gen, } \\
\text { nitrite, } \\
\text { total } \\
\text { (mg/L } \\
\text { as } N \text { ) }\end{array}$ & $\begin{array}{l}\text { Nitro- } \\
\text { gen, } \\
\text { nitrite, } \\
\text { dis- } \\
\text { solved } \\
\text { (mg/L } \\
\text { as } N \text { ) }\end{array}$ & $\begin{array}{l}\text { Nitro- } \\
\text { gen, } \\
\mathrm{NO}_{2}+\mathrm{NO}_{3}, \\
\text { total } \\
(\mathrm{mg} / \mathrm{L} \\
\text { as } \mathrm{N})\end{array}$ & $\begin{array}{c}\text { Nitro- } \\
\text { gen, } \\
\mathrm{NO}_{2}+\mathrm{NO}_{3}, \\
\text { dis- } \\
\text { solved } \\
\text { (mg/L } \\
\text { as } \mathrm{N})\end{array}$ & $\begin{array}{l}\text { Nitro- } \\
\text { gen, } \\
\mathrm{NH}_{4}, \\
\text { total } \\
(\mathrm{mg} / \mathrm{L} \\
\text { as } N)\end{array}$ & $\begin{array}{l}\text { Nitro- } \\
\text { gen, } \\
\text { MH } \\
\text { dis- } \\
\text { solved } \\
\text { (mg/L } \\
\text { as N) }\end{array}$ & $\begin{array}{l}\text { Nitro- } \\
\text { gen, } \\
\mathrm{NH}_{4}^{+} \\
\text {organic } \\
\text { dissolved } \\
(\mathrm{mg} / \mathrm{L} \\
\text { as } N)\end{array}$ \\
\hline $\begin{array}{l}\text { HS 85-1-1D } \\
\text { HS85-1-1M } \\
\text { HS85-1-1S } \\
\text { HS85-15c1 } \\
\text { HS85-16-1 }\end{array}$ & $\begin{array}{l}401532107280201 \\
401532107280202 \\
401532107280203 \\
401617107310002 \\
401551107312801\end{array}$ & $\begin{array}{l}08-05-86 \\
08-05-86 \\
08-06-86 \\
08-08-86 \\
08-07-86\end{array}$ & $\begin{array}{r}1,100 \\
1,000 \\
3,400 \\
590 \\
540\end{array}$ & $\begin{array}{c}0.02 \\
- \\
- \\
-- \\
0.04\end{array}$ & $\begin{array}{l}\cdots \\
0.01 \\
0.02 \\
-.\end{array}$ & $\begin{array}{c}0.70 \\
-- \\
=- \\
0.50\end{array}$ & $\begin{array}{c}-. \\
43.0 \\
0.39 \\
-.\end{array}$ & $\begin{array}{c}0.32 \\
-- \\
=- \\
0.18\end{array}$ & $\begin{array}{c}-- \\
0.95 \\
-- \\
--\end{array}$ & $\begin{array}{r}-- \\
2.0 \\
<0.2 \\
--\end{array}$ \\
\hline $\begin{array}{l}\text { HS 85-17c1D } \\
\text { HS85-17-4 } \\
\text { HS85-17c1S } \\
\text { HS85-20-2 } \\
\text { HS85-20A2 }\end{array}$ & $\begin{array}{l}401600107314001 \\
401600107314101 \\
401600107314003 \\
401630107310701 \\
401630107310601\end{array}$ & $\begin{array}{l}08-09-86 \\
08-08-86 \\
08-09-86 \\
09-30-85 \\
08-10-86 \\
09-27-85 \\
07-23-86\end{array}$ & $\begin{array}{l}550 \\
590 \\
340 \\
750 \\
720 \\
710 \\
900\end{array}$ & $\begin{array}{c}0.02 \\
-- \\
<0.01 \\
-- \\
0.02 \\
-- \\
--\end{array}$ & $\begin{array}{c}-\overline{0} \\
<0.01 \\
-\overline{0.01} \\
-- \\
<0.01 \\
<0.01\end{array}$ & $\begin{array}{c}0.10 \\
-- \\
<0.10 \\
-- \\
<0.10 \\
-- \\
--\end{array}$ & $\begin{array}{c}<0.10 \\
<-- \\
<0.10 \\
-\overline{-} \\
<0.10 \\
<0.10\end{array}$ & $\begin{array}{c}1.50 \\
0.27 \\
0.28 \\
0.28 \\
=\end{array}$ & $\begin{array}{c}1.90 \\
0- \\
0.10 \\
0 . \\
0.15 \\
0.08\end{array}$ & $\begin{array}{l}-.- \\
2.0 \\
-- \\
0.5 \\
-.- \\
0.6 \\
0.6\end{array}$ \\
\hline $\begin{array}{l}\text { HS } 85-22 c 2 \\
\text { HS } 85-22 c 1 \\
\text { HS } 85-34 c 4 \\
\text { HS } 85-34-2 \\
\text { HS85-35c4 }\end{array}$ & $\begin{array}{l}401625107313101 \\
401625107313102 \\
401748107333601 \\
401747107333602 \\
401745107341301\end{array}$ & $\begin{array}{l}08-10-86 \\
08-10-86 \\
07-27-86 \\
07-29-86 \\
07-30-86\end{array}$ & $\begin{array}{l}630 \\
960 \\
550 \\
390 \\
460\end{array}$ & $\begin{array}{c}<0.01 \\
<0.01 \\
=- \\
-- \\
--\end{array}$ & $\begin{array}{l}<0.01 \\
<0.01 \\
<0.01 \\
<0.01\end{array}$ & $\begin{array}{c}<0.10 \\
<0.10 \\
\ldots \\
-- \\
--\end{array}$ & $\begin{array}{r}<0.10 \\
<0 \\
<0.10 \\
0.25 \\
<0.10\end{array}$ & $\begin{array}{l}1.10 \\
1.80 \\
-- \\
- \\
-\end{array}$ & $\begin{array}{l}1.10 \\
-.15 \\
0.15 \\
0.02 \\
1.30\end{array}$ & $\begin{array}{l}1.6 \\
-- \\
0.3 \\
1.1 \\
1.8\end{array}$ \\
\hline $\begin{array}{l}\text { HS85-35c1 } \\
\text { HS85-38c1 } \\
\text { HS85-24c } \\
\text { HSW1 } \\
\text { HSW2 }\end{array}$ & $\begin{array}{l}401745107341302 \\
401735107344902 \\
401646107314601 \\
401726107312301 \\
401726107312302\end{array}$ & $\begin{array}{l}07-29-86 \\
07-27-86 \\
09-18-85 \\
08-12-86 \\
08-12-86\end{array}$ & $\begin{array}{r}1,500 \\
310 \\
690 \\
770 \\
690\end{array}$ & $\begin{array}{c}-- \\
-- \\
<0.01 \\
<0.01\end{array}$ & $\begin{array}{c}<0.01 \\
<0.01 \\
<0.01 \\
\ldots- \\
-.\end{array}$ & $\begin{array}{c}-- \\
-- \\
<0.10 \\
<0.10\end{array}$ & $\begin{array}{l}0.10 \\
1.10 \\
0.16 \\
-- \\
--\end{array}$ & $\begin{array}{c}-- \\
-- \\
0.64 \\
0.62\end{array}$ & $\begin{array}{c}0.27 \\
0.08 \\
1.30 \\
-- \\
--\end{array}$ & $\begin{array}{l}0.8 \\
0.8 \\
1.4 \\
-. \\
--\end{array}$ \\
\hline $\begin{array}{l}\text { Station } \\
\text { name }\end{array}$ & Station number & $\begin{array}{c}\text { Date } \\
\text { of } \\
\text { sample }\end{array}$ & $\begin{array}{l}\text { Phos- } \\
\text { phorus, } \\
\text { dis- } \\
\text { solved } \\
\text { (mg/L } \\
\text { as } \mathrm{P} \text { ) }\end{array}$ & $\begin{array}{l}\text { Phos- } \\
\text { phorus, } \\
\text { ortho, } \\
\text { solved } \\
\text { (mg/L } \\
\text { as P) }\end{array}$ & $\begin{array}{c}\text { Phos- } \\
\text { phorus, } \\
\text { ortho, } \\
\text { dis- } \\
\text { solved } \\
\text { (mg/L } \\
\text { as P) }\end{array}$ & $\begin{array}{l}\text { Arsenic, } \\
\text { dis- } \\
\text { solved } \\
(\mu g / L \\
\text { as As) }\end{array}$ & $\begin{array}{l}\text { Barium, } \\
\text { dis- } \\
\text { solved } \\
(\mu g / L \\
\text { as } \mathrm{Ba})\end{array}$ & $\begin{array}{l}\text { Boron, } \\
\text { dis- } \\
\text { solved } \\
(\mu g / L \\
\text { as B) }\end{array}$ & $\begin{array}{l}\text { Cobalt, } \\
\text { dis- } \\
\text { solved } \\
(\mu g / L \\
\text { as Co })\end{array}$ & $\begin{array}{l}\text { Iron, } \\
\text { dis- } \\
\text { solved } \\
(\mu g / L \\
\text { as Fe) }\end{array}$ \\
\hline $\begin{array}{l}\text { HS85-1-1D } \\
\text { HS85-1-1M } \\
\text { HS } 85-1-1 S \\
\text { HS85-15c1 } \\
\text { HS85-16-1 }\end{array}$ & $\begin{array}{l}401532107280201 \\
401532107280202 \\
401532107280203 \\
401617107310002 \\
401551107312801\end{array}$ & $\begin{array}{l}08-05-86 \\
08-05-86 \\
08-06-86 \\
08-08-86 \\
08-07-86\end{array}$ & $\begin{array}{l}=- \\
-- \\
0.02 \\
0.03 \\
=-\end{array}$ & $\begin{array}{c}0.03 \\
=- \\
=- \\
0.06\end{array}$ & $\begin{array}{l}-- \\
0.02 \\
--\end{array}$ & $\begin{array}{r}<1 \\
1 \\
<1 \\
<1 \\
<1\end{array}$ & $\begin{array}{r}25 \\
50 \\
<100 \\
130 \\
100\end{array}$ & $\begin{array}{l}230 \\
270 \\
290 \\
210 \\
240\end{array}$ & $\begin{array}{r}<1 \\
<1 \\
2 \\
1 \\
<1\end{array}$ & $\begin{array}{l}80 \\
59 \\
40 \\
11 \\
25\end{array}$ \\
\hline $\begin{array}{l}\text { HS } 85-17 \text { c1D } \\
\text { HS } 85-17-4 \\
\text { HS } 85-17 c 1 S \\
\text { HS85-20-2 } \\
\text { HS85-20A2 }\end{array}$ & $\begin{array}{l}401600107314001 \\
401600107314101 \\
401600107314003 \\
401630107310701\end{array}$ & $\begin{array}{l}08-09-86 \\
08-08-86 \\
08-09-86 \\
09-30-85 \\
08-10-86 \\
09-27-85 \\
07-23-86\end{array}$ & $\begin{array}{c}-- \\
0.12 \\
-- \\
0.03 \\
-- \\
0.17 \\
0.10\end{array}$ & $\begin{array}{c}0.08 \\
-- \\
<0.01 \\
-- \\
0.12 \\
--\end{array}$ & $\begin{array}{c}-- \\
0.10 \\
-- \\
0.02 \\
=- \\
0.15 \\
0.11\end{array}$ & $\begin{array}{r}2 \\
<1 \\
<1 \\
2 \\
2 \\
18 \\
<1 \\
<1\end{array}$ & $\begin{array}{r}200 \\
460 \\
170 \\
38 \\
31 \\
120 \\
100\end{array}$ & $\begin{array}{r}530 \\
600 \\
40 \\
180 \\
220 \\
160 \\
180\end{array}$ & $\begin{array}{r}<1 \\
1 \\
<1 \\
<1 \\
<1 \\
<1 \\
<1\end{array}$ & $\begin{array}{r}3 \\
71 \\
7 \\
11 \\
8 \\
59 \\
42\end{array}$ \\
\hline $\begin{array}{l}\text { HS } 85-22 c 2 \\
\text { HS } 85-22 c 1 \\
\text { HS } 85-34 c 4 \\
\text { HS } 85-34-2 \\
\text { HS } 85-35 c 4\end{array}$ & $\begin{array}{l}401625107313101 \\
401625107313102 \\
401748107333601 \\
401747107333602 \\
401745107341301\end{array}$ & $\begin{array}{l}08-10-86 \\
08-10-86 \\
07-27-86 \\
07-29-86 \\
07-30-86\end{array}$ & $\begin{array}{c}0.04 \\
-. \\
0.01 \\
0.01 \\
<0.01\end{array}$ & $\begin{array}{c}0.05 \\
0.02 \\
-- \\
-- \\
--\end{array}$ & $\begin{array}{l}0.04 \\
-. \\
0.01 \\
<0.01 \\
<0.01\end{array}$ & $\begin{array}{r}<1 \\
<1 \\
<1 \\
<1 \\
6\end{array}$ & $\begin{array}{r}140 \\
82 \\
37 \\
61 \\
690\end{array}$ & $\begin{array}{r}270 \\
260 \\
270 \\
20 \\
130\end{array}$ & $\begin{array}{r}1 \\
<1 \\
<1 \\
1 \\
1\end{array}$ & $\begin{array}{r}5 \\
13 \\
2,100 \\
21 \\
1,500\end{array}$ \\
\hline $\begin{array}{l}\text { HS85-35c1 } \\
\text { HS85-38c1 } \\
\text { HS85-24c } \\
\text { HSW1 } \\
\text { HSW2 }\end{array}$ & $\begin{array}{l}401745107341302 \\
401735107344902 \\
401646107314601 \\
401726107312301 \\
401726107312302\end{array}$ & $\begin{array}{l}07-29-86 \\
07-27-86 \\
09-18-85 \\
08-12-86 \\
08-12-86\end{array}$ & $\begin{array}{l}0.01 \\
0.01 \\
0.04 \\
-. \\
.-\end{array}$ & $\begin{array}{r}-- \\
-- \\
\overline{-} \\
0.04 \\
<0.01\end{array}$ & $\begin{array}{c}<0.01 \\
<0.01 \\
0.02 \\
-. \\
--\end{array}$ & $\begin{array}{l}4 \\
<1 \\
<1 \\
<1 \\
<1\end{array}$ & $\begin{array}{l}100 \\
120 \\
250 \\
400 \\
250\end{array}$ & $\begin{array}{r}80 \\
30 \\
180 \\
160 \\
140\end{array}$ & $\begin{array}{r}2 \\
<1 \\
<1 \\
<1 \\
2\end{array}$ & $\begin{array}{l}270 \\
460 \\
130 \\
110 \\
270\end{array}$ \\
\hline
\end{tabular}


Table 5.--Water-quality data for bedrock wells--Continued

\begin{tabular}{|c|c|c|c|c|c|c|c|c|c|c|c|}
\hline $\begin{array}{l}\text { Station } \\
\text { name }\end{array}$ & Station number & $\begin{array}{c}\text { Date } \\
\text { of } \\
\text { sample }\end{array}$ & $\begin{array}{l}\text { Lead, } \\
\text { dis- } \\
\text { solved } \\
\left(\mu_{g} / L\right. \\
\text { as } \mathrm{Pb})\end{array}$ & $\begin{array}{c}\text { Lithium, } \\
\text { dis- } \\
\text { solved } \\
(\mu \mathrm{g} / \mathrm{L} \\
\text { as } \mathrm{Li})\end{array}$ & $\begin{array}{l}\text { Manga- } \\
\text { nese, } \\
\text { dis- } \\
\text { solved } \\
\left(\mu_{g} / L\right. \\
\text { as } M n)\end{array}$ & $\begin{array}{c}\text { Molyb- } \\
\text { denum, } \\
\text { dis- } \\
\text { solved } \\
\left(\mu_{g} / L\right. \\
\text { as } \mathrm{Mo})\end{array}$ & $\begin{array}{l}\text { Nickel, } \\
\text { dis- } \\
\text { solved } \\
\left(\mu_{g} / L\right. \\
\text { as } \mathrm{Ni})\end{array}$ & $\begin{array}{l}\text { Sele- } \\
\text { nium, } \\
\text { dis- } \\
\text { solved } \\
(\mu \mathrm{g} / \mathrm{L} \\
\text { as } \mathrm{Se})\end{array}$ & $\begin{array}{l}\text { Stron- } \\
\text { tium, } \\
\text { dis- } \\
\text { solved } \\
\left(\mu_{g} / L\right. \\
\text { as } S r)\end{array}$ & $\begin{array}{l}\text { Vana- } \\
\text { dium, } \\
\text { dis- } \\
\text { solved } \\
(\mu g / L \\
\text { as V) }\end{array}$ & $\begin{array}{l}\text { Zinc, } \\
\text { dis- } \\
\text { solved } \\
(\mu g / L \\
\text { as } \mathrm{Zn})\end{array}$ \\
\hline HS85-1-1D & 401532107280201 & $08-05-86$ & $<5$ & 110 & 26 & $<1$ & 2 & $<1$ & 1,100 & 2 & 71 \\
\hline HS85-1-1M & 401532107280202 & $08-05-86$ & $<5$ & 110 & 22 & 1 & 5 & 2 & 960 & 6 & 17 \\
\hline HS85-1-1S & 401532107280203 & $08-06-86$ & $<5$ & 340 & 190 & 1 & 9 & 30 & 5,000 & 1 & 80 \\
\hline HS85-15c1 & 401617107310002 & $08-08-86$ & $<5$ & 59 & 80 & $<1$ & 2 & $<1$ & 930 & 2 & 120 \\
\hline HS85-16-1 & 401551107312801 & $08-07-86$ & $<5$ & 68 & 9 & $<1$ & 3 & $<1$ & 250 & 10 & 12 \\
\hline HS85-17clD & 401600107314001 & $08-09-86$ & $<5$ & 77 & 62 & 2 & 5 & $<1$ & 1,400 & 2 & 9 \\
\hline HS85-17-4 & 401600107314101 & $08-08-86$ & $<5$ & 74 & 120 & 1 & 1 & $<1$ & 1,800 & 1 & 26 \\
\hline HS $85-17 c 1 S$ & 401600107314003 & $08-09-86$ & $<5$ & 23 & 190 & $<1$ & 5 & $<1$ & 200 & 1 & 25 \\
\hline \multirow[t]{2}{*}{ HS85-20-2 } & 401630107310701 & $09-30-85$ & -- & 70 & 40 & 13 & 10 & -- & 450 & -- & 13 \\
\hline & & $08-10-86$ & $<5$ & 27 & 11 & 16 & 7 & $<1$ & 190 & 1 & 12 \\
\hline \multirow[t]{2}{*}{ HS85-20A2 } & 401630107310601 & $09-27-85$ & - & 39 & 6 & $<1$ & 16 & -- & 60 & - & 20 \\
\hline & & $07-23-86$ & $<5$ & 46 & 4 & $<1$ & $<1$ & $<1$ & 55 & 4 & 4 \\
\hline HS $85-22 c 2$ & 401625107313101 & $08-10-86$ & $<5$ & 55 & 31 & $<1$ & $<1$ & $<1$ & 670 & 1 & 35 \\
\hline HS $85-22 c 1$ & 401625107313102 & $08-10-86$ & $<5$ & 130 & 77 & $<1$ & 5 & $<1$ & 1,800 & 4 & 44 \\
\hline HS85-34c4 & 401748107333601 & $07-27-86$ & $<5$ & 36 & 120 & 1 & 1 & $<1$ & 1,100 & 1 & 72 \\
\hline HS85-34-2 & 401747107333602 & $07-29-86$ & $<5$ & 15 & 9 & $<1$ & $<1$ & $<1$ & 290 & 1 & 18 \\
\hline HS85-35c4 & 401745107341301 & $07-30-86$ & $<5$ & 33 & 440 & 3 & 10 & $<1$ & 720 & $<1$ & 15 \\
\hline HS85-35c1 & 401745107341302 & $07-29-86$ & $<5$ & 80 & 580 & 3 & 9 & $<1$ & 1,800 & 6 & 40 \\
\hline HS $85-38 \mathrm{cl}$ & 401735107344902 & $07-27-86$ & $<5$ & 19 & 44 & 1 & 3 & $<1$ & 190 & 1 & 25 \\
\hline HS85-24c & 401646107314601 & $09-18-85$ & -- & 59 & 8 & $<1$ & $<1$ & -- & 550 & - & 16 \\
\hline HSWl & 401726107312301 & $08-12-86$ & $<5$ & 51 & 56 & $<1$ & 2 & $<1$ & 840 & $<1$ & 4 \\
\hline HSW2 & 401726107312302 & $08-12-86$ & $<5$ & 59 & 74 & $<1$ & 14 & $<1$ & 1,100 & $<1$ & 23 \\
\hline
\end{tabular}


Table 6.--Water-quality data for valley-fill wells

$\left[\mu \mathrm{S} / \mathrm{cm}\right.$, microsiemens per centimeter at 25 degrees Celsius; ${ }^{\circ} \mathrm{C}$, degrees Celsius; mg/L, milligrams per liter; $<$, less than; $\mu_{g} / L$, micrograms per liter]

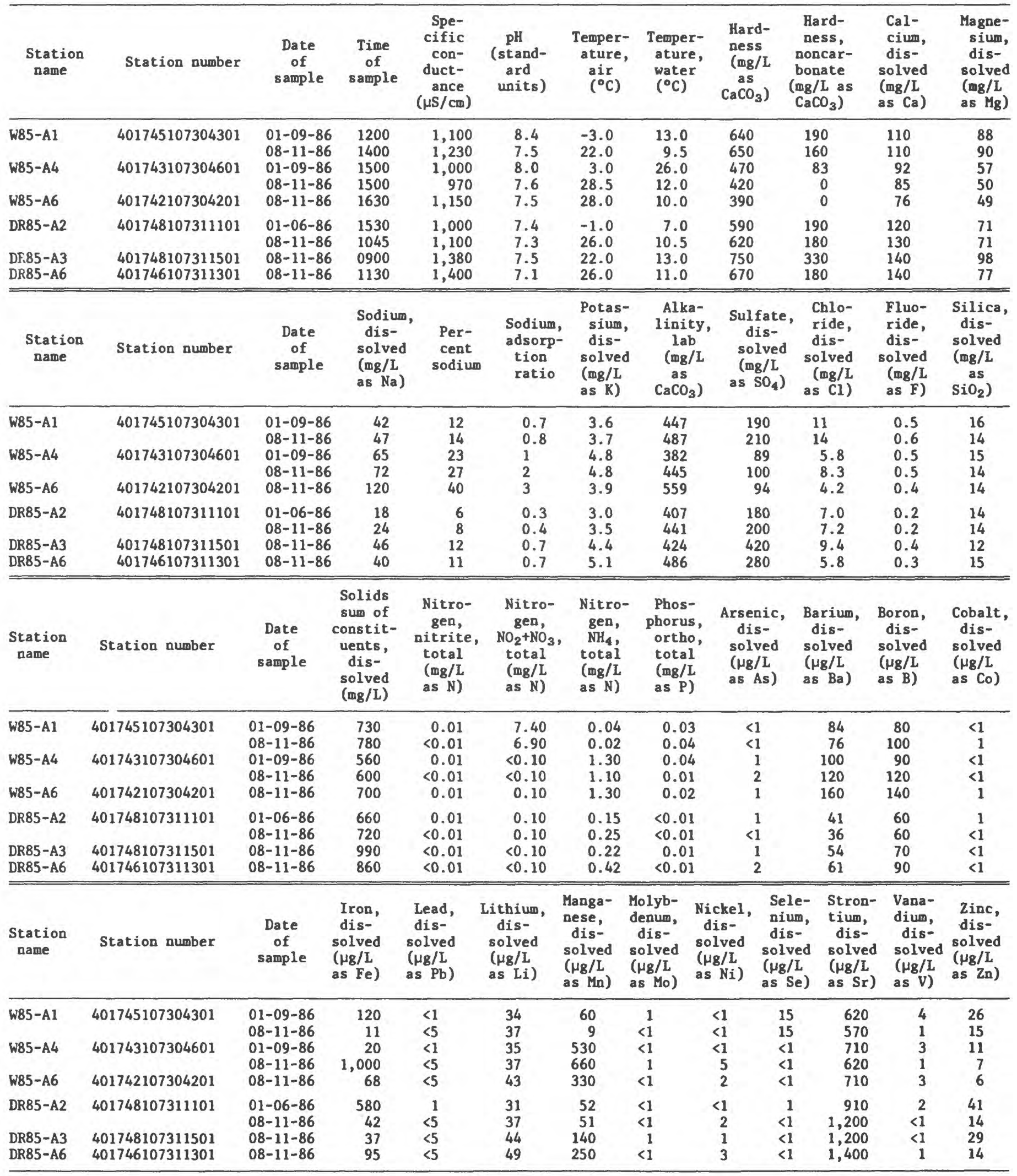


Table 7.--Water-quality data for springs

[ $\mu \mathrm{S} / \mathrm{cm}$, microsiemens per centimeter at 25 degrees Celsius; ${ }^{\circ} \mathrm{C}$, degrees Celsius; mg/L, milligrams per liter; $<$, less than; --, no data; $\mu_{g} / L$, micrograms per liter]

\begin{tabular}{|c|c|c|c|c|c|c|c|c|c|c|c|c|}
\hline $\begin{array}{l}\text { Station } \\
\text { name }\end{array}$ & Station number & $\begin{array}{l}\text { Date } \\
\text { of } \\
\text { sample }\end{array}$ & $\begin{array}{l}\text { Time } \\
\text { of } \\
\text { sample }\end{array}$ & $\begin{array}{l}\text { Spe- } \\
\text { cific } \\
\text { con- } \\
\text { duct- } \\
\text { ance } \\
(\mu S / \mathrm{cm})\end{array}$ & $\begin{array}{r}\text { pl } \\
\text { (st } \\
\text { a) } \\
\text { un }\end{array}$ & $\begin{array}{l}\text { ind- } \\
\text { ds) }\end{array}$ & $\begin{array}{l}\text { Temper- } \\
\text { ature, } \\
\text { air } \\
\left({ }^{\circ} \mathrm{C}\right)\end{array}$ & $\begin{array}{c}\text { Temper- } \\
\text { ature, } \\
\text { water } \\
\left({ }^{\circ} \mathrm{C}\right)\end{array}$ & $\begin{array}{l}\text { Hard- } \\
\text { ness } \\
(\mathrm{mg} / \mathrm{L} \\
\mathrm{as} \\
\mathrm{CaCO}_{3}\end{array}$ & $\begin{array}{r}\text { Har } \\
\text { nes } \\
\text { nonc } \\
\text { bon } \\
\text { (mg/ } \\
\mathrm{CaC}\end{array}$ & $\begin{array}{l}\text { d- } \\
\text { ar- } \\
\text { ate } \\
\text { as } \\
D_{3} \text { ) }\end{array}$ & $\begin{array}{l}\text { Calcium, } \\
\text { dis- } \\
\text { solved } \\
(\mathrm{mg} / \mathrm{L} \\
\text { as } \mathrm{Ca})\end{array}$ \\
\hline $\begin{array}{l}\text { HSS1 } \\
\text { HSS3 } \\
\text { HSS4 } \\
\text { HSS5 } \\
\text { HSS6 }\end{array}$ & $\begin{array}{l}401815107364801 \\
401819107362601 \\
401813107362501 \\
401825107334601 \\
401911107325901\end{array}$ & $\begin{array}{l}08-27-85 \\
08-27-85 \\
08-27-85 \\
08-21-85 \\
08-27-85\end{array}$ & $\begin{array}{l}1500 \\
1030 \\
1150 \\
1330 \\
1730\end{array}$ & $\begin{array}{r}1,200 \\
2,200 \\
1,040 \\
825 \\
555\end{array}$ & $\begin{array}{l}0 \\
0 \\
5 \\
5\end{array}$ & & $\begin{array}{l}-- \\
-- \\
-- \\
--\end{array}$ & $\begin{array}{r}9.0 \\
11.0 \\
13.0 \\
12.5 \\
13.0\end{array}$ & $\begin{array}{r}710 \\
1,500 \\
630 \\
490 \\
320\end{array}$ & $\begin{array}{r}1 \\
1,2 \\
2 \\
1\end{array}$ & $\begin{array}{l}90 \\
00 \\
00 \\
00 \\
70\end{array}$ & $\begin{array}{r}160 \\
350 \\
140 \\
140 \\
84\end{array}$ \\
\hline $\begin{array}{l}\text { HSS7 } \\
\text { HSS8 } \\
\text { HSS9 } \\
\text { HSS10 } \\
\text { HSS12 }\end{array}$ & $\begin{array}{l}401919107325701 \\
401827107321601 \\
401817107321601 \\
401706107313301 \\
401744107304401\end{array}$ & $\begin{array}{l}08-28-85 \\
08-21-85 \\
08-28-85 \\
08-12-86 \\
08-11-86\end{array}$ & $\begin{array}{l}1000 \\
1530 \\
1145 \\
1100 \\
1430\end{array}$ & $\begin{array}{r}1,100 \\
935 \\
1,100 \\
700 \\
1,100\end{array}$ & $\begin{array}{l}7 . \\
8 . \\
7 \\
7 . \\
7\end{array}$ & & $\begin{array}{r}-- \\
-- \\
20.0 \\
28.0\end{array}$ & $\begin{array}{r}6.0 \\
20.0 \\
14.0 \\
7.0 \\
9.5\end{array}$ & $\begin{array}{l}650 \\
560 \\
680 \\
370 \\
550\end{array}$ & & $\begin{array}{l}30 \\
10 \\
70 \\
0 \\
72\end{array}$ & $\begin{array}{r}160 \\
130 \\
110 \\
98 \\
100\end{array}$ \\
\hline $\begin{array}{l}\text { HSS13 } \\
\text { HSS14 } \\
\text { HSS } 15 \\
\text { HSS16 } \\
\text { HSS17 }\end{array}$ & $\begin{array}{l}401748107311102 \\
401902107315101 \\
401752107310501 \\
401729107312301 \\
401613107325201\end{array}$ & $\begin{array}{l}08-11-86 \\
01-14-87 \\
10-08-86 \\
10-09-86 \\
10-07-86\end{array}$ & $\begin{array}{l}1130 \\
1300 \\
0930 \\
0900 \\
1600\end{array}$ & $\begin{array}{r}875 \\
8,000 \\
1,750 \\
1,000 \\
1,000\end{array}$ & $\begin{array}{l}7 . \\
7 . \\
7 . \\
7 . \\
7 .\end{array}$ & & $\begin{array}{r}26.0 \\
=- \\
=- \\
=-\end{array}$ & $\begin{array}{r}13.0 \\
2.5 \\
6.5 \\
5.0 \\
12.5\end{array}$ & $\begin{array}{r}500 \\
5,100 \\
880 \\
510 \\
520\end{array}$ & $\begin{array}{r}4,7 \\
4 \\
1 \\
1\end{array}$ & $\begin{array}{l}93 \\
00 \\
50 \\
90 \\
90\end{array}$ & $\begin{array}{l}110 \\
380 \\
170 \\
130 \\
130\end{array}$ \\
\hline $\begin{array}{l}\text { HSS18 } \\
\text { HSS19 } \\
\text { HSS20 }\end{array}$ & $\begin{array}{l}401504107310801 \\
401657107312901 \\
401730107312501\end{array}$ & $\begin{array}{l}10-06-86 \\
10-08-86 \\
10-09-86\end{array}$ & $\begin{array}{l}1630 \\
1300 \\
0930\end{array}$ & $\begin{array}{r}7,000 \\
775 \\
920\end{array}$ & $\begin{array}{l}7 . \\
7 . \\
7 .\end{array}$ & & $\begin{array}{l}-- \\
--\end{array}$ & $\begin{array}{r}11.0 \\
6.5 \\
7.5\end{array}$ & $\begin{array}{r}2,900 \\
390 \\
490\end{array}$ & 2,4 & $\begin{array}{l}00 \\
30 \\
75\end{array}$ & $\begin{array}{l}470 \\
100 \\
120\end{array}$ \\
\hline $\begin{array}{l}\text { Station } \\
\text { name }\end{array}$ & Station number & $\begin{array}{c}\text { Date } \\
\text { of } \\
\text { sample }\end{array}$ & $\begin{array}{l}\text { Magne- } \\
\text { sium, } \\
\text { dis- } \\
\text { solved } \\
\text { (mg/L } \\
\text { as } \mathrm{Mg} \text { ) }\end{array}$ & $\begin{array}{l}\text { Sodium, } \\
\text { dis- } \\
\text { solved } \\
(\mathrm{mg} / \mathrm{L} \\
\text { as } \mathrm{Na})\end{array}$ & $\begin{array}{l}\text { Per- } \\
\text { cent } \\
\text { sodium }\end{array}$ & $\begin{array}{l}\text { Sodium } \\
\text { ad- } \\
\text { sorp- } \\
\text { tion } \\
\text { ratio }\end{array}$ & $\begin{array}{l}\text { Potas- } \\
\text { sium, } \\
\text { dis- } \\
\text { solved } \\
(\mathrm{mg} / \mathrm{L} \\
\text { as } \mathrm{K})\end{array}$ & $\begin{array}{l}\text { Alka- } \\
\text { linity, } \\
\text { lab } \\
\left(\mathrm{mg}_{\mathrm{g}} / \mathrm{L}\right. \\
\text { as } \\
\left.\mathrm{CaCO}_{3}\right)\end{array}$ & $\begin{array}{l}\text { Sul- } \\
\text { fate, } \\
\text { dis- } \\
\text { solved } \\
\left(\mathrm{mg}_{\mathrm{g}} / \mathrm{L}\right. \\
\left.\text { as } \mathrm{SO}_{4}\right)\end{array}$ & $\begin{array}{l}\text { Chlo- } \\
\text { ride, } \\
\text { dis- } \\
\text { solved } \\
(\text { (m/L } \\
\text { as } \mathrm{Cl})\end{array}$ & $\begin{array}{l}\text { Fluo- } \\
\text { ride, } \\
\text { dis- } \\
\text { solved } \\
(\mathrm{mg} / \mathrm{L} \\
\text { as } \mathrm{F})\end{array}$ & $\begin{array}{l}\text { Silica, } \\
\text { dis- } \\
\text { solved } \\
(\mathrm{mg} / \mathrm{L} \\
\mathrm{as} \\
\left.\mathrm{SiO}_{2}\right)\end{array}$ \\
\hline $\begin{array}{l}\text { HSS1 } \\
\text { HSS3 } \\
\text { HSS4 } \\
\text { HSS5 } \\
\text { HSS6 }\end{array}$ & $\begin{array}{l}401815107364801 \\
401819107362601 \\
401813107362501 \\
401825107334601 \\
401911107325901\end{array}$ & $\begin{array}{l}08-27-85 \\
08-27-85 \\
08-27-85 \\
08-21-85 \\
08-27-85\end{array}$ & $\begin{array}{r}74 \\
160 \\
68 \\
35 \\
26\end{array}$ & $\begin{array}{l}22 \\
40 \\
15 \\
7.8 \\
6.3\end{array}$ & $\begin{array}{l}6 \\
5 \\
5 \\
3 \\
4\end{array}$ & $\begin{array}{l}0.4 \\
0.5 \\
0.3 \\
0.2 \\
0.2\end{array}$ & $\begin{array}{l}4.3 \\
4.9 \\
3.6 \\
3.4 \\
1.6\end{array}$ & $\begin{array}{l}514 \\
326 \\
432 \\
394 \\
247\end{array}$ & $\begin{array}{r}190 \\
1,100 \\
240 \\
97 \\
51\end{array}$ & $\begin{array}{l}4.5 \\
9.8 \\
4.3 \\
4.2 \\
5.2\end{array}$ & $\begin{array}{l}0.2 \\
0.9 \\
0.3 \\
0.2 \\
0.3\end{array}$ & $\begin{array}{l}17 \\
22 \\
16 \\
14 \\
20\end{array}$ \\
\hline $\begin{array}{l}\text { HSS7 } \\
\text { HSS8 } \\
\text { HSS9 } \\
\text { HSS10 } \\
\text { HSS12 }\end{array}$ & $\begin{array}{l}401919107325701 \\
401827107321601 \\
401817107321601 \\
401706107313301 \\
401744107304401\end{array}$ & $\begin{array}{l}08-28-85 \\
08-21-85 \\
08-28-85 \\
08-12-86 \\
08-11-86\end{array}$ & $\begin{array}{l}61 \\
58 \\
99 \\
30 \\
73\end{array}$ & $\begin{array}{l}23 \\
12 \\
11 \\
17 \\
36\end{array}$ & $\begin{array}{r}7 \\
4 \\
3 \\
9 \\
12\end{array}$ & $\begin{array}{l}0.4 \\
0.2 \\
0.2 \\
0.4 \\
0.7\end{array}$ & $\begin{array}{l}3.6 \\
3.0 \\
1.9 \\
2.7 \\
4.1\end{array}$ & $\begin{array}{l}317 \\
357 \\
416 \\
303 \\
479\end{array}$ & $\begin{array}{r}310 \\
180 \\
230 \\
44 \\
150\end{array}$ & $\begin{array}{l}9.6 \\
4.1 \\
6.9 \\
4.0 \\
13\end{array}$ & $\begin{array}{l}0.3 \\
0.3 \\
0.3 \\
0.3 \\
0.5\end{array}$ & $\begin{array}{l}22 \\
20 \\
13 \\
13 \\
14\end{array}$ \\
\hline $\begin{array}{l}\text { HSS } 13 \\
\text { HSS } 14 \\
\text { HSS } 15 \\
\text { HSS16 } \\
\text { HSS } 17\end{array}$ & $\begin{array}{l}401748107311102 \\
401902107315101 \\
401752107310501 \\
401729107312301 \\
401613107325201\end{array}$ & $\begin{array}{l}08-11-86 \\
01-14-87 \\
10-08-86 \\
10-09-86 \\
10-07-86\end{array}$ & $\begin{array}{r}55 \\
1,000 \\
110 \\
46 \\
48\end{array}$ & $\begin{array}{r}11 \\
420 \\
57 \\
20 \\
25\end{array}$ & $\begin{array}{r}5 \\
15 \\
12 \\
8 \\
9\end{array}$ & $\begin{array}{l}0.2 \\
3 \\
0.9 \\
0.4 \\
0.5\end{array}$ & $\begin{array}{l}2.3 \\
2.8 \\
6.7 \\
2.9 \\
2.8\end{array}$ & $\begin{array}{l}409 \\
345 \\
382 \\
323 \\
332\end{array}$ & $\begin{array}{r}110 \\
5,700 \\
590 \\
170 \\
240\end{array}$ & $\begin{array}{r}7.3 \\
210 \\
9.0 \\
5.3 \\
8.1\end{array}$ & $\begin{array}{l}0.2 \\
0.7 \\
0.3 \\
0.6 \\
0.6\end{array}$ & $\begin{array}{l}14 \\
10 \\
14 \\
14 \\
16\end{array}$ \\
\hline $\begin{array}{l}\text { HSS18 } \\
\text { HSS19 } \\
\text { HSS2O }\end{array}$ & $\begin{array}{l}401504107310801 \\
401657107312901 \\
401730107312501\end{array}$ & $\begin{array}{l}10-06-86 \\
10-08-86 \\
10-09-86\end{array}$ & $\begin{array}{r}410 \\
34 \\
45\end{array}$ & $\begin{array}{l}400 \\
5.5 \\
12\end{array}$ & $\begin{array}{r}23 \\
3 \\
5\end{array}$ & $\begin{array}{l}3 \\
0.1 \\
0.2\end{array}$ & $\begin{array}{l}23 \\
1.7 \\
2.9\end{array}$ & $\begin{array}{l}393 \\
351 \\
411\end{array}$ & $\begin{array}{r}3,300 \\
29 \\
130\end{array}$ & $\begin{array}{r}140 \\
2.1 \\
8.0\end{array}$ & $\begin{array}{l}0.7 \\
0.3 \\
0.3\end{array}$ & $\begin{array}{l}11 \\
15 \\
11\end{array}$ \\
\hline
\end{tabular}


Table 7.--Water-quality data for springs--Continued

\begin{tabular}{|c|c|c|c|c|c|c|c|c|c|c|}
\hline $\begin{array}{l}\text { Station } \\
\text { name }\end{array}$ & Station number & $\begin{array}{c}\text { Date } \\
\text { of } \\
\text { sample }\end{array}$ & $\begin{array}{l}\text { Solids, } \\
\text { sum of } \\
\text { constit- } \\
\text { uents, } \\
\text { dis- } \\
\text { solved } \\
\text { (mg/L) }\end{array}$ & $\begin{array}{l}\text { Nitro- } \\
\text { gen, } \\
\text { nitrite, } \\
\text { total } \\
\text { (mg/L } \\
\text { as } N \text { ) }\end{array}$ & $\begin{array}{l}\text { Nitro- } \\
\text { gen, } \\
\text { nitrite, } \\
\text { dis- } \\
\text { solved } \\
\text { (mg/L } \\
\text { as } \mathrm{N} \text { ) }\end{array}$ & $\begin{array}{c}\text { Nitro- } \\
\text { gen, } \\
\mathrm{NO}_{2}+\mathrm{NO}_{3}, \\
\text { total } \\
(\mathrm{mg} / \mathrm{L} \\
\text { as } \mathrm{N})\end{array}$ & $\begin{array}{l}\text { Nitro- } \\
\text { gen, } \\
\mathrm{NO}_{2}+\mathrm{NO}_{3}, \\
\text { dis- } \\
\text { solved } \\
(\mathrm{mg} / \mathrm{L} \\
\text { as } \mathrm{N})\end{array}$ & $\begin{array}{l}\text { Nitro- } \\
\text { gen, } \\
\mathrm{NH}_{4}, \\
\text { total } \\
(\mathrm{mg} / \mathrm{L} \\
\text { as } \mathrm{N})\end{array}$ & $\begin{array}{l}\text { Nitro- } \\
\text { gen, } \\
\mathrm{NH}_{4}, \\
\text { dis- } \\
\text { solved } \\
\text { (mg/L } \\
\text { as N) }\end{array}$ & $\begin{array}{l}\text { Nitro- } \\
\text { gen, } \\
\mathrm{NH}_{4}+ \\
\text { organic, } \\
\text { dissolved } \\
\text { (mg/L } \\
\text { as } \mathrm{N})\end{array}$ \\
\hline HSS1 & 401815107364801 & $08-27-85$ & 780 & $-\infty$ & $<0.01$ & $-\infty$ & $<0.10$ & $-\infty$ & 0.23 & 0.4 \\
\hline HSS3 & 401819107362601 & $08-27-85$ & 1,900 & -- & $<0.01$ & $-\infty$ & $<0.10$ & $-\infty$ & 0.84 & 0.9 \\
\hline HSS4 & 401813107362501 & $08-27-85$ & 750 & -- & $<0.01$ & -- & $<0.10$ & -- & 0.10 & 0.3 \\
\hline HSS5 & 401825107334601 & $08-21-85$ & 540 & -- & $<0.01$ & $-\infty$ & $<0.10$ & -- & 0.05 & 0.4 \\
\hline HSS6 & 401911107325901 & $08-27-85$ & 340 & -- & $<0.01$ & -- & $<0.10$ & -- & 0.10 & 0.6 \\
\hline HSS7 & 401919107325701 & $08-28-85$ & 780 & - & $<0.01$ & - & 3.30 & - & 0.02 & 0.6 \\
\hline HSS 8 & 401827107321601 & $08-21-85$ & 620 & $-\infty$ & $<0.01$ & - & $<0.10$ & $-\infty$ & 0.14 & 1.0 \\
\hline HSS9 & 401817107321601 & $08-28-85$ & 720 & -- & $<0.01$ & -- & $<0.10$ & - & 0.01 & 0.4 \\
\hline HSS 10 & 401706107313301 & $08-12-86$ & 450 & $<0.01$ & -- & $<0.10$ & -- & 0.02 & - & - \\
\hline HSS 12 & 401744107304401 & $08-11-86$ & 680 & $<0.01$ & $-\infty$ & 4.70 & -- & $<0.01$ & -- & $-\infty$ \\
\hline HSS 13 & 401748107311102 & $08-11-86$ & 560 & $<0.01$ & -- & $<0.10$ & -- & 0.02 & - & - \\
\hline HSS14 & 401902107315101 & $01-14-87$ & 8,000 & -- & $<0.01$ & - & 120 & - & 0.30 & 2.6 \\
\hline HSS 15 & 401752107310501 & $10-08-86$ & 1,200 & -- & $<0.01$ & -- & 1.10 & -- & 0.09 & 0.5 \\
\hline HSS 16 & 401729107312301 & $10-09-86$ & 580 & -- & $<0.01$ & $\cdots$ & $<0.10$ & -- & 0.09 & 0.8 \\
\hline HSS 17 & 401613107325201 & $10-07-86$ & 670 & -- & $<0.01$ & -- & $<0.10$ & -- & 0.17 & 1.4 \\
\hline HSS18 & 401504107310801 & $10-06-86$ & 5,000 & -- & 0.04 & $\ldots$ & 0.80 & -- & 0.24 & 1.7 \\
\hline HSS 19 & 401657107312901 & $10-08-86$ & 400 & $-\infty$ & $<0.01$ & -- & $<0.10$ & -- & 0.09 & 0.2 \\
\hline HSS2O & 401730107312501 & $10-09-86$ & 580 & -- & $<0.01$ & -- & 1.60 & -- & 0.22 & 0.5 \\
\hline $\begin{array}{l}\text { Station } \\
\text { name }\end{array}$ & Station number & $\begin{array}{c}\text { Date } \\
\text { of } \\
\text { sample }\end{array}$ & $\begin{array}{l}\text { Phos- } \\
\text { phorus, } \\
\text { dis- } \\
\text { solved } \\
\text { (mg/L } \\
\text { as P) }\end{array}$ & $\begin{array}{c}\text { Phos- } \\
\text { phorus, } \\
\text { ortho, } \\
\text { total } \\
\text { (mg/L } \\
\text { as P) }\end{array}$ & $\begin{array}{c}\text { Phos- } \\
\text { phorus, } \\
\text { ortho, } \\
\text { dis- } \\
\text { solved } \\
\text { (mg/L } \\
\text { as P) }\end{array}$ & $\begin{array}{c}\text { Arsenic, } \\
\text { dis- } \\
\text { solved } \\
(\mu g / L \\
\text { as As) }\end{array}$ & $\begin{array}{l}\text { Barium, } \\
\text { dis- } \\
\text { solved } \\
\left(\mu_{g} / \mathrm{L}\right. \\
\text { as } \mathrm{Ba}) .\end{array}$ & $\begin{array}{c}\text { Boron, } \\
\text { dis- } \\
\text { solved } \\
(\mu g / L \\
\text { as B) }\end{array}$ & $\begin{array}{c}\text { Cobalt, } \\
\text { dis- } \\
\text { solved } \\
(\mu g / L \\
\text { as Co })\end{array}$ & $\begin{array}{l}\text { Iron, } \\
\text { dis- } \\
\text { solved } \\
\left(\mu_{g} / \mathrm{L}\right. \\
\text { as } \mathrm{Fe})\end{array}$ \\
\hline HSS 1 & 401815107364801 & $08-27-85$ & $<0.01$ & -- & $<0.01$ & 1 & 39 & 130 & 1 & 930 \\
\hline HSS3 & 401819107362601 & $08-27-85$ & $<0.01$ & -- & $<0.01$ & 2 & $<100$ & 280 & 5 & 8,900 \\
\hline HSS4 & 401813107362501 & $08-27-85$ & $<0.01$ & -- & $<0.01$ & 2 & 35 & 110 & 1 & 380 \\
\hline HSS5 & 401825107334601 & $08-21-85$ & 0.02 & -- & $<0.01$ & $<1$ & 170 & 40 & $<1$ & 130 \\
\hline HSS6 & 401911107325901 & $08-27-85$ & $<0.01$ & -- & $<0.01$ & 1 & 110 & 60 & 1 & 940 \\
\hline HSS7 & 401919107325701 & $08-28-85$ & 0.04 & -- & 0.02 & 1 & 100 & 90 & $<1$ & 8 \\
\hline HSS8 & 401827107321601 & $08-21-85$ & $<0.01$ & -- & $<0.01$ & 2 & 120 & 40 & 1 & 43 \\
\hline HSS9 & 401817107321601 & $08-28-85$ & $<0.01$ & - & $<0.01$ & 1 & 85 & 110 & 1 & 37 \\
\hline HSS 10 & 401706107313301 & $08-12-86$ & - & 0.02 & - & $<1$ & 81 & 40 & $<1$ & 16 \\
\hline HSS12 & 401744107304401 & $08-11-86$ & -- & 0.03 & $-\infty$ & $<1$ & 100 & 100 & $<1$ & 12 \\
\hline HSS13 & 401748107311102 & $08-11-86$ & - & 0.03 & -- & $<1$ & 71 & 60 & 1 & $<3$ \\
\hline HSS 14 & 401902107315101 & $01-14-87$ & 0.01 & $-\infty$ & $<0.01$ & $<1$ & $<100$ & 170 & $<1$ & 60 \\
\hline HSS 15 & 401752107310501 & $10-08-86$ & $<0.01$ & -- & $<0.01$ & $<1$ & 19 & 70 & 2 & 5 \\
\hline HSS16 & 401729107312301 & $10-09-86$ & 0.75 & -- & $<0.01$ & $<1$ & 81 & 40 & $<1$ & 18 \\
\hline HSS 17 & 401613107325201 & $10-07-86$ & 0.02 & -- & $<0.01$ & $<1$ & 70 & 60 & 6 & 11 \\
\hline HSS 18 & 401504107310801 & $10-06-86$ & 0.02 & - & $<0.01$ & $<1$ & $<100$ & 110 & 1 & 60 \\
\hline HSS 19 & 401657107312901 & $10-08-86$ & $<0.01$ & -- & $<0.01$ & $<1$ & 21 & 20 & $<1$ & $<3$ \\
\hline HSS2O & 401730107312501 & $10-09-86$ & 0.02 & -- & $<0.01$ & $<1$ & 220 & 40 & $<1$ & 5 \\
\hline
\end{tabular}


Table 7.--Water-quality data for springs--Continued

\begin{tabular}{|c|c|c|c|c|c|c|c|c|c|c|c|}
\hline $\begin{array}{l}\text { Station } \\
\text { name }\end{array}$ & Station number & $\begin{array}{c}\text { Date } \\
\text { of } \\
\text { sample }\end{array}$ & $\begin{array}{l}\text { Lead, } \\
\text { dis- } \\
\text { solved } \\
\left(\mu_{\mathrm{g}} / \mathrm{L}\right. \\
\text { s } \mathrm{Pb})\end{array}$ & $\begin{array}{l}\text { Lithium, } \\
\text { dis- } \\
\text { solved } \\
(\mu g / L \\
\text { as Li) }\end{array}$ & $\begin{array}{c}\text { Manga- } \\
\text { nese, } \\
\text { dis- } \\
\text { solved } \\
(\mu g / L \\
\text { as } \mathrm{Mn})\end{array}$ & $\begin{array}{c}\text { Molyb- } \\
\text { denum, } \\
\text { dis- } \\
\text { solved } \\
(\mu g / L \\
\text { as } \mathrm{Mo})\end{array}$ & $\begin{array}{l}\text { Nickel, } \\
\text { dis- } \\
\text { solved } \\
\left(\mu_{g} / L\right. \\
\text { as } \mathrm{Ni})\end{array}$ & $\begin{array}{l}\text { Sele- } \\
\text { nium, } \\
\text { dis- } \\
\text { solved } \\
\left(\mu_{8} / L\right. \\
\text { as } \mathrm{Se})\end{array}$ & $\begin{array}{l}\text { Stron- } \\
\text { tium, } \\
\text { dis- } \\
\text { solved } \\
(\mu g / L \\
\text { as } S r)\end{array}$ & $\begin{array}{l}\text { Vana- } \\
\text { dium, } \\
\text { dis- } \\
\text { solved } \\
\left(\mu_{g} / L\right. \\
\text { as V) }\end{array}$ & $\begin{array}{l}\text { Zinc, } \\
\text { dis- } \\
\text { solved } \\
\left(\mu_{g} / L\right. \\
\left.\text { as } \mathrm{Zn}_{n}\right)\end{array}$ \\
\hline HSS1 & 401815107364801 & $08-27-85$ & -- & 48 & 150 & $<1$ & $<1$ & -- & 780 & -- & 9 \\
\hline HSS3 & 401819107362601 & $08-27-85$ & -- & $<10$ & 920 & $<1$ & 10 & -- & 1,300 & -- & 20 \\
\hline HSS4 & 401813107362501 & $08-27-85$ & -- & 42 & 130 & 1 & 4 & -- & 700 & -- & 9 \\
\hline HSS5 & 401825107334601 & $08-21-85$ & -- & 20 & 92 & $<1$ & 2 & -- & 510 & -- & 13 \\
\hline HSS6 & 401911107325901 & $08-27-85$ & -- & 17 & 510 & 1 & 3 & -- & 220 & -- & 10 \\
\hline HSS7 & 401919107325701 & $08-28-85$ & -- & 41 & $<1$ & $<1$ & $<1$ & -- & 930 & -- & 9 \\
\hline HSS8 & 401827107321601 & $08-21-85$ & -- & 25 & 580 & 1 & 1 & -- & 440 & -- & 9 \\
\hline HSS9 & 401817107321601 & $08-28-85$ & -- & 26 & 63 & $i$ & 3 & -- & 800 & -- & 13 \\
\hline HSS 10 & 401706107313301 & $08-12-86$ & $<5$ & 28 & 25 & 4 & 1 & 1 & 270 & 1 & $<3$ \\
\hline HSS 12 & 401744107304401 & $08-11-86$ & $<5$ & 40 & 8 & 1 & 6 & 8 & 790 & 1 & 11 \\
\hline HSS 13 & 401748107311102 & $08-11-86$ & $<5$ & 24 & $<1$ & $<1$ & 3 & 1 & 320 & 1 & 9 \\
\hline HSS 14 & 401902107315101 & $01-14-87$ & $<5$ & 210 & 30 & 6 & 4 & 120 & 6,000 & 6 & 20 \\
\hline HSS 15 & 401752107310501 & $10-08-86$ & $<5$ & 94 & 2 & 8 & 2 & 3 & 2,300 & 1 & 17 \\
\hline HSS 16 & 401729107312301 & $10-09-86$ & $<5$ & 38 & 550 & 8 & $<1$ & 2 & 230 & 2 & 12 \\
\hline HSS 17 & 401613107325201 & $10-07-86$ & $<5$ & 52 & 660 & 9 & 7 & $<1$ & 1,000 & 1 & 5 \\
\hline HSS 18 & 401504107310801 & $10-06-86$ & $<5$ & 620 & 30 & 11 & 3 & 270 & 9,100 & 2 & 30 \\
\hline HSS 19 & 401657107312901 & $10-08-86$ & $<5$ & 23 & 4 & 8 & 1 & 1 & 230 & 1 & 9 \\
\hline HSS2O & 401730107312501 & $10-09-86$ & $<5$ & 32 & 96 & 11 & $<1$ & 2 & 600 & 2 & 9 \\
\hline
\end{tabular}


$\left[\mathrm{ft}^{3} / \mathrm{s}\right.$, cubic feet per second; $\mu \mathrm{S} / \mathrm{cm}$, microsiemens per centimeter at 25 degrees Celsius; <, less than; ${ }^{\circ} \mathrm{C}$, degrees Celsius; mg/L, milligrams per liter, -., no data; $\mu g / L$, micrograms per liter]

\begin{tabular}{|c|c|c|c|c|c|c|c|c|}
\hline $\begin{array}{l}\text { Station } \\
\text { name }\end{array}$ & Station number & $\begin{array}{l}\text { Date } \\
\text { of } \\
\text { sample }\end{array}$ & $\begin{array}{c}\text { Time } \\
\text { of } \\
\text { sample }\end{array}$ & $\begin{array}{c}\text { Stream- } \\
\text { flow, } \\
\text { instan- } \\
\text { taneous } \\
\left(\mathrm{ft}^{3} / \mathrm{s}\right)\end{array}$ & $\begin{array}{l}\text { Specific } \\
\text { conduct- } \\
\text { ance } \\
(\mu \mathrm{S} / \mathrm{cm})\end{array}$ & $\begin{array}{l}\text { pH } \\
\text { (stand- } \\
\text { ard } \\
\text { units }\end{array}$ & $\begin{array}{c}\text { Temper- } \\
\text { ature, } \\
\text { air } \\
\left({ }^{\circ} \mathrm{C}\right)\end{array}$ & $\begin{array}{l}\text { Temper- } \\
\text { ature, } \\
\text { water } \\
\left({ }^{\circ} \mathrm{C}\right)\end{array}$ \\
\hline DR1 & 401608107304601 & $08-28-86$ & 1230 & 0.06 & 425 & 8.1 & $-\infty$ & 14.0 \\
\hline DR9 - . & 401731107312101 & $08-28-86$ & 1130 & 0.27 & 703 & 8.1 & - & 15.5 \\
\hline DR10 & 401732107312201 & $08-28-86$ & 1100 & 0.08 & 1,070 & 7.9 & $-\infty$ & 11.5 \\
\hline DR11 & 401733107312201 & $08-28-86$ & 1105 & 0.48 & 775 & 8.0 & -- & 13.5 \\
\hline \multirow{6}{*}{$\begin{array}{l}\text { Deep Rock } \\
\text { Gulch near } \\
\text { Hamilton } \\
\text { (DR13) }\end{array}$} & \multirow[t]{6}{*}{09249455} & $09-29-85$ & 1350 & - & 930 & 8.4 & - & 8.0 \\
\hline & & $01-08-86$ & 1300 & 0.36 & 900 & 8.5 & -2.0 & 0.0 \\
\hline & & $05-07-86$ & 1700 & 8.6 & 400 & 7.9 & 6.5 & 4.5 \\
\hline & & $07-30-86$ & 0925 & $\ldots$ & 810 & 8.3 & 25.0 & 7.5 \\
\hline & & $08-28-86$ & 1420 & 0.51 & 784 & 8.1 & - & 19.5 \\
\hline & & $10-07-86$ & 0940 & 0.66 & 821 & 8.4 & -- & 4.5 \\
\hline W2-n-n & 401650107291501 & $08-27-86$ & 0950 & 0.13 & 1,030 & 8.1 & $-\infty$ & 14.0 \\
\hline W5- & 401734107302801 & $08-27-86$ & 0945 & 0.42 & 1,160 & 8.0 & $-\infty$ & 11.0 \\
\hline \multirow{5}{*}{$\begin{array}{l}\text { Waddle Creek } \\
\text { near Pagoda } \\
\text { (W8) }\end{array}$} & \multirow[t]{5}{*}{09249450} & $01-08-86$ & 1045 & 0.64 & 1,080 & 8.3 & -5.0 & 0.0 \\
\hline & & $05-08-86$ & 1020 & 4.1 & 1,000 & 8.4 & 3.0 & 2.5 \\
\hline & & $07-30-86$ & 0840 & - & 1,000 & 8.3 & 25.0 & 10.0 \\
\hline & & $08-27-86$ & 1315 & 0.75 & 1,060 & 8.0 & - & 16.5 \\
\hline & & $10-07-86$ & 1245 & 0.65 & 1,140 & 8.2 & - & 7.5 \\
\hline \multirow[t]{2}{*}{ W10 } & \multirow[t]{2}{*}{401753107305701} & $09-29-85$ & 1310 & - & 1,100 & 8.4 & $-\infty$ & 5.0 \\
\hline & & $08-27-86$ & 1500 & 0.78 & 1,030 & 8.1 & $-\infty$ & 18.5 \\
\hline W12- - & 401807107310501 & $08-27-86$ & 1700 & -- & 885 & 8.4 & -- & 22.0 \\
\hline W13 & 401816107311601 & $08-27-86$ & 1730 & 1.1 & 933 & 8.4 & $-\infty$ & 17.5 \\
\hline W15 (Hart & 401847107314601 & $08-27-86$ & 1730 & - & 1,170 & 8.0 & -- & - \\
\hline $\begin{array}{l}\text { Gulch near } \\
\text { mouth) }\end{array}$ & & $10-07-86$ & 1100 & -- & 1,450 & 8.4 & -- & 6.0 \\
\hline W17- & 402000107315601 & $08-27-86$ & 1730 & -- & 988 & 8.1 & -- & - \\
\hline $\begin{array}{l}\text { North Fork } \\
\text { Deer Creek }\end{array}$ & 401532107340401 & $10-07-86$ & 1655 & -- & 1,010 & 8.2 & -- & 12.5 \\
\hline HSP1 1 & 401529107273501 & $08-06-86$ & 1030 & -- & 150 & 9.4 & 21.5 & 18.0 \\
\hline
\end{tabular}

\begin{tabular}{|c|c|c|c|c|c|c|c|c|c|c|c|}
\hline $\begin{array}{l}\text { Station } \\
\text { name }\end{array}$ & Station number & $\begin{array}{c}\text { Date } \\
\text { of } \\
\text { sample }\end{array}$ & $\begin{array}{l}\text { Oxy- } \\
\text { gen, } \\
\text { dis- } \\
\text { solved } \\
(\mathrm{mg} / \mathrm{L})\end{array}$ & $\begin{array}{l}\text { Hard- } \\
\text { ness } \\
(\mathrm{mg} / \mathrm{L} \\
\text { as } \\
\left.\mathrm{CaCO}_{3}\right)\end{array}$ & $\begin{array}{c}\text { Hard- } \\
\text { ness, } \\
\text { noncar- } \\
\text { bonate } \\
\left(\mathrm{mg}^{2} / \mathrm{L} \text { as }\right. \\
\left.\mathrm{CaCO}_{3}\right)\end{array}$ & $\begin{array}{l}\text { Cal- } \\
\text { cium, } \\
\text { dis- } \\
\text { solved } \\
\text { (mg/L } \\
\text { as Ca) }\end{array}$ & $\begin{array}{l}\text { Magne- } \\
\text { sium, } \\
\text { dis- } \\
\text { solved } \\
(\mathrm{mg} / \mathrm{L} \\
\text { as } \mathrm{M})\end{array}$ & $\begin{array}{l}\text { Sodium, } \\
\text { dis- } \\
\text { solved } \\
(\mathrm{mg} / \mathrm{L} \\
\text { as } \mathrm{Na})\end{array}$ & $\begin{array}{l}\text { Per- } \\
\text { cent } \\
\text { sodium }\end{array}$ & $\begin{array}{c}\text { Sodium } \\
\text { ad- } \\
\text { sorp- } \\
\text { tion } \\
\text { ratio }\end{array}$ & $\begin{array}{l}\text { Potas- } \\
\text { sium, } \\
\text { dis- } \\
\text { solved } \\
\text { (mg/L } \\
\text { as K) }\end{array}$ \\
\hline DR1 $1 \cdots \cdots$ & 401608107304601 & $08-28-86$ & -- & 230 & 41 & 56 & 22 & 4.7 & 4 & 0.1 & 2.1 \\
\hline DR9 - - & 401731107312101 & $08-28-86$ & 8.2 & 380 & 130 & 79 & 45 & 19 & 10 & 0.4 & 2.8 \\
\hline DR10 - & 401732107312201 & $08-28-86$ & 8.3 & 350 & 0 & 77 & 39 & 130 & 44 & 3 & 4.1 \\
\hline DR11 & 401733107312201 & $08-28-86$ & 8.5 & 380 & 110 & 79 & 44 & 41 & 19 & 0.9 & 2.9 \\
\hline Deep Rock & 09249455 & $09-29-85$ & - & 440 & 140 & 89 & 53 & 38 & 16 & 0.8 & 3.0 \\
\hline Gulch near & & $01-08-86$ & 11.6 & 470 & 120 & 100 & 54 & 43 & 16 & 0.9 & 3.3 \\
\hline Hamilton & & $05-07-86$ & 10.0 & 200 & 45 & 48 & 20 & 6.6 & 7 & 0.2 & 2.1 \\
\hline \multirow[t]{3}{*}{ (DR13) } & & $07-30-86$ & - & 440 & 130 & 91 & 51 & 32 & 14 & 0.7 & 3.1 \\
\hline & & $08-28-86$ & 8.6 & 370 & 130 & 69 & 49 & 36 & 17 & 0.8 & 3.3 \\
\hline & & $10-07-86$ & 9.5 & 390 & 71 & 85 & 44 & 26 & 12 & 0.6 & 3.4 \\
\hline W2- - - - - & 401650107291501 & $08-27-86$ & - & 550 & 260 & 110 & 67 & 11 & 4 & 0.2 & 3.7 \\
\hline 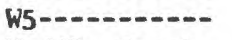 & 401734107302801 & $08-27-86$ & 8.8 & 680 & 380 & 120 & 91 & 23 & 7 & 0.4 & 4.3 \\
\hline \multirow{5}{*}{$\begin{array}{l}\text { Waddle Creek } \\
\text { near Pagoda } \\
\text { (W8) }\end{array}$} & 09249450 & $01-08-86$ & 10.9 & 650 & 270 & 130 & 78 & 30 & 9 & 0.5 & 4.6 \\
\hline & & $05-08-86$ & 10.3 & 460 & 190 & 100 & 51 & 15 & 7 & 0.3 & 3.6 \\
\hline & & $07-30-86$ & - & 580 & 270 & 110 & 74 & 29 & 10 & 0.5 & 4.3 \\
\hline & & $08-27-86$ & 7.9 & 570 & 280 & 110 & 71 & 29 & 10 & 0.5 & 4.6 \\
\hline & & $10-07-86$ & 8.3 & 650 & 320 & 130 & 78 & 31 & 9 & 0.5 & 4.8 \\
\hline \multirow[t]{2}{*}{ W10 $-\ldots-n-\infty$} & 401753107305701 & $09-29-85$ & -- & 610 & 290 & 120 & 75 & 30 & 10 & 0.5 & 4.8 \\
\hline & & $08-27-86$ & 7.4 & 550 & 310 & 98 & 74 & 29 & 10 & 0.6 & 4.6 \\
\hline W12-1. & 401807107310501 & $08-27-86$ & 7.0 & 440 & 200 & 69 & 64 & 32 & 14 & 0.7 & 4.1 \\
\hline W13 - - - & 401816107311601 & $08-27-86$ & 7.2 & 460 & 170 & 80 & 62 & 33 & 13 & 0.7 & 4.2 \\
\hline W15 (Hart & 401847107314601 & $08-27-86$ & -- & 620 & 320 & 110 & 83 & 25 & 8 & 0.4 & 3.8 \\
\hline $\begin{array}{l}\text { Gulch near } \\
\text { mouth) }\end{array}$ & & $10-07-86$ & -- & 660 & 340 & 130 & 82 & 25 & 8 & 0.4 & 3.6 \\
\hline W17 - . & 402000107315601 & $08-27-86$ & -- & 460 & 250 & 72 & 69 & 37 & 15 & 0.8 & 4.5 \\
\hline $\begin{array}{l}\text { North Fork } \\
\text { Deer Creek }\end{array}$ & 401532107340401 & $10-07-86$ & 7.9 & 560 & 300 & 110 & 68 & 23 & 8 & 0.4 & 4.6 \\
\hline HSPI $1-\cdots$ & 401529107273501 & $08-06-86$ & -- & 52 & 0 & 12 & 5.3 & 1.6 & 6 & 0.1 & 5.0 \\
\hline
\end{tabular}


Table 8.--Water-quality data for surface-water sites--Continued

\begin{tabular}{|c|c|c|c|c|c|c|c|c|}
\hline $\begin{array}{l}\text { Station } \\
\text { name }\end{array}$ & Station number & $\begin{array}{l}\text { Date } \\
\text { of } \\
\text { sample }\end{array}$ & $\begin{array}{c}\text { Alka- } \\
\text { linity, } \\
\text { lab } \\
\left(\mathrm{mg}_{\mathrm{g}} / \mathrm{L} \text { as }\right. \\
\left.\mathrm{CaCO}_{3}\right)\end{array}$ & $\begin{array}{c}\text { Sulfate, } \\
\text { dis- } \\
\text { solved } \\
\left(\mathrm{mg}^{\prime} / \mathrm{L}\right. \\
\left.\text { as } \mathrm{SO}_{4}\right)\end{array}$ & $\begin{array}{l}\text { Chloride, } \\
\text { dis- } \\
\text { solved } \\
\text { (mg/L } \\
\text { as Cl) }\end{array}$ & $\begin{array}{c}\text { Fluoride, } \\
\text { dis- } \\
\text { solved } \\
\text { (mg/L } \\
\text { as F) }\end{array}$ & $\begin{array}{l}\text { Silica, } \\
\text { dis- } \\
\text { solved } \\
\left(\mathrm{mg}_{\mathrm{g}} / \mathrm{L} \text { as }\right. \\
\left.\mathrm{SiO}_{2}\right)\end{array}$ & $\begin{array}{l}\text { Solids, } \\
\text { sum of } \\
\text { constituents } \\
\text { dissolved } \\
(\mathrm{mg} / \mathrm{L})\end{array}$ \\
\hline DR1 $1 \cdots-\cdots$ & 401608107304601 & $08-28-86$ & 190 & 36 & 1.8 & 0.5 & 16 & 250 \\
\hline DR9 & 401731107312101 & $08-28-86$ & 251 & 120 & 4.2 & 0.3 & 15 & 440 \\
\hline DR10 - & 401732107312201 & $08-28-86$ & 474 & 110 & 4.0 & 1.4 & 12 & 660 \\
\hline DR11 & 401733107312201 & $08-28-86$ & 269 & 120 & 4.1 & 0.5 & 15 & 470 \\
\hline \multirow{6}{*}{$\begin{array}{l}\text { Deep Rock } \\
\text { Gulch near } \\
\text { Hamilton } \\
\text { (DR13) }\end{array}$} & 09249455 & $09-29-85$ & 303 & 190 & 5.8 & 0.4 & 13 & 580 \\
\hline & & $01-08-86$ & 357 & 170 & 4.3 & 0.5 & 13 & 600 \\
\hline & & $05-07-86$ & 157 & 58 & 2.7 & 0.2 & 13 & 250 \\
\hline & & $07-30-86$ & 309 & 160 & 3.7 & 0.4 & 14 & 540 \\
\hline & & $08-28-86$ & 241 & 160 & 4.9 & 0.5 & 14 & 480 \\
\hline & & $10-07-86$ & 323 & 130 & 4.5 & 0.4 & 12 & 500 \\
\hline W2 $-\cdots+-\infty-\infty-\infty$ & 401650107291501 & $08-27-86$ & 291 & 270 & 6.5 & 0.3 & 12 & 660 \\
\hline 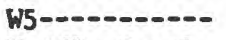 & 401734107302801 & $08-27-86$ & 298 & 360 & 10 & 0.2 & 13 & 800 \\
\hline \multirow{5}{*}{$\begin{array}{l}\text { Waddle Creek } \\
\text { near Pagoda } \\
\text { (W8) }\end{array}$} & 09249450 & $01-08-86$ & 377 & 270 & 9.1 & 0.2 & 13 & 760 \\
\hline & & $05-08-86$ & 267 & 210 & 6.0 & 0.2 & 10 & 560 \\
\hline & & $07-30-86$ & 315 & 260 & 12 & 0.2 & 14 & 690 \\
\hline & & $08-27-86$ & 284 & 280 & 12 & 0.3 & 14 & 690 \\
\hline & & $10-07-86$ & 327 & 310 & 10 & 0.2 & 14 & 780 \\
\hline \multirow[t]{2}{*}{ W10 } & 401753107305701 & $09-29-85$ & 321 & 300 & 10 & 0.2 & 13 & 750 \\
\hline & & $08-27-86$ & 244 & 280 & 12 & 0.3 & 14 & 660 \\
\hline W12- & 401807107310501 & $08-27-86$ & 241 & 230 & 7.9 & 0.3 & 11 & 560 \\
\hline W13- & 401816107311601 & $08-27-86$ & 285 & 230 & 8.0 & 0.3 & 11 & 600 \\
\hline W15 (Hart & 401847107314601 & $08-27-86$ & 296 & 320 & 11 & 0.3 & 15 & 750 \\
\hline $\begin{array}{l}\text { Gulch near } \\
\text { mouth) }\end{array}$ & & $10-07-86$ & 325 & 330 & 9.5 & 0.3 & 13 & 790 \\
\hline W17- & 402000107315601 & $08-27-86$ & 219 & 270 & 10 & 0.3 & 6.7 & 600 \\
\hline $\begin{array}{l}\text { North Fork } \\
\text { Deer Creek }\end{array}$ & 401532107340401 & $10-07-86$ & 258 & 290 & 10 & 0.2 & 11 & 670 \\
\hline HSP1 & 401529107273501 & $08-06-86$ & 56 & 7.9 & 1.2 & 0.1 & 3.2 & 70 \\
\hline
\end{tabular}

Station name
Station number

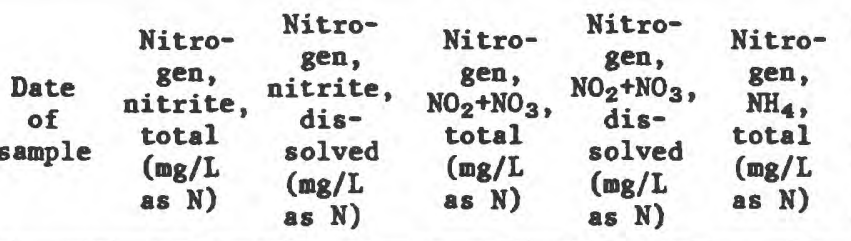

Nitro- Nitro- Phos-

gen, gen, phorus, $\mathrm{NH}_{4}, \mathrm{NH}_{4}+$ disdis- organic, solved solved dissolved (mg/L) (mg/L as N) as N)

\begin{tabular}{|c|c|c|c|c|c|c|c|c|c|c|}
\hline DR1- & 401608107304601 & $08-28-86$ & -- & -- & -- & - & -- & - & - & - \\
\hline DR9- & 401731107312101 & $08-28-86$ & -- & -- & $-\infty$ & - & -- & -- & -- & - \\
\hline DR10 & 401732107312201 & $08-28-86$ & $-\infty$ & - & -- & -- & -- & -- & - & - \\
\hline DR11 & 401733107312201 & $08-28-86$ & -- & -- & -- & -- & -- & -- & -- & -- \\
\hline \multirow{6}{*}{$\begin{array}{l}\text { Deep Rock } \\
\text { Gulch near } \\
\text { Hamilton } \\
\text { (DR13) }\end{array}$} & 09249455 & $09-29-85$ & - & 0.01 & -- & 0.17 & -- & 0.04 & 0.3 & $<0.01$ \\
\hline & & $01-08-86$ & 0.01 & -- & 0.50 & -- & 0.08 & -- & -- & -- \\
\hline & & $05-07-86$ & - & $<0.01$ & $-\infty$ & 0.37 & $=$ & 0.16 & 1.1 & 0.05 \\
\hline & & $07-30-86$ & -- & $<0.01$ & - & 0.22 & - & 0.01 & 0.2 & 0.01 \\
\hline & & $08-28-86$ & -- & -- & -- & -- & -- & -- & -- & -- \\
\hline & & $10-07-86$ & -- & $<0.01$ & -- & 0.23 & -- & 0.02 & 0.5 & 0.02 \\
\hline W2- & 401650107291501 & $08-27-86$ & -- & -- & -- & -- & -- & -- & - & -- \\
\hline W5-- & 401734107302801 & $08-27-86$ & -- & -- & -- & -- & -- & -- & -- & - \\
\hline \multirow{5}{*}{$\begin{array}{l}\text { Waddle Creek } \\
\text { near Pagoda } \\
\text { (W8) }\end{array}$} & 09249450 & $01-08-86$ & 0.01 & -- & 0.60 & -- & 0.10 & -- & - & - \\
\hline & & $05-08-86$ & -- & 0.01 & -- & 0.54 & - & 0.28 & 0.8 & 0.13 \\
\hline & & $07-30-86$ & $-\infty$ & $<0.01$ & $-\infty$ & 0.40 & $-\infty$ & 0.04 & 0.4 & 0.02 \\
\hline & & $08-27-86$ & -- & - & -- & -- & $=-$ & -- & -- & -- \\
\hline & & $10-07-86$ & -- & $<0.01$ & -- & 0.41 & -- & 0.08 & 0.2 & $<0.01$ \\
\hline \multirow[t]{2}{*}{ W10 - } & 401753107305701 & $09-29-85$ & $-\infty$ & $<0.01$ & $-\infty$ & 0.39 & - & 0.05 & 0.4 & 0.01 \\
\hline & & $08-27-86$ & -- & -- & -- & -- & -- & -- & -- & -- \\
\hline W12- & 401807107310501 & $08-27-86$ & -- & -- & -- & - & -- & -- & - & $=$ \\
\hline W13--non & 401816107311601 & $08-27-86$ & -- & -- & -- & -- & -- & -- & -- & -- \\
\hline W15 (Hart & 401847107314601 & $08-27-86$ & -- & -- & - & -- & -- & -- & - & - \\
\hline $\begin{array}{l}\text { Gulch near } \\
\text { mouth) }\end{array}$ & & $10-07-86$ & -- & $<0.01$ & - & 0.25 & -- & 0.09 & 1.7 & 0.08 \\
\hline W17-n- & 402000107315601 & $08-27-86$ & - & 0.01 & -- & 0.30 & -- & $<0.01$ & 0.6 & 0.02 \\
\hline $\begin{array}{l}\text { North Fork } \\
\text { Deer Creek }\end{array}$ & 401532107340401 & $10-07-86$ & - & $<0.01$ & $-\infty$ & $<0.10$ & - & 0.07 & 0.4 & $<0.01$ \\
\hline HSP1 1 & 401529107273501 & $08-06-86$ & - & - & - & - & - & -- & - & - \\
\hline
\end{tabular}




\begin{tabular}{|c|c|c|c|c|c|c|c|c|c|c|}
\hline $\begin{array}{l}\text { Station } \\
\text { name }\end{array}$ & Station number & $\begin{array}{l}\text { Date } \\
\text { of } \\
\text { sample }\end{array}$ & $\begin{array}{c}\text { Phos- } \\
\text { phorus, } \\
\text { ortho, } \\
\text { total } \\
\text { (mg/L } \\
\text { as P) }\end{array}$ & $\begin{array}{c}\text { Phos- } \\
\text { phorus, } \\
\text { ortho, } \\
\text { dis- } \\
\text { solved } \\
\left(\mu_{8} / \mathrm{L}\right. \\
\text { as P) }\end{array}$ & $\begin{array}{c}\text { Arsenic, } \\
\text { dis- } \\
\text { solved } \\
\left(\mu_{8} / L\right. \\
\text { as } \mathrm{As})\end{array}$ & $\begin{array}{l}\text { Barium, } \\
\text { dis- } \\
\text { solved } \\
\left(\mu_{g} / L\right. \\
\text { as } \mathrm{Ba})\end{array}$ & $\begin{array}{l}\text { Boron, } \\
\text { dis- } \\
\text { solved } \\
(\mu 8 / L \\
\text { as B) }\end{array}$ & $\begin{array}{l}\text { Cobalt, } \\
\text { dis- } \\
\text { solved } \\
\left(\mu_{8} / L\right. \\
\text { as Co })\end{array}$ & $\begin{array}{l}\text { Iron, } \\
\text { dis- } \\
\text { solved } \\
\left(\mu_{8} / \mathrm{L}\right. \\
\text { as Fe) }\end{array}$ & $\begin{array}{l}\text { Lead, } \\
\text { dis- } \\
\text { solved } \\
\left(\mu_{\mathrm{g}} / \mathrm{L}\right. \\
\text { as } \mathrm{Pb})\end{array}$ \\
\hline DR1-D. & 401608107304601 & $08-28-86$ & -- & -- & -- & - & 40 & - & -- & -- \\
\hline DR9 & 401731107312101 & $08-28-86$ & -- & -- & -- & -- & 60 & -- & -- & -- \\
\hline DR10- & 401732107312201 & $08-28-86$ & -- & -- & -- & - & 140 & $-\infty$ & - & -- \\
\hline DR11 & 401733107312201 & $08-28-86$ & -- & -- & $\cdots$ & - & 70 & 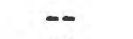 & - & -- \\
\hline Deep Rock & 09249455 & $09-29-85$ & - & $<0.01$ & $<1$ & 120 & 70 & $<1$ & 22 & 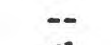 \\
\hline Gulch near & & $01-08-86$ & 0.03 & -- & $<1$ & 130 & 60 & 20 & 17 & $<1$ \\
\hline Hamilton & & $05-07-86$ & - & 0.03 & 1 & 69 & 30 & $<1$ & 24 & $<1$ \\
\hline \multirow[t]{3}{*}{ (DR13) } & & $07-30-86$ & -- & 0.01 & $<1$ & 130 & 70 & $<1$ & 25 & $<5$ \\
\hline & & $08-28-86$ & -- & - & - & -- & 80 & -- & -- & -- \\
\hline & & $10-07-86$ & $\cdots$ & $<0.01$ & $<1$ & 96 & 60 & 1 & 51 & $<5$ \\
\hline W2- & 401650107291501 & $08-27-86$ & -- & - & -- & -- & 90 & -- & -- & -- \\
\hline W5 & 401734107302801 & $08-27-86$ & - & $\ldots$ & -- & - & 90 & -- & -- & -- \\
\hline \multirow{5}{*}{$\begin{array}{l}\text { Waddle Creek } \\
\text { near Pagoda } \\
\text { (W8) }\end{array}$} & 09249450 & $01-08-86$ & 0.04 & - & $<1$ & 68 & 70 & $<1$ & 30 & $<1$ \\
\hline & & $05-08-86$ & -- & 0.01 & 1 & 68 & 50 & $<1$ & 17 & $<1$ \\
\hline & & $07-30-86$ & -- & 0.02 & $<1$ & 68 & 80 & $<1$ & 29 & $<5$ \\
\hline & & $08-27-86$ & - & - & -- & 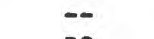 & 90 & -- & 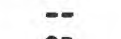 & - \\
\hline & & $10-07-86$ & - & $<0.01$ & $<1$ & 50 & 70 & 1 & 25 & $<5$ \\
\hline \multirow[t]{2}{*}{ W10-........ } & 401753107305701 & $09-29-85$ & -- & 0.01 & $<1$ & 78 & 80 & 3 & 14 & -- \\
\hline & & $08-27-86$ & -- & - & -- & -- & 90 & -- & -- & - \\
\hline W12- & 401807107310501 & $08-27-86$ & - & $\cdots$ & -- & -- & 80 & -- & - & $\rightarrow$ \\
\hline W13-n-n- & 401816107311601 & $08-27-86$ & - & -- & $-\infty$ & -- & 90 & -- & -- & - \\
\hline W15 (Hart & 401847107314601 & $08-27-86$ & -- & - & $\cdots$ & $-\infty$ & 130 & $-\infty$ & -- & - \\
\hline $\begin{array}{l}\text { Gulch near } \\
\text { mouth) }\end{array}$ & & $10-07-86$ & -- & $<0.01$ & $<1$ & 82 & 80 & $<1$ & 14 & $<5$ \\
\hline W17-non & 402000107315601 & $08-27-86$ & - & $<0.01$ & $<1$ & 70 & 100 & $<1$ & 5 & $<5$ \\
\hline $\begin{array}{l}\text { North Fork } \\
\text { Deer Creek }\end{array}$ & 401532107340401 & $10-07-86$ & - & 0.01 & $<1$ & 100 & 50 & $<1$ & 13 & $<5$ \\
\hline HSP1 $1 \ldots$ & 401529107273501 & $08-06-86$ & -- & -- & -- & -- & 40 & -- & -- & -- \\
\hline $\begin{array}{l}\text { Station } \\
\text { name }\end{array}$ & Station number & $\begin{array}{l}\text { Date } \\
\text { of } \\
\text { sample }\end{array}$ & $\begin{array}{c}\text { Lithium, } \\
\text { dis- } \\
\text { solved } \\
\left(\mu_{8} / \mathrm{L}\right. \\
\text { as } \mathrm{Li})\end{array}$ & $\begin{array}{c}\text { Manga- } \\
\text { nese, } \\
\text { dis- } \\
\text { solved } \\
\left(\mu_{8} / L\right. \\
\text { as Mn })\end{array}$ & $\begin{array}{l}\text { Molyb- } \\
\text { denum, } \\
\text { dis- } \\
\text { solved } \\
(\mu g / L \\
\text { as Mo) }\end{array}$ & $\begin{array}{l}\text { Nickel, } \\
\text { dis- } \\
\text { solved } \\
(\mu g / L \\
\text { as } N i)\end{array}$ & $\begin{array}{l}\text { Sele- } \\
\text { nium, } \\
\text { dis- } \\
\text { solved } \\
\left(\mu_{8} / L\right. \\
\text { as } \mathrm{Se})\end{array}$ & $\begin{array}{l}\text { Stron- } \\
\text { tium, } \\
\text { dis- } \\
\text { solved } \\
(\mu g / L \\
\text { as } S r)\end{array}$ & $\begin{array}{l}\text { Vana- } \\
\text { dium, } \\
\text { dis- } \\
\text { solved } \\
\left(\mu_{8} / L\right. \\
\text { as V) }\end{array}$ & $\begin{array}{l}\text { Zinc, } \\
\text { dis- } \\
\text { solved } \\
\left(\mu_{8} / L\right. \\
\text { as } \mathrm{Zn})\end{array}$ \\
\hline DR1- & 401608107304601 & $08-28-86$ & -- & -- & -- & - & $-\infty$ & 190 & -- & $-\infty$ \\
\hline DR9 - & 401731107312101 & $08-28-86$ & $\cdots$ & -- & - & - & $-\infty$ & 410 & $-\infty$ & $-\infty$ \\
\hline DR10 & 401732107312201 & $08-28-86$ & -- & -- & - & - & -- & 710 & -- & - \\
\hline DR11- & 401733107312201 & $08-28-86$ & -- & -- & - & - & - & 470 & - & -- \\
\hline Deep Rock & 09249455 & $09-29-85$ & 29 & 35 & 1 & 8 & - & 530 & - & 8 \\
\hline Gulch near & & $01-08-86$ & 31 & 66 & 1 & 9 & 1 & 610 & 1 & 14 \\
\hline Hamilton & & $05-07-86$ & 11 & 23 & 1 & $<1$ & 1 & 190 & 2 & 6 \\
\hline \multirow[t]{3}{*}{ (DR13) } & & $07-30-86$ & 21 & 35 & $<1$ & 1 & $<1$ & 520 & 1 & 6 \\
\hline & & $08-28-86$ & -- & -- & -- & - & -- & 470 & - & -- \\
\hline & & $10-07-86$ & 28 & 55 & 11 & 1 & $<1$ & 430 & 2 & $<3$ \\
\hline W2- & 401650107291501 & $08-27-86$ & $\cdots$ & -- & -- & -- & -- & 540 & - & -- \\
\hline 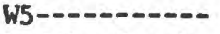 & 401734107302801 & $08-27-86$ & $-\infty$ & -- & -- & -- & - & 860 & -- & -- \\
\hline \multirow{5}{*}{$\begin{array}{l}\text { Waddle Creek } \\
\text { near Pagoda } \\
\text { (W8) }\end{array}$} & 09249450 & $01-08-86$ & 40 & 45 & $<1$ & $<1$ & 2 & 970 & $<1$ & 48 \\
\hline & & $05-08-86$ & 30 & 30 & 1 & 3 & 2 & 540 & 1 & 5 \\
\hline & & $07-30-86$ & 34 & 19 & $<1$ & 1 & 1 & 890 & 2 & 7 \\
\hline & & $08-27-86$ & -- & - & -- & - & -- & 900 & -- & -- \\
\hline & & $10-07-86$ & 45 & 32 & 8 & 1 & 1 & 850 & 1 & 11 \\
\hline \multirow[t]{2}{*}{ W10 } & 401753107305701 & $09-29-85$ & 40 & 15 & $<1$ & 3 & $-\infty$ & 900 & -- & 11 \\
\hline & & $08-27-86$ & $\cdots$ & -- & -- & - & -- & 900 & - & -- \\
\hline W12-n-m-non & 401807107310501 & $08-27-86$ & -- & - & - & -- & -- & 590 & -- & -- \\
\hline W13-an & 401816107311601 & $08-27-86$ & - & -- & - & - & - & 630 & -- & - \\
\hline W15 (Hart & 401847107314601 & $08-27-86$ & -- & -- & -- & - & - & 900 & -- & -- \\
\hline $\begin{array}{l}\text { Gulch near } \\
\text { mouth) }\end{array}$ & & $10-07-86$ & 41 & 13 & 9 & $<1$ & 2 & 880 & $<1$ & 10 \\
\hline W17- & 402000107315601 & $08-27-86$ & 47 & 6 & $<1$ & 2 & 2 & 870 & 1 & 10 \\
\hline $\begin{array}{l}\text { North Fork } \\
\text { Deer Creek }\end{array}$ & 401532107340401 & $10-07-86$ & 25 & 5 & 5 & 1 & 1 & 880 & 1 & 12 \\
\hline HSP1 $1 \ldots$ & 401529107273501 & $08-06-86$ & - & - & $\ldots$ & -- & - & 53 & -- & -- \\
\hline
\end{tabular}

